\section{To: (Receiving Organization) \\ DISTRIBUTION \\ 5. Pro]./Prog./Dept./Div.: \\ INTERIM STABILIZATION}

8. Originator Remarks:

ATTACHED IS A TEST REPORT FOR THE ACCEPTANCE TESTING OF PUMPING AND INSTRUMENTATION CONTROL SKID " $K$ ".

11. Receiver Remarks:

NONE

3. From: (Originating Organization)
INTERIM STABILIZATION
$\begin{aligned} & \text { 6. Design Authorly Design Agent/Cog. Engr.: } \\ & \text { W. F. ZUROFF }\end{aligned}$

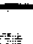

4. Related EDT No.:
N/A
7. Purchase Order No.:
N/A

9. Equip./Component No.:

$\mathrm{N} / \mathrm{A}$

10. System/Bidg./Facility:

241-G

12. Major Assm. Dwg. No.:

$\mathrm{N} / \mathrm{A}$

13. Permit/Permit Application No.:

N/A

14. Required Response Date:

$09 / 13 / 99$

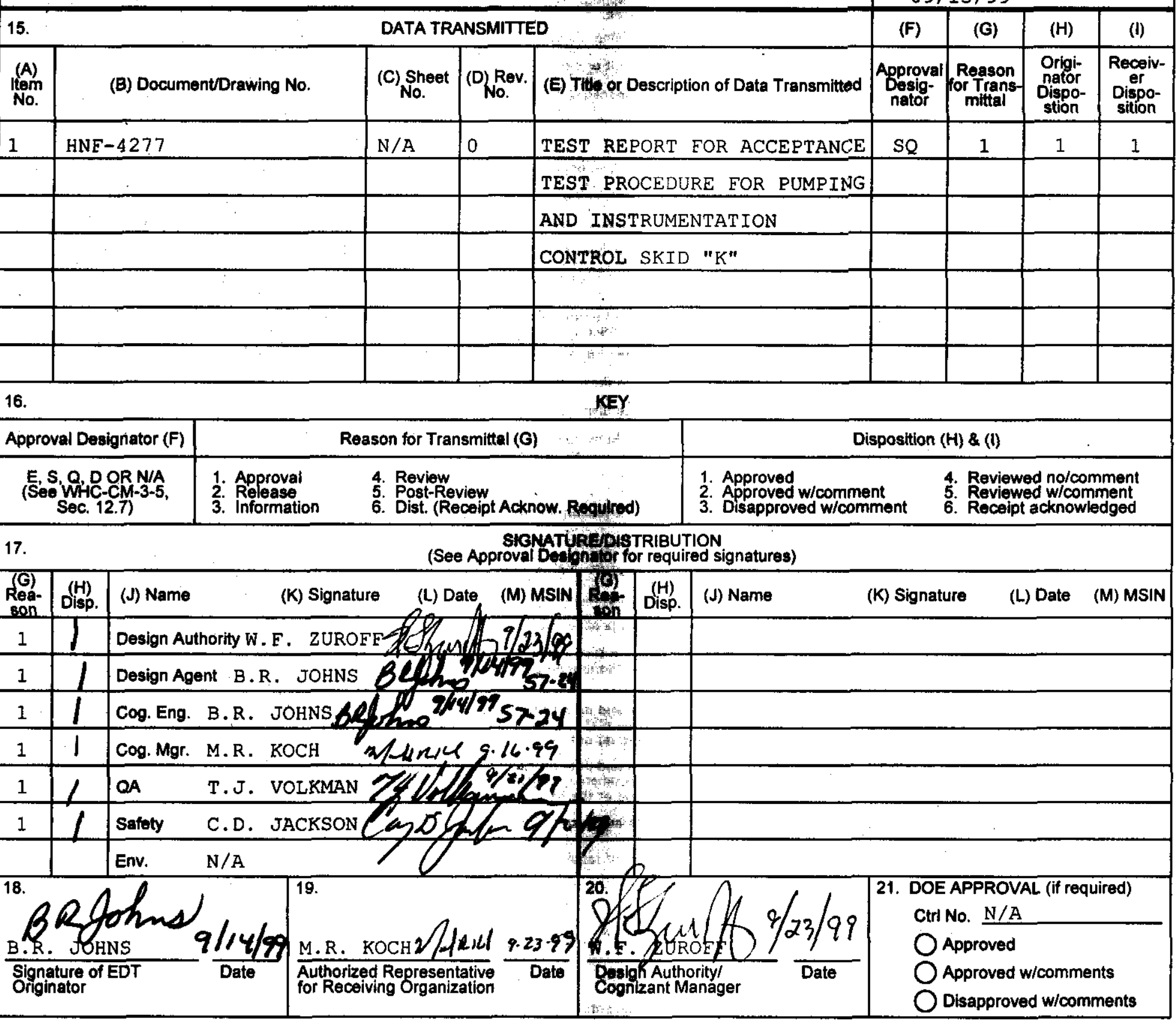




\title{
TEST REPORT FOR ACCEPTANCE TEST PROCEDURE FOR PUMPING AND INSTRUMENTATION CONTROL SKID "K"
}

B. R. JOHNS

COGEMA ENGINEERING CORPORATION

Richland, WA 99352

U.S. Department of Energy Contract DE-AC06-96RL13200

\author{
EDT/ECN: 626398 \\ UC: \\ Org Code: $74 \mathrm{D} 00$ \\ Charge Code: 103361 \\ B\&R Code: EW3120071 \\ Total Pages: 128
}

Key Words: PICS, SALT WELL, SKID, INTERIM STABILIZATION, TESTING

Abstract:

This is a Test Report for Acceptance Test Procedure (ATP) HNF-4276.

This test report provides the results of the inspection and testing of the new Pumping and Instrumentation Control (PIC) skid designed as " $K$ ". The ATP was successfully completed. A copy of the completed ATP is in the Appendix of this document.

TRADEMARK DISCLAMMER. Reterence herein to any speclfic commercial product, process, or service by trade name, trademark, manufacturer, or otherwise, does not necesserilly constitute or imply its endorsement, recommendation, or favoring by the United States Government or any agency thereof or its contractors or subcontractors.

Printed in the United States of America. To obtain copies of this document, contact: Document Control Services, P.O. Box 950, Mailstop H6-08, Richland WA 99352, Phone (509) 372-2420; Fax (509) 376-4989.
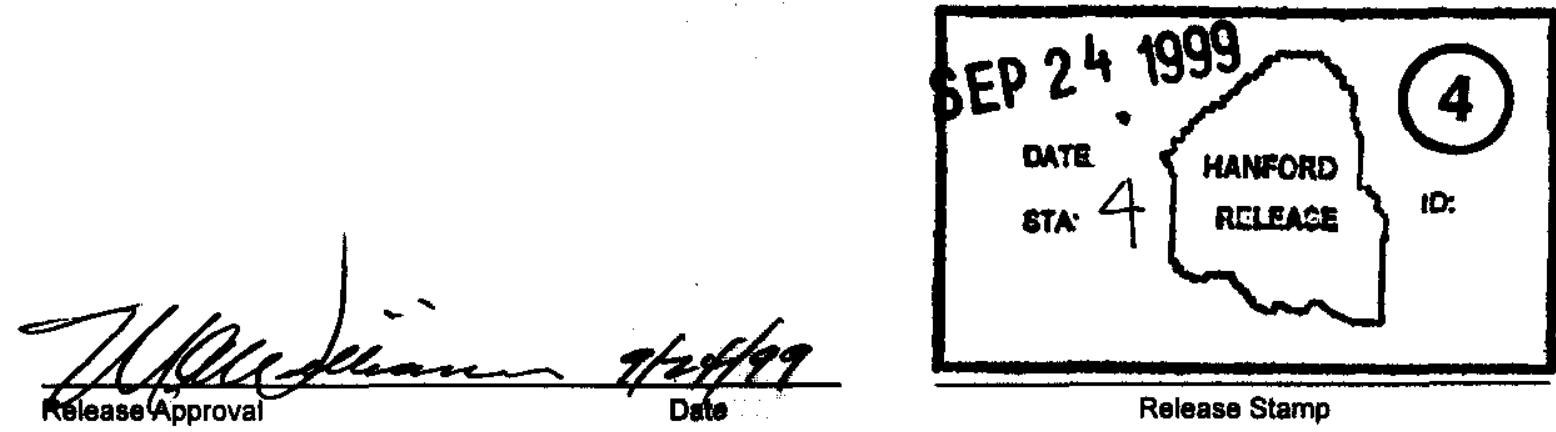

Release Stamp 

PUMPING AND INSTRUMENTATION CONTROL SKID "K"

\subsection{INTRODUCTION}

This test report provides the results from the performance of Acceptance Test Procedure (ATP) HNF-4276, for Pumping and Instrumentation Control (PIC) skid "K". The ATP verifies the proper construction of the PIC skid "K" by Site Fabrication Services along with proper programming of the Programmable Logic Controller (PLC) and the Operations Control Station (OCS) computer by engineering. New PIC skid "K" will be used for the pumping of tank U-103. A copy of the actual test results is in the Appendix.

\subsection{DESCRIPTION OF TEST}

The test was divided into two parts. Part I of the testing was performed at the Site Fabrication Services location. Part II was performed at the Interim Stabilization maintenance shop.

Part I of the ATP ensured the PIC skid was assembled and functioned as per the design drawings. Inputs to the skid were simulated to ensure proper equipment connections and wiring.

Part II of the ATP ensured the software programs and the interfaces to the equipment outside the PIC skid were correct. The PIC skid was connected to the jet pump, jumper and flush line assemblies. A Flammable Gas Monitor (FGM) and leak detector probes were connected to the PIC skid to ensure proper functioning of these items. Dilution tank connections were simulated since the tank and the controls were not available. The U-farm computer was connected to the PLC to ensure proper communication between the two devices.

The ATP document provided detailed instructions for each test step and space for recording the data and signoffs. A copy of all the test results including exceptions is in the Appendix.

\subsection{TEST METHOD AND TEST EQUIPMENT}

The ATP detailed the test methods and the test equipment to be used for testing. Test equipment identification and calibration dates are recorded on the ATP data sheets. Quality Control and Engineering witnessed the performance of the ATP. 
HNF-4277

REVISION 0

\subsection{TEST RESULTS}

The ATP was successfully completed. Discrepancies in the test procedure were listed as exceptions. All the exceptions identified became part of the ATP and are in the Appendix along with the ATP results. All exceptions were reviewed, resolved and signed off as closed for this ATP.

A National Electrical Code (NEC) inspection was performed as part of the ATP. The NEC inspector accepted the electrical power portion of the skid and placed a blue acceptance sticker on the distribution panel. A Pressure Vessel inspector checked the water and air compressor tanks along with the associated relief valves. The installation of these tanks was acceptable. A copy of the NEC and Pressure Vessel inspection reports are in the Appendix of this document.

\subsection{CONCLUSIONS AND RECOMMENDATIONS}

The PIC skid is found to be ready for field operation. All exceptions were resolved. An Operational Test Procedure (OTP) will be performed after the skid is set up in the field.

\subsection{REFERENCES}

HNF-4276, REVISION 0-A, ACCEPTANCE TEST PROCEURE FOR PUMPING AND INSTRUMENTATION CONTROL SKIDS, Lockheed Martin Hanford Corporation, Richland, Washington.

2H9903385, Site Fabrication Services work package.

WS-99-0474, Interim Stabilization work package. 


\subsection{APPENDIX}

Copy of ATP, HNF-4276, revision 0-A.

NEC Inspection Report

Pressure Vessel Inspection Report 


\subsection{PREREQUISITES}

NOTE - Equipment shall be available before the step associated with that piece of equipment.

\subsection{DRAWING VERIFICATION}

A check of the constructed skid is to be compared to either the red-lined drawings or the final unreleased skid drawings. Engineering and Quality Control shall verify the accuracy of the essential and support drawings. Engineering shall determine a resolution for all discrepancies by either correcting the drawings or changing the equipment.

The following areas on the drawings are to be verified.

- Wire terminations and labeling, $\mathrm{H}-14-103530$, sheets 7 through $12, \mathrm{H}-14-103533$, sheet 5.

- $\quad$ Panel board arrangement, $\mathrm{H}-14-103536$

- Correctness of flow diagram logic, $\mathrm{H}-14-103535$ and $\mathrm{H}-14-103530$, sheet 5 .

Drawing verification completed and how all discrepancies will be resolved. *Final drawing release is not required to continue with the ATP.)

* Soe

exreption 1 on Exception Log (page 224)

Cognizant ERgineer

* Kor wiltigy $7 / 21 / 99$

Quality Control

Date 


\subsection{THIRD PARTY INSPECTION}

A third party inspection is required for the air compressor, the air receiver tank and relief valves located in the air compressor cabinet. The inspection is to verify that the equipment meets National Codes for pressure vessels. This inspection will be performed by an outside certified inspector. (This needs to be completed prior to checking the air compressor and water systems.)

Third party inspection report received. (The ATP can continue before the report is received, but must be received prior to performing sections 5.6.)

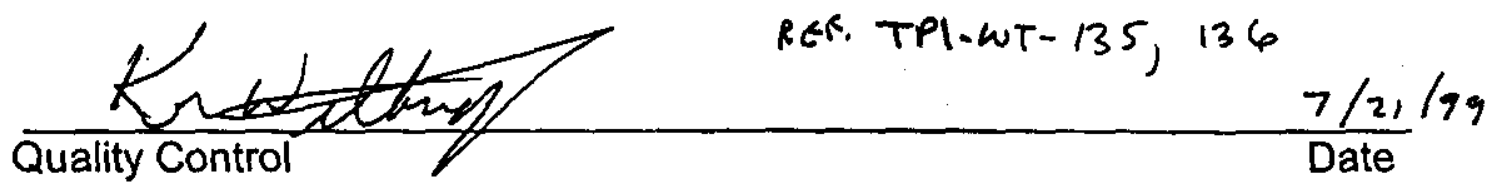

\subsection{NATIONAL ELECTRICAL CODE (NEC) INSPECTION}

- An NEC inspection shall be performed to verify compliance to NFPA 70, latest . version.

- Areas in particular to be inspected are $480 \mathrm{vac}$ and $120 \mathrm{vac}$ wiring and grounding.

- An NEC inspection sticker is to be placed inside the panel board door upon the NEC inspector's acceptance of the electrical portion of the skid.

The NEC inspection performed and an NEC inspection sticker has been placed on the panel board door. (This needs to be completed prior to the Section 5 functional checks.)

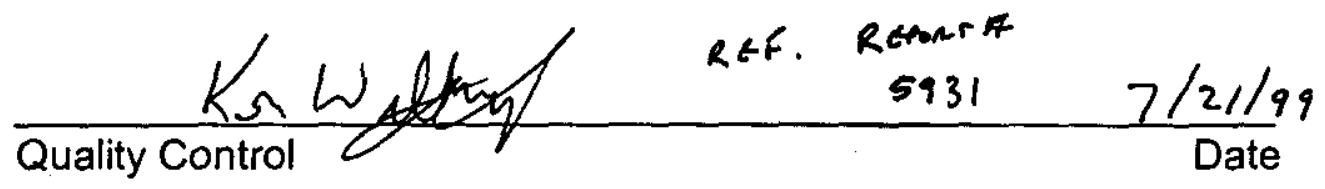

\subsection{SUPPLIES}

4.4.1 The following supplies shall be available at the work place:

- Volt/ohm meter (VOM): Portable, $0-600$ volts ac, $\pm 2 \%$ accuracy.

Calibration No. $819 \cdot 45-08-018$ Expiration Date $11 / 7 / 99$ QC BJE 7.26.99

- Transmation current (milliamp) simulator or equivalent

Calibration No. 812-13-20.013 Expiration Date 10/99_ QC KW $1 / 4 / 99$

- Manometer - minimum range 0-500" water gauge. Must have a read out of variable test pressure.

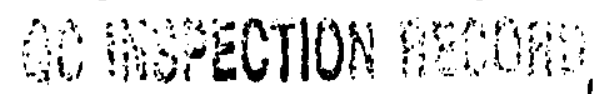

Calibration No. 820.35-40-004 Expiration Date QC KW $8 / 1 / 99$ 
- Manometer - minimum range 0-62" water gauge. Must have a read out of variable
test pressure. PartII tisting $>$ 820-35-40-004
$7 / 7 / 00$
QC KN 9/8/99
Calibration No. $\frac{820 \cdot 35 \cdot 40-004}{* 819-35-40 \cdot 001}$
Expiration Date
$\frac{7 / 7 / 00}{4 / 7 / 00}$

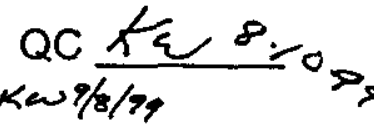
- Jumper Test Assembly PI-2 (suction) pressure gauge (for Part II) Kw $9 / 8 / 99$

$$
\text { 817-35-40-038 10-2-99 }
$$

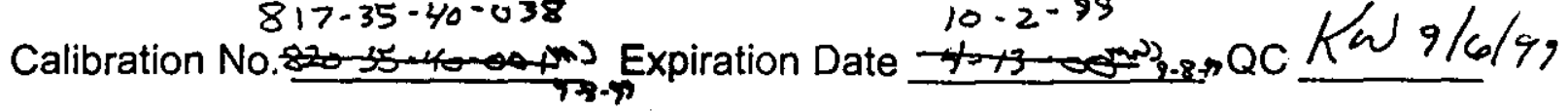

- Jumper Test Assembly PI-1 (discharge) pressure gauge (for Part II)

Calibration No.817-35-40.042 Expiration Date 1-500 QC Kw $1 / 6 / 99$

- Saltwell Jet pump Jumper (see H-14-100725 Sheet 18) (for Part II)

- Rotameter or Flowmeter with an accuracy of $0.05 \mathrm{gpm}$, a range at least of 0 to 4 gpm (for Part II)

- Jumper Test Assembly (for Part II) 0.10

$$
\text { bif } 914199
$$

- $\quad 480 V 3$ Phase Power Source

- Controlotron 995T Control and Display Unit

- Selector switch (2 each) with one NO and one NC contact

NOTE -Test sections may commence prior to assembly of all test equipment. Engineer is responsible to assure all equipment necessary for a given section is available.
Exception 5 (Addad megohm)

4.4.2 The following conditions must be met prior to the performance of the test section indicated:

4.4.2.1 The Jet Pump Jumper and Jumper assembly have been placed on the pump recirculation apparatus prior to performing Part II.

4.4.2.2 The Pumping and Instrumentation Control Skid water tank and run-in tank

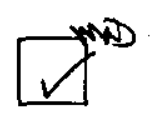

\footnotetext{
have been adequately filled for testing prior to performing section 5.6.
}

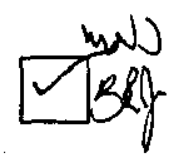

4.4.2.3 The Jet Pump Jumper AND Jumper Assembly have been electrically AND pneumatically connected to the Pumping and Instrumentation Control Skid prior to performing Part II. Reference H-14-103071. see exaytronizal ag 23, 
4.4.2.4 A pre-job safety meeting has been held before performing each section of this procedure. $7 / 26 / 99$ bof $9.6-99 \mathrm{mw}$

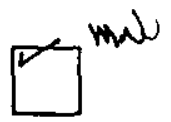

4.4.2.5 The Pumping and Instrumentation Control Skid has been grounded in preparation for shop testing.

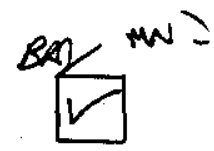

4.4.2.6 Test gauges AND rotameter have been installed in correct locations as indicated by the Engineer prior to performing sections requiring test gauges and rotameter.

- 4.4.2.7 Ensure the following Pumping and Instrumentation Control Skid Valves are OPEN prior to starting this ATP.

$\checkmark \underline{ }$ SALW-V-6035K (equalizing) $\simeq$ SALW-V-6036K (equaling)

PUE 7.26 .99

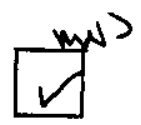

- 4.4.2.8 ENSURE the following Pumping and Instrumentation Control Skid valves are CLOSED prior to starting this Acceptance Test Procedure:

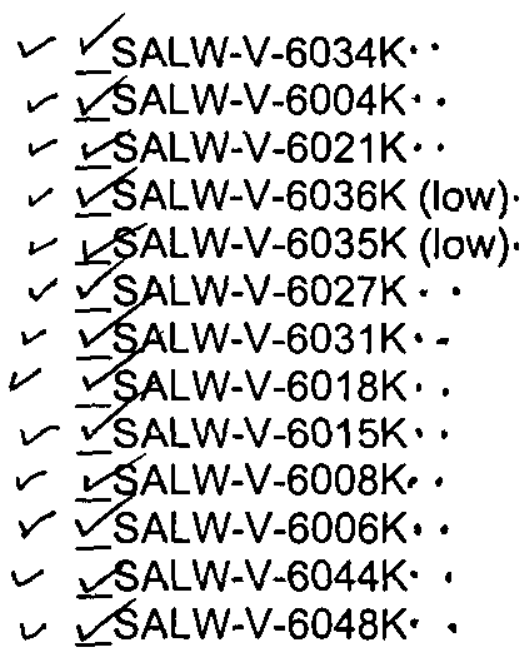

$r$ ISALW-V-6026K. '

$\checkmark$ ISALW-V-6002K..

$\checkmark$ SALW-V-6020K SALW-V-6035K (hi).. SALW-V-6019K. VSALW-V-6028K. . $\checkmark$ SALW-V-6030K. 。 $\checkmark$ SALW-V-6017K. -SALW-V-6014K. $\checkmark$ SALW-V-6011K. $\checkmark$ SALW-V-6007K。 $\checkmark$-SALW-V-6046K. . SALW-V-6049K. .

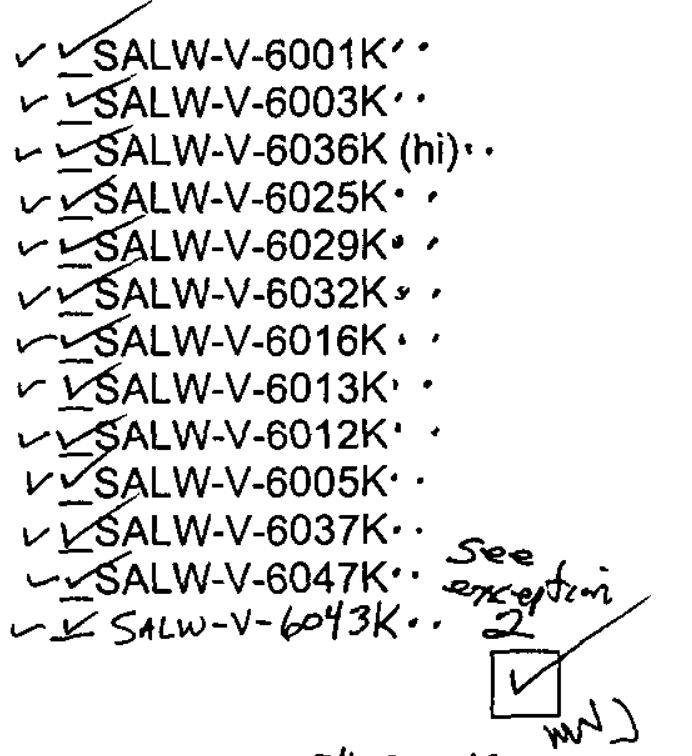

Pet 722.94

\section{Bu}




\section{HNF-4277 \\ REVISION 0}

4.4.2.9 ENSURE the following Pumping and Instrumentation Control Skid circuit disconnects and breakers are OPEN (OFF) prior to starting this Acceptance Test Procedure. Refer to $\mathrm{H}-2-85327$, Sheet 7 for circuit breakers.

$\sim \checkmark$ SALW-DS-6002K $\checkmark$ VSALW-DS-6003K $\checkmark$ VSALW-DS-6004K

$\checkmark \unrhd$ SALW-DS-6005K

NOTE - The following breakers are located in SALW-DP-6001K.

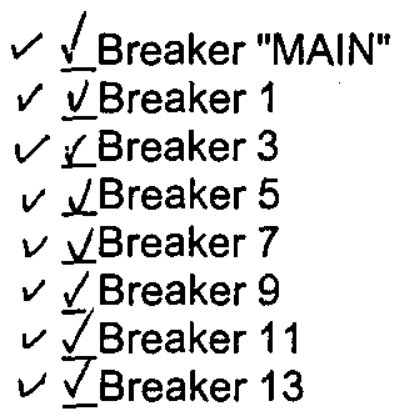

$\checkmark \checkmark$ Breaker 2

$\checkmark$ JBreaker 4

$\checkmark \checkmark$ Breaker 6

$\checkmark$ IBreaker 8

$\checkmark \checkmark$ Breaker 10

$\checkmark \sqrt{ }$ Breaker 12

$\checkmark \underline{\checkmark}$ Breaker 14

PIE 7.26 .99

4.4.2.10 All personnel initialing or signing this procedure must also enter signature/initials on the PROCEDURE PERFORMER SIGNATURE SHEET on the last page of this document. 


\subsection{PROCEDURE}

NOTE - $\quad$ All personnel performing this procedure, who will be initialing and signing the procedure, shall enter their printed name, signature and initials on the PROCEDURE PERFORMER SIGNATURE SHEET.

NOTE: Verify Prerequisites completed for Part I.

\subsection{CONTINUITY CHECKS}

Continuity checks shall be performed with a calibrated VOM. Perform the checks as identified below. Readings are to be less than $1 \mathrm{ohm}$. Record readings on the line provided. Out of tolerance readings must be corrected and retested before going to the next section.

5.1.1 Crouse-Hinds plug to line side of main disconnect switch (SALW-DS-6002K). Check all three phases and ground wire. Red.5 $\Omega$ Yellow. $5 \Omega$ bloe. $4 \Omega$ Gnd.4 $\Omega$

5.1.2 Load side of main disconnect switch (SALW-DS-6002K) to line side gf transformer

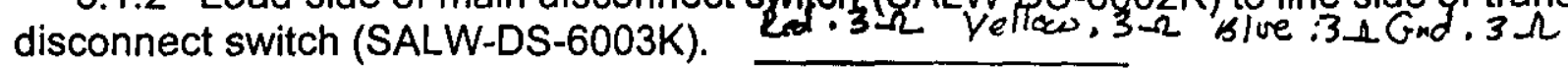

5.1.3 Load side of main disconnect switch (SALW-DS-6002K) to line side of jet pump

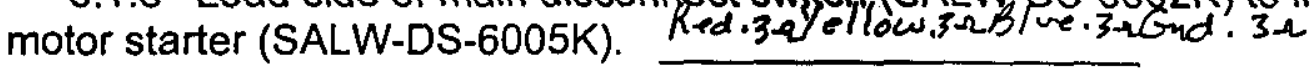

5.1.4 Load side of main disconnect switch (SALW-DS-6002K) to line side of air compressor motor starter (SALW-DS-6004K). Red. $3 \Omega$ yellow 4 olve. 4 Gnd. 4
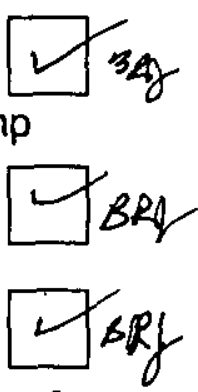

5.1.5 Load side of transformer disconnect switch.(SALW-DS-6003K) to primary side of transformer. $.5 \Omega$ Through transfonmer primiory Coil.

5.1.6 Secondary side of transformer to panel board (SALW-DP-6001K)main breaker.

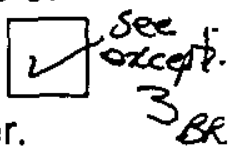

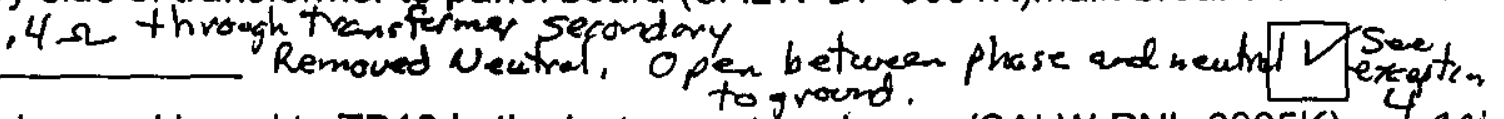

5.1.7 Circuit \#3 in panel board to TB10 in the instrument enclosure (SALW-PNL-6005K). ${ }^{4} B R$ .8

5.1.8 Circuit \#5 in panel board to TB13 in the instrument enclosure (SALW-PNL-6005K).

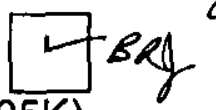

$$
.8
$$

5.1.9 Circuit \#12 in panel board to TB13 in the instrument enclosure (SALW-PNL-6005K). .6

5.1.10 Circuit \#6 in panel board to safe side TB in the jntrinsic safe panel (SALW-PNL$6006 \mathrm{~K})$.

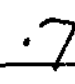

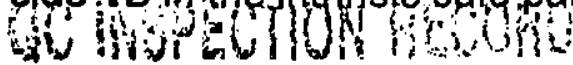

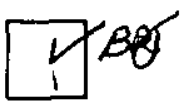



5.1.11 Circuit \#1 in panel board to TB in the FGM power junction box. $8 \Omega$

5.1.12 Circuit \#11 in panel board to TB in the FGM power junction box. , $8 \simeq$

5.1.13 Circuit \#13 in panel board to TB in the FGM power junction box. $18 \Omega$

5.1.14 Circuit \#14 in panel board to TB in the FGM power junction box. $.7 \Omega$

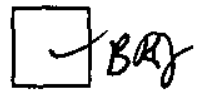

5.1.15 Circuit \#10 in panel board to TB in the FGM heat trace splice box. $17 \Omega$

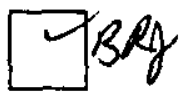

5.1.16 Circuit \#2 in panel board to TB in the FGM heat trace splice box. 41

5.1.17 Circuit \#7 in panel board to receptacles in the WFIE cabinet (SALW-PNL-6002K). $.4 \Omega$

5.1.18 Circuit \#9 in panel board to receptacle below panel board. $.4 \Omega$

5.1.19 Circuit \#4 in panel board to air compressor cabinet (SALW-PNL-6001K).

$$
.4 \Omega
$$

5.1.20 Circuit \#8 in panel board to water cabinet (SALW-PNL-6003K).

$$
.4 \Omega
$$

Section 5.1 completed and all readings within tolerance.

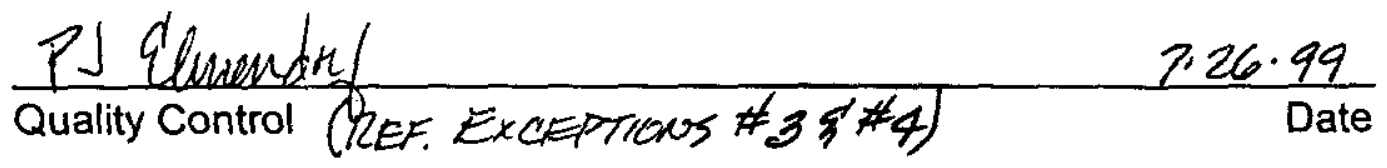




\subsection{MEGGERING OF POWER WIRES}

The power wires shall be check for resistance to ground and phase to phase. A 500 volt megger shall be used for this check. Minimum acceptable readings are greater than 1 megohm. Test the circuits listed below. Record readings on the lines provided. Out of tolerance readings must be corrected and retested before going to the next section. Exception 5 (Added megohm)

5.2.1 Each of the three phases on the main power plug to ground and phase to phase. (Main disconnect switch (SALW-DS-6002K) is opened.)

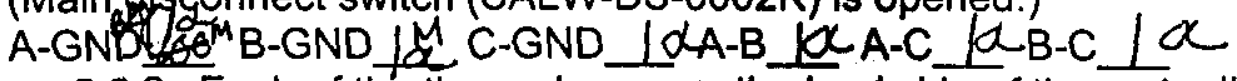

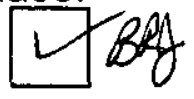

5.2.2 Each of the three phases on the load side of the main disconnect switch (SALW-DS$6002 \mathrm{~K}$ ) to ground and phase to phase. (The transformer disconnect switch (SALW-DS-6003K) and the two motor starters (SALW-DS-6004K) (SALW-DS-6005K) are opened.) A-GND $\propto$ B-GND $1700^{\circ} \mathrm{C}-G N D \propto$ A-B $1900 / \mathrm{AA} C \mathrm{\alpha}$ B-C $\alpha$

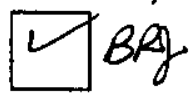

5.2.3 Each of the two phases on the load side of the transformer disconnect switch (SALW-DS-6003K) to ground. Exception 6 $A-G N D \propto B-G N D \propto A-B N / A$

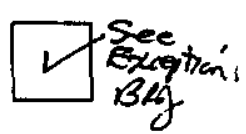

5.2.4 Each of the two hot wires on the line side of the 100 ampere main breaker in the panel board (SALW-DP-6001K) to ground. (The 100 ampere main breaker to pe opened.). A-GNDI600 B-GND $\propto$ A-B NIA Exreption 6 Neatral (disconnected) to gnd. $\underline{\alpha}$

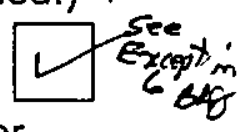

5.2.5 Each of the three phases on the load side of the air compressor motor starter (SALW-DS-6004K) to ground.

5.2.6 Each of the 14 circuits in the panel board to ground on the load fide of each breaker. The breakers are to be opened and the hot wire disconnected from the ground fault type breakers and receptacles(This is to prevent damage to the ground fault sensor in the breakers.). Disconnect all loads on each circuit by removing a down stream fuse or lift the hot $5 \times$ cas. wire. 1-GND $\propto$ 2-GND $\propto$ 3-GND $\propto$ 4-GND $\propto$ 5-GND $\alpha$ 6-GND $\propto$ 7-GND $\propto$ 8-GND $\propto$ 9-GND $\alpha$ 10-GND $\alpha$ 11-GND $\propto \overline{12-G N D \_}$

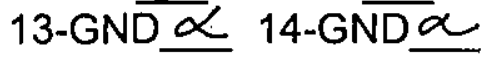

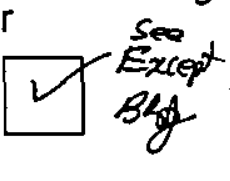

5.2.7 Reconnect all wires and reinstall fuses.

Section 5.2 completed and all readings within tolerance.

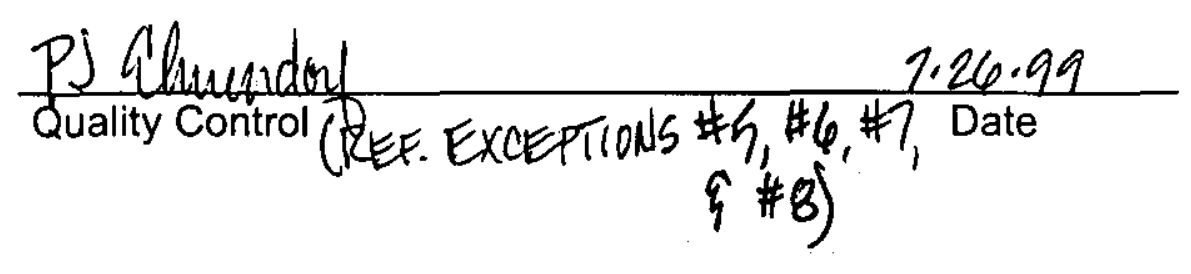

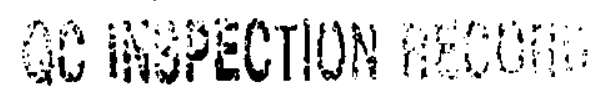




\subsection{ELECTRICAL POWER CHECKS}

The voltage checks are to verify proper voltages throughout the skid at specific termination points. Voltages checked are $480 \mathrm{vac}, 3$ phase; $120 \mathrm{vac}$, single phase; and $24 \mathrm{vdc}$. Out of tolerance readings must be corrected when found before going to the next step in this section.

5.3.1 Visually verify that all electrical connections are completed. Wires lifted during the megger checks are to be reconnected.

5.3.2 Open all switches and breakers and pull the fourfuses in the instrument cabinet (SALW-PNL-6005K).

six Exception'

5.3.3 Visually verify that all the fuses are in the two safety switches (SALW-DS-6002K) (SALW-DS-6003K) and motor starters (SALW-DS-6004K) (SALW-DS-6005K) including the control transformers.

5.3.4 Connect the main power plug on the skid to a three phase, $480 \mathrm{vac}$ power source. Source to be protected by no greater than 30 amperes over current protection.

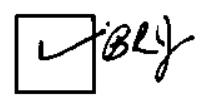

5.3.5 Turn ON the power source to the skid.

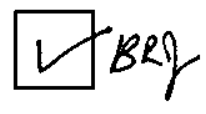

5.3.6 Verify 480vac on the line side of the main disconnect switch (SALW-DS-6002K).

Record the voltage. $\frac{480 A-B}{484 A-C} 480 \mathrm{vac}+10 \mathrm{vac} / 20 \mathrm{vac}$.

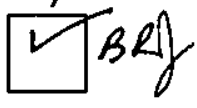

5.3.7 Close the main disconnect switch (SALW-DS-6002K).

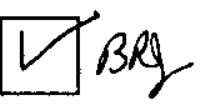

5.3.8 Check for $480 \mathrm{vac}+10 \mathrm{vac} /-20 \mathrm{vac}$ at the following three locations (entries 5.3.9, 5.3.10 and 5.3.11). Record voltage reading on the line provided.

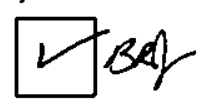

5.3.9 Line side of the transformer disconnect switch (SALW-DS-6002K).

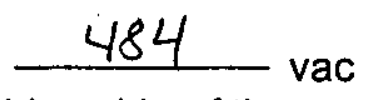

5.3.10 Line side of the pump motor starter (SALW-DS-6005K). A-B $A-C$ $480 \quad 483$ $483 B-C$

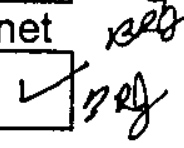


5.3.13 Close the transformer disconnect switch (SALW-DS-6003K).

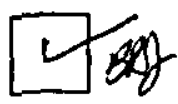

5.3.14 Check for $240 \mathrm{vac}+10 /-20$ at the line side of the main breaker. Record voltage. 242 vac

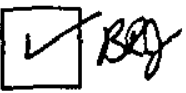

5.3.15 Open the transformer disconnect switch (SALW-DS-6003K).

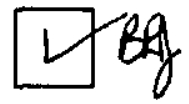

5.3.16 Replace the dead front on the panel board (SALW-DP-6001K).

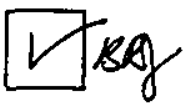

5.3.17 Close the transformer disconnect switch (SALW-DS-6003K).

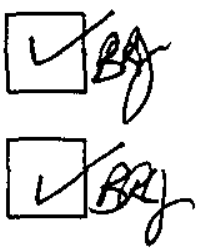

5.3.19 Check for $120 \mathrm{vac}+/$-10vac at the following locations (entries 5.3.20 through 5.3.45). Record the voltage reading on the line provided.

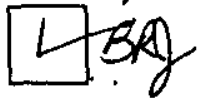

5.3.20 Close breaker \#1. Measure voltage at the terminal board in the FGM junction box on the outside of the WFIE cabinet (SALW-PNL-6002K).

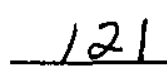

vac

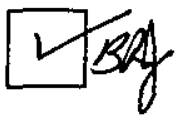

5.3.21 Open breaker \#1. Measure zero voltage at the terminal board in the FGM junction box on the outside of the WFIE cabinet (SALW-PNL-6002K).
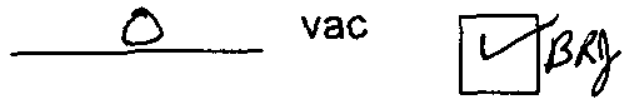

5.3.22 Close breaker \#2. Measure voltage at the terminal board in the FGM splice box on the outside of the WFIE cabinet (SALW-PNL-6002K). 121 vac

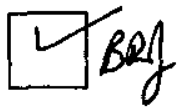

5.3.23 Open breaker \#2. Measure zero voltage at the terminal board in the FGM splice box on the outside of the WFIE cabinet (SALW-PNL-6002K).

O vac

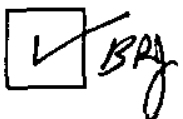

5.3.24 Close breaker \#10. Measure voltage at the terminal board in the FGM splice box on the outside of the WFIE cabinet (SALW-PNL-6002K). 121 vac
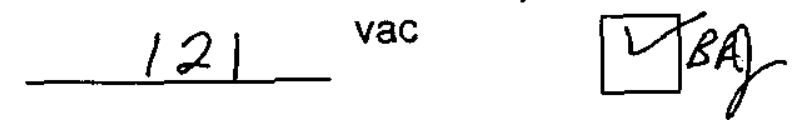

5.3.25 Open breaker \#10. Measure zero voltage at the terminal board in the FGM splice box on the outside of the WFIE cabinet (SALW-PNL-6002K). vac

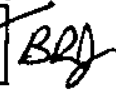

5.3.26 Close breaker \#11. Measure voltage at the terminal board in the FGM junction box on the outside of the WFIE cabinet (SALW-PNL-6002K).

\section{io}

121 vac

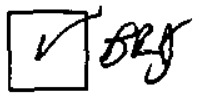


5.3.27 Open breaker \#11. Measure zero voltage at the terminal board in the FGM junction box on the outside of the WFIE cabinet (SALW-PNL-6002K).
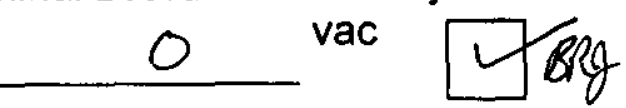

5.3.28 Close breaker \#13. Measure voltage at the terminal board in the FGM junction box on the outside of the WFIE cabinet (SALW-PNL-6002K). $|2|$ vac

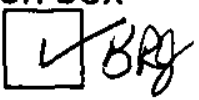

5.3.29 Open breaker \#13. Measure zero voltage at the terminal board in the FGM junction box on the outside of the WFIE cabinet (SALW-PNL-6002K).

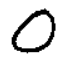
vac

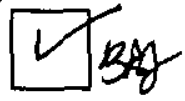

5.3.30 Close breaker \#14. Measure voltage at the terminal board in the FGM junction box on the outside of the WFIE cabinet (SALW-PNL-6002K).

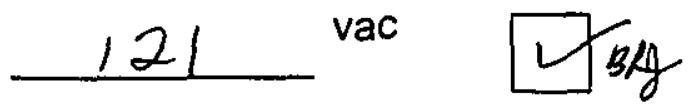

5.3.31 Open breaker \#14. Measure zero voltage at the terminal board in the FGM junction box on the outside of the WFIE cabinet (SALW-PNL-6002K). vac sRg

5.3.32 Close breaker \#3. Measure voltage at the terminal board TB10 in the instrument . . cabinet (SALW-PNL-6005K). $\_21 \_$vac

5.3.33 Open breaker \#3. Measure zero voltage at the terminal board TB10 in the instrument cabinet (SALW-PNL-6005K). vac

5.3.34 Close breaker \#5. Measure voltage at the terminal board TB13 in the instrument cabinet (SALW-PNL-6005K).

5.3.35 Open breaker \#5. Measure zero voltage at the terminal board TB13 in the instrument cabinet (SALW-PNL-6005K). vac

5.3.36 Close breaker \#12. Measure voltage at the terminal board in the instrument cabinet (SALW-PNL-6005K). 121 vac

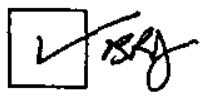

5.3.37 Open breaker \#12. Measure zero voltage at the terminal board in the instrument cabinet (SALW-PNL-6005K). O. vac

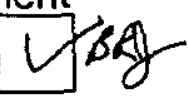

5.3.38 Close breaker \#4. Measure voltage at the receptacle in the instrument air cabinet (SALW-PNL-6001K). vac

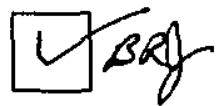

5.3.39 Open breaker \#4. Measure zero voltage at the receptacle in the instrument air cabinet (SALW-PNL-6001K).
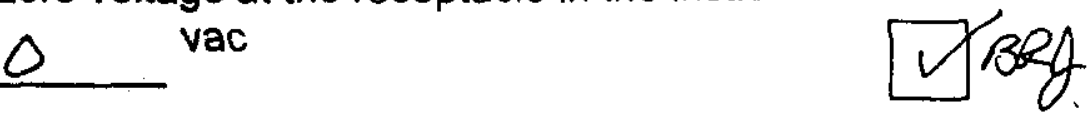

5.3.40 Close breaker \#6. Measure voltage at the terminal board in the intrinsic safe panet (SALW-PNL-6006K). vac

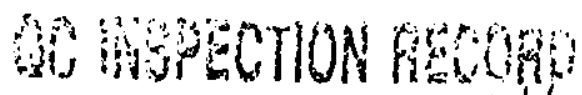

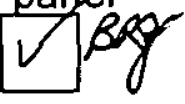
OF 
HNF-4277

REVISION 0

5.3.41 Open breaker \#6. Measure zero voltage at the terminal board in the intrinsic safe panel (SALW-PNL-6006K).

$$
\mathrm{O} \text { vac }
$$

Jog.

5.3.42 Close breaker \#7. Measure voltage at the receptacle in the WFIE cabinet (SALWPNL-6002K). vac

5.3.43 Open breaker \#7. Measure zero voltage at the receptacle in the WFIE cabinet (SALW-PNL-6002K).

0 vac

Y rat

5.3.44 Close breaker \#8. Measure voltage at the receptacle in the water cabinet (SALWPNL-6003K).

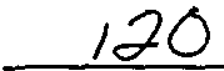
vac

Y sty

5.3.45 Open breaker \#8. Measure zero voltage at the receptacle in the water cabinet (SALW-PNL-6003K). vac

Exception 10 Check 24 vd c supply outputs (see below)

5.3.46 Open the 100 ampere main breaker in the panel board (SALW-DP-6001K).

$\square$ SAg

$\square$ soft

5.3.47 Open the transformer disconnect switch (SALW-DS-6003K).

5.3.48 Open the main disconnect switch (SALW-DS-6002K).

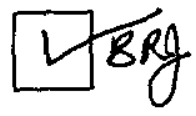

Voltage checks completed satisfactorily.

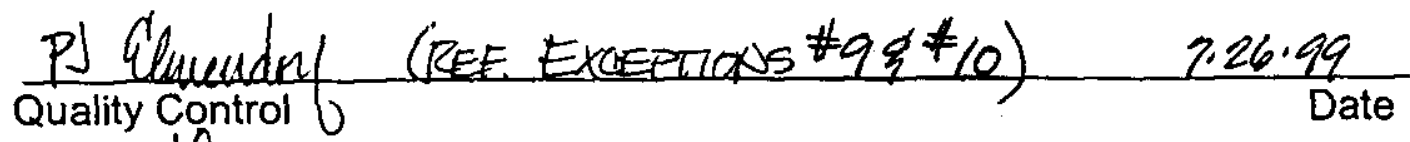

Exception z 10 dc check.

Verify steps $5.3 .1 \rightarrow 05.3 .5 \sim 3 e g$.

Do stops 5.3 .17 and $5.3 .18 \vee B$ Ry

Do step 5.3 .34 r B elf

Install Fuses FD WFC CBAP BRit

Check for $120 \mathrm{vac}+10 \mathrm{vac}$ at 24 volt power supplies 120.2

Check for l20vac clover at 24 volt power supplies. 120.2 Open fuses FD and FCV 2 be f 24 volt power supplies. $24.19 \mathrm{BAf}$

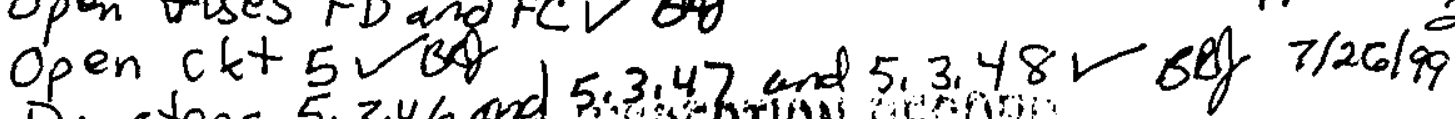

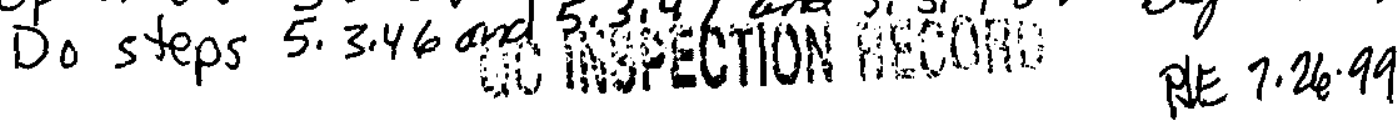

WORK ORDER 2 H9903385F PAGE A12

PAGE 145 OF 


\subsection{CALIBRATIONS}

Instrumentation equipment on the skid requires calibration prior to the functional testing. Lockheed Martin procedures will be used for this calibration. The table below identifies the equipment requiring calibration and the procedure for performing the calibration.

\begin{tabular}{l|ll}
\hline \multicolumn{1}{c|}{ INSTRUMENT } & \multicolumn{1}{c}{ LOCATION } & \multicolumn{1}{c}{ PROCEDURE } \\
\hline SALW-PS-6004K & INSTRU. AIR CAB. & $6-P C D-508$ \\
SALW-WFT-6002K & WFIE CABINET & $6-P C D-361$ \\
SALW-LT-6003K & WATER CABINET & $6-P C D-361$ \\
SALW-SGT-6001K & WFIE CABINET & $6-P C D-361$ \\
SALW-CONV-6001K & WFIE CABINET & $6-T F-365$ \\
SALW-FQIT-6001K & INSTRUMENT CAB. & Data sheet \& Vendor Man.* \\
SALW-PI-6006K & AIR COMPRS. CABINET & $6-T F-509$ \\
SALW-PI-6001K & WFIE CABINET & $6-T F-509$ \\
SALW-PI-6005K & WFIE CABINET & $6-T F-509$ \\
SALW-PI-6002K & WFIE CABINET & $6-T F-509$ \\
SALW-PI-6003K & WFIE CABINET & $6-T F-509$ \\
SALW-PI-6004K & WFIE CABINET & $6-T F-509$ \\
SALW-PI-6007K & AIR COMPRS. CABINET & $6-T F-509$ \\
SALW-FI-6001K & WATER CABINET & VENDOR MANUAL * \\
SALW-PI-6008K & WATER CABINET & $6-T F-509$ \\
\hline
\end{tabular}

Calibrations completed. * will be done under PartII. BRg 8/10/99

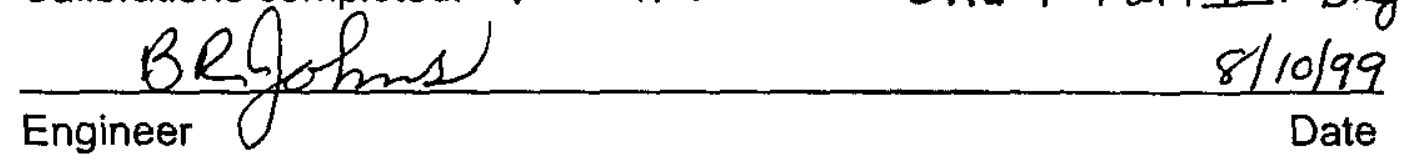

\subsection{PLC PROGRAMMING}

This section is where the program for the PLC will be entered into the SLC 500 and the DTAM programmed. Power will be required at the instrument cabinet to power up the PLC and the receptacle (provides power for the laptop computer). Lockheed Martin Interim Stabilization engineering will perform the programming of the PLC. The final software programs shall be documented as required by HNF-3828, section 3.4. This documentation is not part of this ATP, but will be tracked by the Acceptance for Beneficial Use (ABU) document.

PLC programmed.

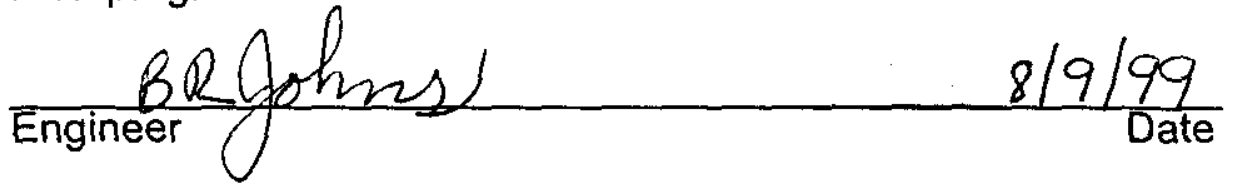




\subsection{PUMPING AND INSTRUMENTATION CONTROL SKID ELECTRICAL AND PROCESS AIR POWER-UP}

5.6.1 ENSURE the skid and remote equipment are connected before proceeding with the functional testing.

5.6.2 ENERGIZE the Pumping and Instrumentation Control Skid by CLOSING the following DISCONNECT SWITCHES in the order found below:

\begin{tabular}{|l|c|}
\hline DISCONNECT SWITCH & $\begin{array}{c}\text { ENERGIZED } \\
(\checkmark)\end{array}$ \\
\hline SALW-DS-6002K & $\vee \checkmark \checkmark$ \\
\hline SALW-DS-6003K & $\checkmark \checkmark$ \\
\hline SALW-DS-6004K & $\checkmark \checkmark \checkmark$ \\
\hline SALW-DS-6005K & $\checkmark \checkmark \checkmark$ \\
\hline
\end{tabular}


NOTE - The following circuit breakers are located in SALW-DP-6001K "SALW SKID DIST PNL".

5.6.3 ENERGIZE the Pumping and Instrumentation Control Skid by CLOSING the following Circuit Breakers in the order found below:

\begin{tabular}{|l|l|}
\hline \multicolumn{1}{|c|}{ DISCONNECT SWITCH } & ENERGIZED \\
\hline "MAIN" & \\
\hline 7, (WEIGHT FACTOR INSTRUMENT & \\
\hline 3, (LEAK DETECTION/HEAT TRACE) & \\
\hline 8, (WATER TANK CABINET HEATER) & \\
\hline 5, (INSTRUMENT ENCLOSURE [PLC]) & \\
\hline 4, (AIR COMPRESSOR CABINET HEATER \& \\
RECEPTACLE)
\end{tabular}


5.6.4 ACKNOWLEDGE any initial skid or FGM alarms.

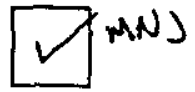

5.6.5 OPEN valve SALW-V-6034K (located in the Air COMP Cabinet).

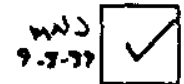

5.6.6 START air compressor SALW-CMP-6001K "SALW SKID IA COMP" by+-s? POSITIONING switch on the SALW-DS-6004K to the ON position.

nold

5.6.7 VERIFY that Air Compressor starts and builds up pressure AND shuts off at 86 to 94 psig, as indicated by pressure gauge SALW-PI-6006K (AIR DRYER INLET PRESS).

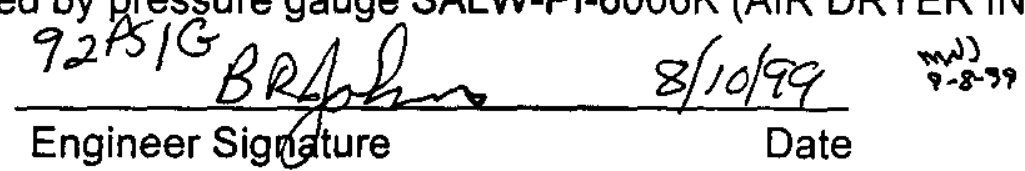

5.6.8 CHECK the tubing in the instrument air cabinet using a soap and water test to visually identify any air leaks. Repair as necessary. Deenergize the compressor motor and bleed off air as necessary to make repairs.

5.6.9 BLEED off air by slowly opening valve SALW-V-604 $K \mathrm{~K}$ until the compressor restarts, then close valve.

$$
\text { Ex }{ }^{\text {Bnop }} \text { Eception } \# 11
$$

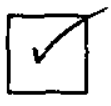

5.6.10 VERIFY the air compressor restarts upon low pressure of 58 to $62 \mathrm{psig}$.

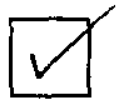

5.6.11 VALVE in air to the Pumping and Instrumentation Control Skid Water Tank by SLOWLY PERFORMING the following (Refer to H-14-103535 Sheet 1):

5.6.10 CHECK for air leaks as each remaining step in this section is performed. Make repairs as necessary. Deenergize compressor motor and bleed off air pressure if necessary to make the repairs.

5.6.11 SLOWLY OPEN valve SALW-V-6025K (located in the air compressor cabinet).

5.6.12 SLOWLY OPEN valve SALW-V-6027K (located near the water tank).

5.6.13 SLOWLY OPEN valve SALW-V-6028K (located near the water tank).

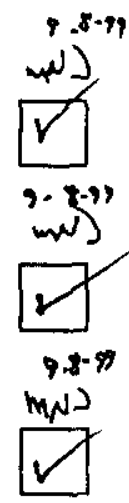

Whacton Groto 
5.6.14 ADJUST Pressure Regulator Valve SALW-PCV-6006K to $30 \mathrm{psi}$ ( $\pm 3 \mathrm{psig}$ ) as indicated by pressure gauge SALW-PI-6008K (WTR TK PRESS).

5.6.15 VALVE IN air to SALW-PNL-6002K (WFIE Cabinet) by PERFORMING the following (Refer to $\mathrm{H}-14-103535$ Sheet 1 ):

5.6.16 SLOWLY OPEN valve SALW-V-6026K (located in the Air Compressor Cabinet).

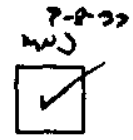

5.6.17 SLOWLY OPEN valve SALW-V-6001K, located in the bottom of SALW-PNL-6002K (WFIE Cabinet).

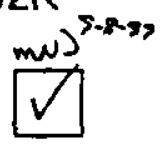

5.6.18 ADJUST pressure control valve SALW-PCV-6001K in SALW-PNL-6002K (WFIE Cabinet) to $20 \mathrm{psi}$ ( $\pm 2.5 \mathrm{psi}$ ) as indicated by the pressure gauge located on the face of the valve.

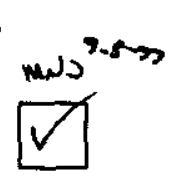

5.6.19 SLOWLY OPEN valve SALW-V-6004K, located in the middle of SALW-PNL-6002K, (WFIE Cabinet).

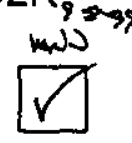

5.6.20 SLOWLY OPEN valve SALW-V-6003K, located in the middle of SALW-PNL-6002K (WFIE Cabinet).

CAUTION: The next three steps cause air to flow from ports on outside of WFIE cabinet.

5.6.21 SLOWLY OPEN valve SALW-V-6005K, located in the bottom left of SALW-PNL-6002K (WFIE Cabinet).

m.

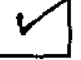

5.6.22 SLOWLY OPEN valve SALW-V-6006K, located in the bottom left of SALW-PNL-6002K (WFIE Cabinet).

5.6.23 SLOWLY OPEN valve SALW-V-6007K, located in the bottom left of SALW-PNL-6002K (WFIE Cabinet).

5.6.24 SLOWLY OPEN valve SALW-V-6020K, located in the middle left of SALW-PNL-6002K (WFIE Cabinet).
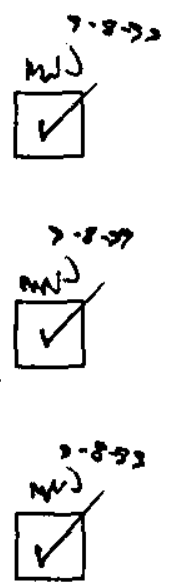
5.6.25 SLOWLY OPEN valve SALW-V-6021K, located in the middle left of SALW-PNL-6002K (WFIE Cabinet).

5.6.26 SLOWLY OPEN valve SALW-V-6019K, located in the middle left of SALW-PNL-6002K (WFIE Cabinet).

5.6.27 ADJUST the air flow through the diptubes by PERFORMING the following:

5.6.28 ADJUST flow to dip tubes to $1.5 \mathrm{CFH}( \pm 0.5 \mathrm{CFH})$ as indicated by SALW-FIV-6̈002K.

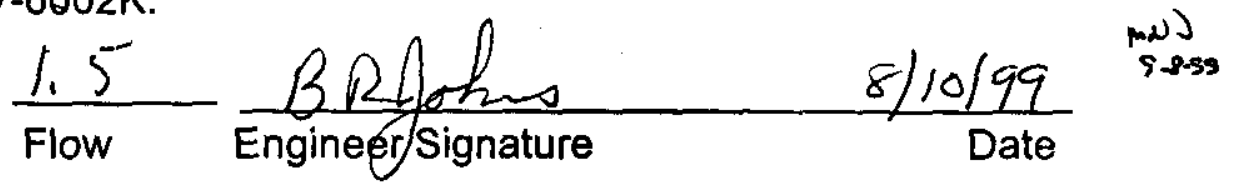

5.6.30 ADJUST flow to dip tubes to $1.5 \mathrm{CFH}( \pm 0.5 \mathrm{CFH})$ as indicated by SALW-FIV-6003K.

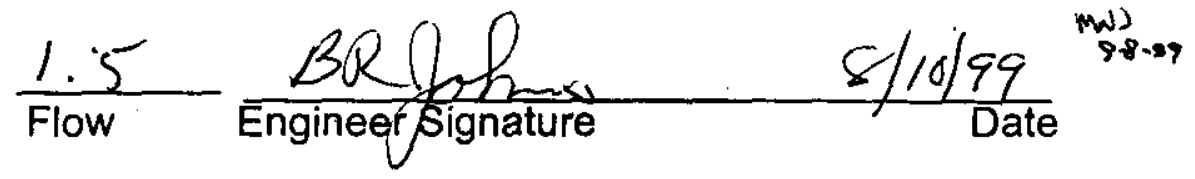

5.6.31 ADJUST flow to dip tubes to $1.5 \mathrm{CFH}( \pm 0.5 \mathrm{CFH})$ as indicated by SALW-FIV-6004K.

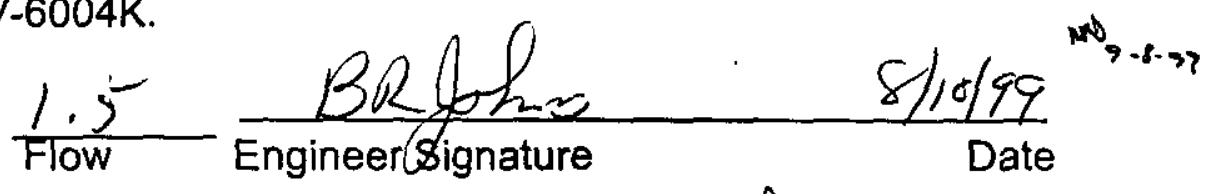

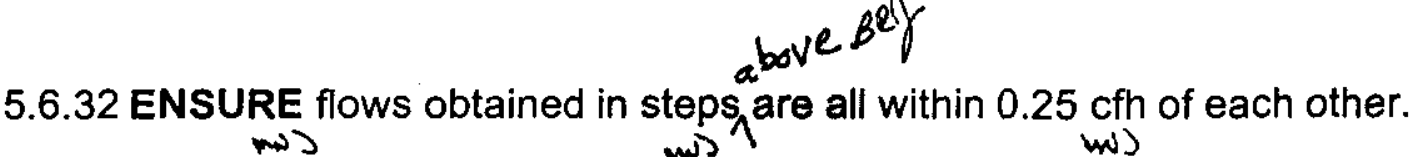
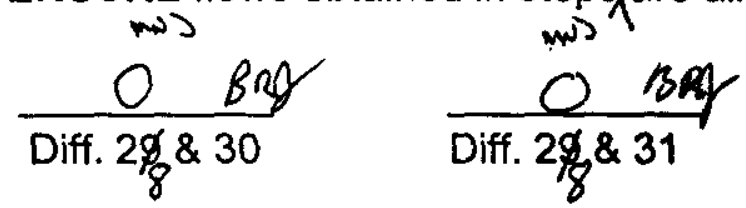

(1) 642

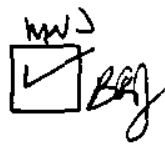

5.6.33 VALVE IN SALW-WFT-6002K AND SALW-SGT-6001K by PERFORMING the following:

5.6.34 ENSURE the LOW side AND HIGH side isolation valves, located on SALW-V-6036K $8 \rightarrow \rightarrow$ in cabinet SALW-PNL-6002K (WFIE Cabinet) are OPEN.

5.6.35 ENSURE SALW-WFT-6002K EQUALIZING valve on valve manifold SALW-V-6036K in cabinet SALW-PNL-6002K (WFIE Cabinet) is CLOSED.

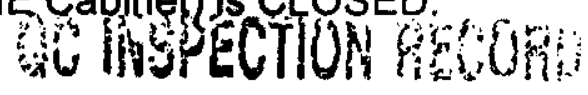

5.6.36 ENSURE the LOW side AND the HIGH side isolation valves, located on SALW-V-6035K in cabinet SALW-PNL-6002K (WFIE Cabinet) are OPEN. 
5.6.37 ENSURE SALW-SGT-6001K equalizing valve on valve manifold SALW-V-6035K in cabinet SALW-PNL-6002K (WFIE Cabinet) is CLOSED.

5.6.38 CONFIRM that a signal is present between SALW-PNL-6002K (WFIE Cabinet) Instruments and the Programmable Logic Controller by PERFORMING the following:

5.6.39 VERIFY Weight Factor is approximately $0.0^{\prime \prime}\left( \pm 0.5^{\prime \prime}\right)$ Water Gauge as indicated by

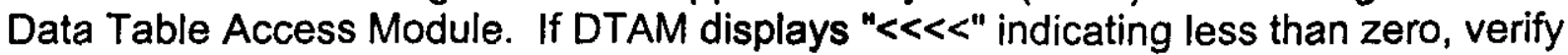
continuity between the transmitter and the Programmable Logic Controller and proceed with the test.

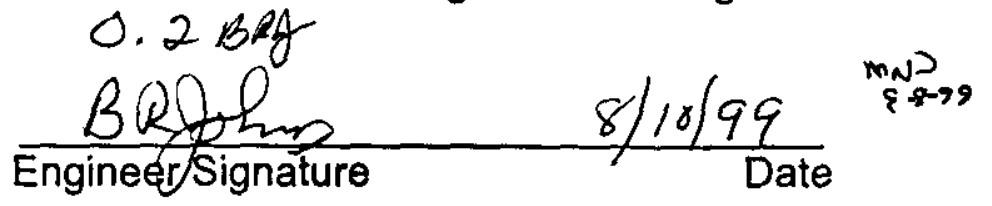

5.6.40 VERIFY Specific Gravity is approximately $0.0^{\prime \prime}\left( \pm 0.5^{\prime \prime}\right)$ Water Gauge as indicated by

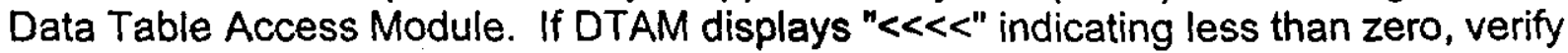
continuity between the transmitter and the Programmable Logic Controller and proceed with the test.

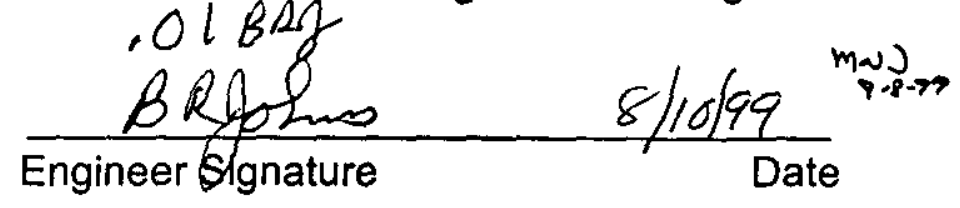

5.6.41 OPEN valve SALW-V-6035K. (Equalizeng) BRf

5.6.42 CLOSE valves SALW-V-6035K HI and LO.
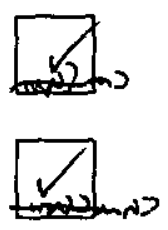

5.6.43 OPEN valve SALW-V-6036K. (Equalizing) BRy

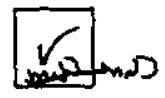

5.6.44 CLOSE valves SALW-V-6036K HI and LO.

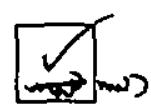

5.6.45 CLOSE valves SALW-V-6019K, SALW-V-6021K and SALW-V-6020K.

5.6.46 VERIFY all air leaks repaired.
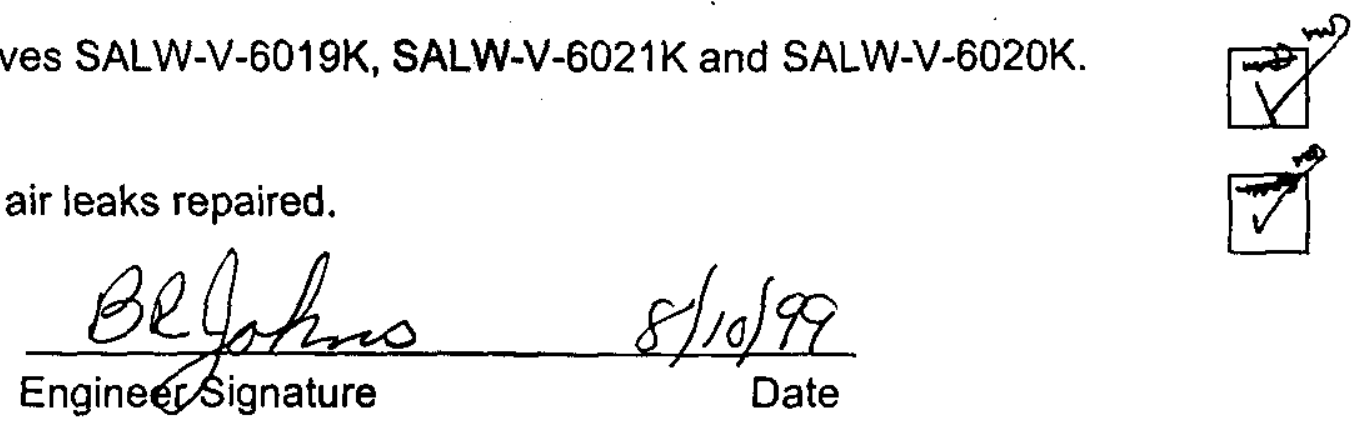

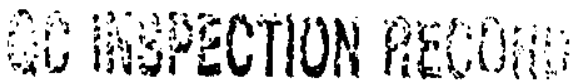


5.6.47 Engineer VERIFY that section 5.6 is complete by SIGNING below.

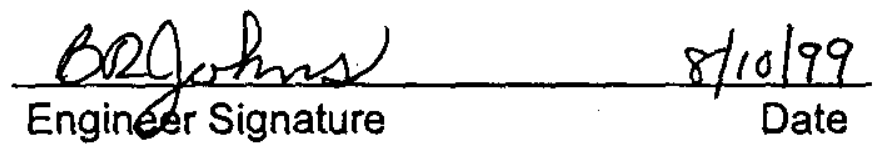

5.6.48 Quality Control Inspector VERIFY that section 5.6 is complete by signing below.

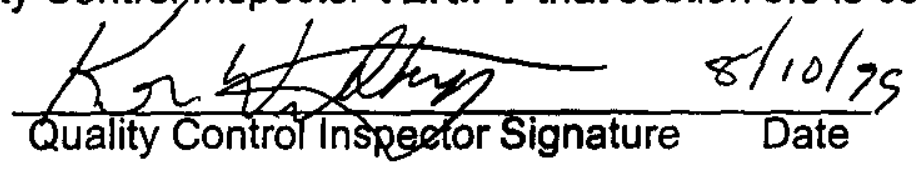




\subsection{PUMPING AND INSTRUMENTATION CONTROL SKID WATER DRIP SYSTEM}

5.7.1 ATTACH temporary portable hose from diptube outlet to high and medium diptubes from the bottom of the weight factor enclosure, (from valves SALW-V-6005K and SALW-V-6007K). If need. Bucket used to catch water. Bry s/10/99

- $\quad$ ROUTE the flexible hose to a suitable drain AND SECURE.

5.7.2 ACTUATE the Dip Tube Drip system by SLOWLY OPENING the following valves:

\begin{tabular}{|l|c|}
\hline \multicolumn{1}{|c|}{ VALVES } & $\begin{array}{c}\text { OPEN } \\
(\checkmark)\end{array}$ \\
\hline $\begin{array}{l}\text { SALW-V-6018K } \\
\text { located in the bottom right of SALW-PNL-6002K (WFIE Cabinet) }\end{array}$ & \\
\hline $\begin{array}{l}\text { SALW-V-6016K } \\
\text { located in the middle of SALW-PNL-6002K (WFIE Cabinet) }\end{array}$ & \\
\hline $\begin{array}{l}\text { SALW-V-6013K } \\
\text { located in the middle of SALW-PNL-6002K (WFIE Cabinet) }\end{array}$ & \\
\hline $\begin{array}{l}\text { SALW-V-6008K } \\
\text { located in the middle of SALW-PNL-6002K (WFIE Cabinet) }\end{array}$ & \\
\hline
\end{tabular}

\section{CAUTION}

Relief valve (SALW-PRV-6001K) will actuate and relieve pressure at 25 psig.

5.7.3 CAREFULLY ADJUST Pressure Regulator SALW-PCV-6005K, located in the bottom of SALW-PNL-6002K (WFIE Cabinet) to $20 \mathrm{psig}$ ( $\pm 2 \mathrm{psig}$ ) as indicated by SALW-PI-6001K in the middle of SALW-PNL-6002K (WFIE Cabinet).

5.7.4 ADJUST valve SALW-V-6014K to allow APPROXIMATELY 2 drops/second as indicated by sight glass SALW-FG-6001K ( 1 drop/second).

5.7.5 ADJUST valve SALW-V-6015K to allow APPROXIMATELY 2 drops/second as indicated by sight glass SALW-FG-6002K ( \pm 1 drop/second).

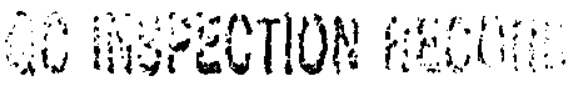




\section{HNF-4277 \\ REVISION 0}

5.7.6 VALVE OUT the dip tube drip water by SLOWLY CLOSING the following:

\begin{tabular}{|l|c|}
\hline \multicolumn{1}{|c|}{ VALVE } & $\begin{array}{c}\text { CLOSED } \\
(\end{array}$ \\
\hline $\begin{array}{l}\text { SALW-V-6015K } \\
\text { located in the middle of SALW-PNL-6002K (WFIE Cabinet) }\end{array}$ & \\
\hline $\begin{array}{l}\text { SALW-V-6014K } \\
\text { located in the middle of SALW-PNL-6002K (WFIE Cabinet) }\end{array}$ & $\checkmark$ \\
\hline $\begin{array}{l}\text { SALW-V-6008K } \\
\text { located in the middle of SALW-PNL-6002K (WFIE Cabinet) }\end{array}$ & $\checkmark$ \\
\hline $\begin{array}{l}\text { SALW-V-6013K } \\
\text { located in the middle of SALW-PNL-6002K (WFIE Cabinet) }\end{array}$ & \\
\hline
\end{tabular}

$$
\text { Ensure BRY }
$$

5.7.7 OPEN equalizing valve SALW-V-6035.

5.7.8 CLOSE HI and LO isolation valves on SALW-V-6035. Ensave Bef

5.7.9 OPEN equalizing valve SALW-V-6036. Ensere bely

5.7.10 CLOSE HI and LO isolation valves on SALW-V-6036. Ensure BAy

5.7.11 CLOSE the following valves in the order listed: SALW-V-6019, SALW-V-6021, SALW-V-6020, SALW-V-6007, SALW-V-6006, and SALW-V-6005.

5.7.12 SLOWLY open valve SALW-V-6044K in the SALW-PNL-6002K (Air Compressor Cabinet)

5.7.13 ADJUST pressure regulator SALW-PCV-6007K outside SALW-PNL-6002K (Air Compressor Cabinet) to $75+/-10$ psig.

5.7.14 CLOSE valve SALW-V-6044K in the SALW-PNL-6002K (Air Compressor Cabinet).

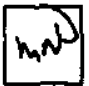

5.7.15 SLOWLY open valve SALW-V-6048K in the SALW-PNL-6002K (Air Compressor Cabinet).

5.7.16 ADJUST pressure regulator SALW-PCV-6008K outside SALW-PNL-6002K (Air f (Compressor Cabinet) to $75+/-10$ psig. racepl

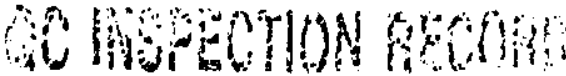
$\min$ 12 
5.7.17 CLOSE valve SALW-V-6048K in the SALW-PNL-6002K (Air Compressor Cabinet).

5.7.18 SLOWLY crack open valve SALW-V-6046K in the SALW-PNL-6002K (Air Compressor Cabinet) to VERIFY air flow at the fitting for the AOV. Then close value SALW-U-6046k. Bg g

5.7.19 SLOWLY crack open valve SALW-V-6047K (with SALW-V-6046K still cracked open) in the SALW-PNL-6002K (Air Compressor Cabinet) to VERIFY air flow at the drain line 127

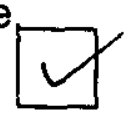

5.7.20 CLOSE valve SALW-V-6047K in the SALW-PNL-6002K (Air Compressor Cabinet).

5.7.21 SLOWLY crack open valve SALW-V-6043K in the SALW-PNL-6002K (Air Compressor Cabinet) to VERIFY air flow at the tank drain line.
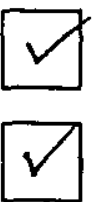

5.7.22 CLOSE valve SALW-V-6043K in the SALW-PNL-6002K (Air Compressor Cabinet).

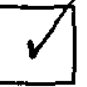

5.7.23 Engineer VERIFY that section 5.7 is complete by SIGNING below.

* Exception 12 for steps 5.7 .13 to $5.7,17$. To be performed $\frac{\text { BRothos }}{\text { Engineer Signature }} 8 / 10199$

5.7.24 Quality Control Inspector VERIFY that section 5.7 is complete by signing below.
$\forall$
Kar

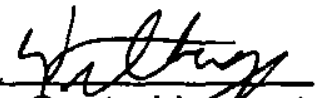
$8 / 16 / 79$
Quality Controltrispector Signature Date 


\subsection{VERIFY DATA TABLE ACCESS MODULE AND OPERATOR CONTROL STATION ANALOG INPUT SIGNALS}

\section{Water Tank Level Transmitter}

5.8.1 PREPARE the Water Tank Level Transmitter SALW-LT-6003K for test signals by PERFORMING the following:

5.8.2 ENSURE valve SALW-V-6029K, located in the bottom of SALW-PNL-6003K (WATER TANK ENCL), is CLOSED.

5.8.3 ENSURE valve SALW-V-6031K, located in the bottom of SALW-PNL-6003K (WATER TANK ENCL), is CLOSED.

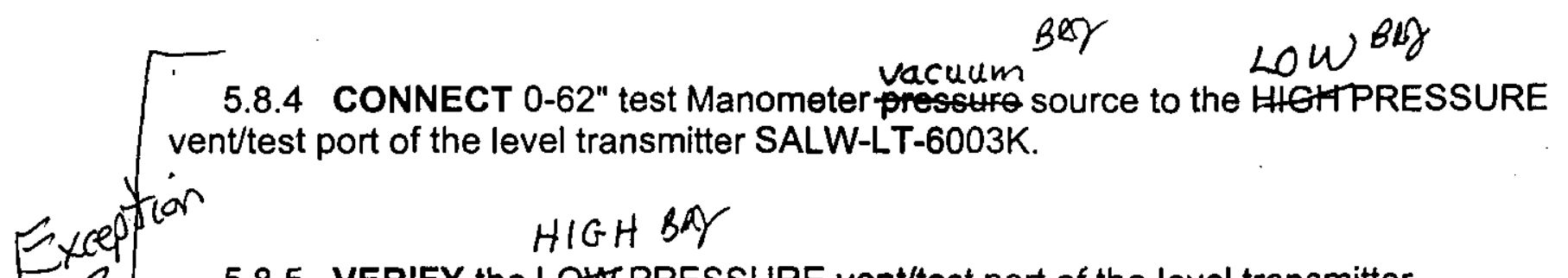

5.8.5 VERIFY the LOW PRESSURE vent/test port of the level transmitter SALW-LT-6003K is OPEN to atmosphere.

5.8.6 ADJUST the test Manometer on the SALW-LT-6003K to a vacuum Gauge ( $\pm 1 ")$.

5.8.7 RECORD the following:(screen 20 on DTAM)

\section{DATA TABLE ACCESS MODULE WATER TANK LEVEL (RANGE: 28.5 TO 33.5 Inches)}

\section{1}

NOTE - In the next step, the alarm should annunciate between 11.75" and 12.75" Water Gauge.

5.8.8 VERY SLOWLY DECREASE the Level Transmitter test Manometer pressure UNTIL the Data Table Access Module "PIC WATER LOW" alarm (alarm 9, screen 109) annunciates. 
5.8.9 ACKNOWLEDGE the Water Tank Low Level alarm at the Data Table Access Module.

5.8.10 OBSERVE the Data Table Access Module AND RECORD the water tank level readings below(screen 20 on DTAM)

\begin{tabular}{c} 
DATA TABLE ACCESS MODULE \\
WATER TANK LEVEL \\
(RANGE 11.75 to 12.75 inches Water Gauge) \\
12.2 \\
\hline
\end{tabular}

5.8.11 SLOWLY INCREASE the Level Transmitter test Manometer pressure to $15.5^{\text {" Water }}$ Gauge.

5.8.12 OBSERVE the Data Table Access Module AND RECORD the water tank level readings below:(screen 20 on DTAM)

\section{DATA TABLE ACCESS MODULE WATER TANK LEVEL (RANGE 14.5 to 16.5 inches)}

15.5

Excestion 13

BO) port, AND RE-INSTALL vent plugs. 
5.8.18 OPEN valve SALW-V-6031K, located in the bottom of SALW-PNL-6003K (WATER TANK ENCL).

\section{WEIGHT FACTOR TEST}

5.8.19 VERIFY that NO Programmable Logic Controller input signals are FORCED and that the forcing function is DISABLED.

5.8.20 CONNECT the 0-500" Water Gauge test Manometer pressure source to the HIGH PRESSURE dip tube on the side of the "WFIE Cabinet."

5.8.21 ENSURE SALW-V-6001K is CLOSED.

5.8.22 ENSURE SALW-V-6005K is OPEN.

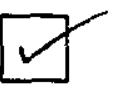

5.8.23 ENSURE SALW-V-6006K is OPEN.
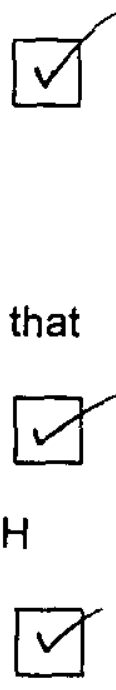
5.8.28 OBSERVE Data Table Access Module(screen 24) AND RECORD the Weight Factor on the table below.
DATA TABLE ACCESS MODULE
WEIGHT FACTOR READING
(RANGE 120 to 130 inches)

\section{3}

5.8.29 BLEED off pressure from the manometer.

5.8.30 DISCONNECT the 0-500" test Manometer pressure source.

\subsubsection{CLOSE SALW-V-6006K.}

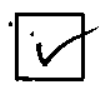

5.8.32 OPEN SALW-WFT-6002K equalizing valve, located on SALW-V-6036K 3-Valve Manifold in cabinet SALW-PNL-6002K (WFIE Cabinet).

5.8.33 CLOSE the LOW side and HIGH side isolation valves, located on SALW-V-6036K 3-Valve Manifold in cabinet SALW-PNL-6002K (WFIE Cabinet).

\section{SPECIFIC GRAVITY TEST}

NOTE - A mock signal to the specific gravity transmitter is required to keep a low saltwell level alarm from preventing testing of other instrumentation.

5.8.34 CONNECT the 0-50" Water Gauge test Manometer pressure source to the HIGH PRESSURE dip tube.

5.8.35 ENSURE SALW-V-6007K is OPEN.

5.8.36 ENSURE SALW-V-6005K is OPEN.

5.8.37 ENSURE the LOW side and the HIGH side isolation valves, located on SALW-V-6035K in cabinet SALW-PNL-6002K (WFIE Cabinet) are OPEN.

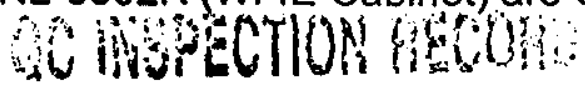


5.8.38 CLOSE the Specific Gravity Transmitter equalizing valve located on SALW-V-6035K in cabinet SALW-PNL-6002K (WFIE Cabinet).

5.8.39 SET the test Manometer to 5" Water Gauge ( $\pm .3 ")$.

5.8.40 OBSERVE Data Table Access Module(screen 24) AND RECORD the Specific Gravity reading on the table below.

\section{DATA TABLE ACCESS MODULE SPECIFIC GRAVITY READING \\ (RANGE 4.65 to 5.35 inches)}

\section{9} Exception Remoue manometer from High Pressure DIP tube, Bleed

$14 \mathrm{gry}$

Open Equalizing value SALW-V-6035K
Close Low and High side valves on 5

BU FLOW METER TEST C/OSe Low and High side Valves on
SALW-FQIT-6001K (SUPERNATANT FLOW XMIT), located in cabinet SALW-PNL-

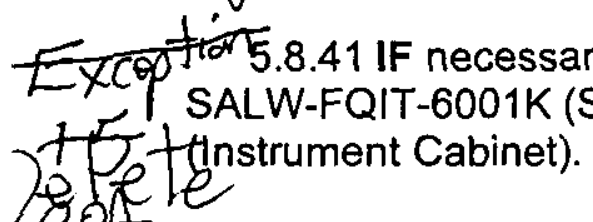

SALWUV -

$6035 k$.

(SUPERNATANT FLOW XMIT), located in cabinet SALW-PNL-6005K

Bथि

BRY 5.8.42 ENSURE SALW-FQIT-6001K is powered and configured for simulated flow signals.

5.8.43 SIMULATE a flow signal of $2.0 \mathrm{gpm}$ ( $50 \%$ span) with the hand held calibrator, or from flowmeter face plate.

5.8.44 VERIFY the SALW-FQIT-6001K transmitter is operating properly by RECORDING the following:(screen 24 on DTAM)

\begin{tabular}{|c|c|}
\hline $\begin{array}{c}\text { DATA TABLE ACCESS MODULE } \\
\text { SUPERATANT FLOW } \\
\text { (RANGE: } 1.8 \text { TO 2.2 GPM) }\end{array}$ & $\begin{array}{c}\text { SUPERNATANT FLOW } \\
\text { XMIT } \\
\text { SUPERNATANT FLOW } \\
\text { (RANGE: } 1.8 \text { TO 2.2 GPM) }\end{array}$ \\
\hline 2.00 & 2.000 \\
\hline
\end{tabular}




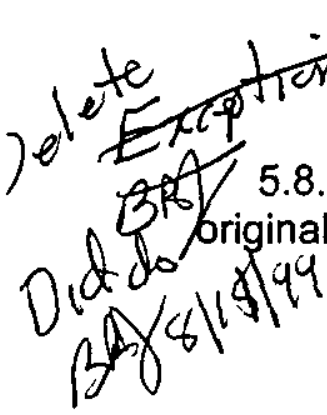

5.8.45 RESTORE the SALW-FQIT-6001K (SUPERNATANT FLOW TRANSMITTER) to its

\section{SUCTION AND DISCHARGE PRESSURE SIGNAL}

5.8.46 CONNECT a current source to PSPT+ and PSPT- at the intrinsic side terminal board in the Intrinsic Safe panel.

5.8.47 SET the current to $4 \mathrm{~mA}$ and record the suction pressure on SALW-PI-6012K in the table below. Reading is to be approximately zero.

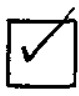

5.8.48 SET the current source to 2 Am and fincord the suction pressure in the table below. Reading is to be greater than zero.

5.8.49 DISCONNECT the current source.

5.8.50 CONNECT a current source to PGPT + and PDPT- at the intrinsic side terminal board in the Intrinsic Safe panel.

5.8.51 SET the current to $4 \mathrm{~mA}$ and record the discharge pressures on SALW-PI-6011K and on the DTAM in the table below. Readings are to be approximately zero.

5.8.52 SET the current source to $20 \mathrm{~mA}$ and record the discharge pressures in the table below. Readings are to be greater than zero.

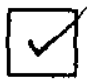

5.8.53 DISCONNECT the current source.

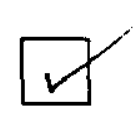


5.8.54 RECORD the following pressures on the table below:(screen 26 on DTAM)

\begin{tabular}{|c|c|c|c|c|}
\hline $\begin{array}{c}\text { SALW-PI-6012K } \\
\text { JET PUMP } \\
\text { SUCTION } \\
\text { PRESSURE }\end{array}$ & $\begin{array}{c}\text { DTAM } \\
\text { DISCHARGE } \\
\text { PRESSURE }\end{array}$ & $\begin{array}{c}\text { SALW-PI-6011K } \\
\text { JET PUMP } \\
\text { DISCHARGE } \\
\text { PRESSURE }\end{array}$ & \\
\hline 0.1 & At $4 \mathrm{~mA}$ & 0 & 0.4 & At $4 \mathrm{~mA}$ \\
\hline 100.1 & At $20 \mathrm{~mA}$ & 300 & 300.2 & At $20 \mathrm{~mA}$ \\
\hline
\end{tabular}

\section{PIT FLAMMABLE GAS MONITOR ANALOG SIGNAL TO PLC}

5.8.55 CONNECT a current source to terminal board TB1 in the PICS Instrument Enclosure, points FGM $0(+)$ and FGM $0(-)$.

5.8.56 SET current source to $4 \mathrm{~mA}( \pm .25 \mathrm{~mA})$.

5.8.57 RECORD the Data Table Access Module Flammable Gas DISPLAY on the "Pit FGM Input/Output Table" below.

5.8.58 SET current source to $10 \mathrm{~mA}( \pm .25 \mathrm{~mA})$.

5.8.59 RECORD the Data Table Access Module Flammable Gas display on the "Pit FGM Input/Output Table" below.

5.8.60 SET current source to $20 \mathrm{~mA}( \pm .25 \mathrm{~mA})$.

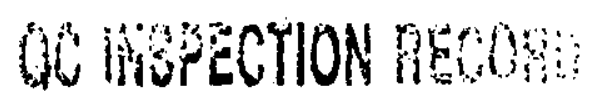


5.8.61 RECORD the Data Table Access Module Flammable Gas display on the "Pit FGM Input/Output Table" below.(screen 28 on DTAM)

\begin{tabular}{|c|c|}
\hline \multicolumn{2}{|c|}{ Pit FGM Input/Output Table } \\
\hline $\begin{array}{c}\text { Input } \\
(\mathbf{m A})\end{array}$ & $\begin{array}{c}\text { Output (as displayed on } \\
\text { Data Table Access Module) }\end{array}$ \\
\hline 4 & 0 \\
\hline 10 & 11.3 \\
\hline 20 & 30.0 \\
\hline
\end{tabular}

5.8.62 DISCONNECT the current source.

\section{DOME SPACE FLAMMABLE GAS MONITOR ANALOG SIGNAL TO PLC}

5.8.63 CONNECT a current source to terminal board TB1 in the PICS Instrument Enclosure, points FGM 1(+) and FGM 1(-).

5.8.64 SET current source to $4 \mathrm{~mA}( \pm .25 \mathrm{~mA})$.

5.8.64 RECORD the Data Table Access Module Flammable Gas DISPLAY on the "Dome Space FGM Input/Output Table" below.

5.8.65 SET current source to $10 \mathrm{~mA}( \pm .25 \mathrm{~mA})$.

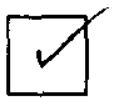

5.8.66 RECORD the Data Table Access Module Flammable Gas display on the "Dome Space FGM Input/Output Table" below.

5.8.67 SET current source to $20 \mathrm{~mA}( \pm .25 \mathrm{~mA})$.

5.8.68 RECORD the Data Table Access Module Flammable Gas display on the "Dome

Space FGM Input/Output Table" below.(screen 28 on DTAM)
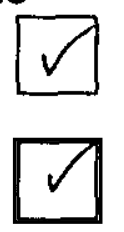

Ghoreton then 


\begin{tabular}{|c|c|}
\hline \multicolumn{2}{|c|}{ Dome Space FGM Input/Output Table } \\
\hline $\begin{array}{c}\text { Input } \\
\text { (mA) }\end{array}$ & $\begin{array}{c}\text { Output (as displayed on } \\
\text { Data Table Access Module) }\end{array}$ \\
\hline 4 & .0 \\
\hline 10 & 11.3 \\
\hline 20 & 30.0 \\
\hline
\end{tabular}

5.8.69 DISCONNECT the current source.

\section{THERMOCOUPLE INPUTS TO PLC}

5.8.70 WARM thermocouple SALW-TE-6004K, located in the Instrument Enclosure.

5.8.71 VERIFY Data Table Access Module(screen 25)displays a changed temperature.

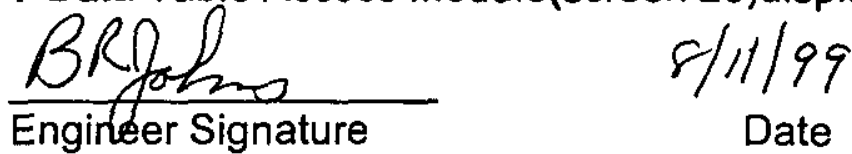

5.8.72 ALLOW SALW-TE-6004K to return to ambient temperature.

$$
1 \text { Bef } 811199
$$

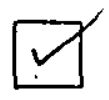

5.8.73 WARM thermocouple SALW-TE-600 $\mathrm{K}$, located in SALW-PNL-6001K INSTRUMENT AIR ENCLOSURE.

5.8.74 VERIFY Data Table Access Module(screen 25) displays a changed temperature.

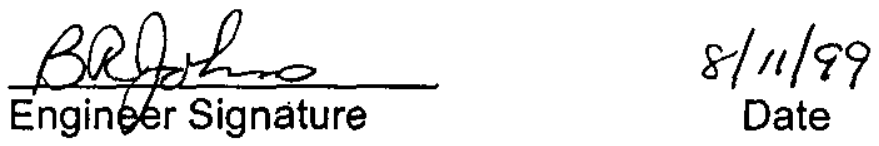

5.8.75 ALLOW SALW-TE-6003K to return to ambient temperature.

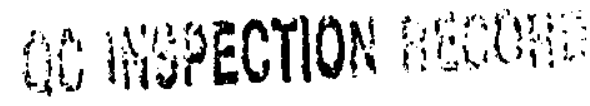




\section{HNF -4277 \\ REVISION 0}

5.8.76 CONNECT a thermocouple probe to the intrinsic side of top thermocouple module (MTL 3081) in the Intrinsic Safe Panel. (This will simulate pump temperature.)

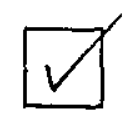

5.8.77 WARM the connected thermocouple probe.

5.8.78 VERIFY Data Table Access Module (screen 25)displays a changed temperature.
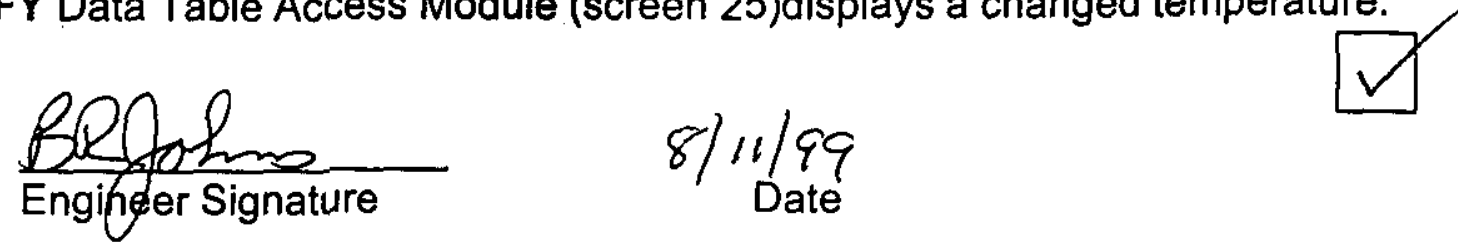

5.8.79 ALLOW the connected probe to return to ambient temperature.

5.8.80 CONNECT a thermocouple probe to the second thermocouple module in the Intrinsic Safe panel. (This will simulate jumper temperature.)

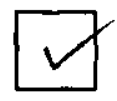

5.8.81 WARM the thermocouple probe.

5.8.82 VERIFY Data Table Access Module (screen 25)displays a changed temperature

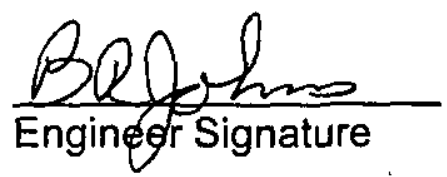

$$
\begin{gathered}
8 / 1199 \\
\text { Date }
\end{gathered}
$$

5.8.83 ALLOW SALW-TE-6002K to return to ambient temperature.

\section{RECIRCULATION FLUSH PRESSURE SIGNAL TO PLC}

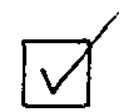

5.8.84 CONNECT a current source to points RFPT+ and RFPT- at the intrinsic side terminal board in the Intrinsic Safe panel.

5.8.85 SET the current source to $20 \mathrm{~mA}$.

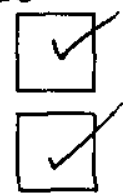

5.8.86 VERIFY an alarm on the DTAM for High Recirc. Flush Pressure(alarm \& screen 139) and strobe flashes.

5.8.87 ACKNOWLEDGE alarm.

5.8.88 SET the current source to $4 \mathrm{~mA}$.

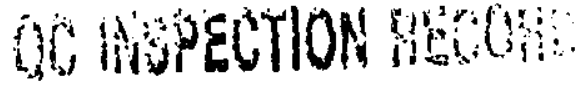


5.8.89 VERIFY the High Recirc. Flush Pressure alarm clears on the DTAM.

5.8.90 DISCONNECT the current source.

\section{JUMPER FLUSH PRESSURE SIGNAL TO PLC}

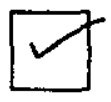

5.8.91 CONNECT a current source to points JFPT+ and JFPT- at the intrinsic side terminal board in the Intrinsic Safe panel.

5.8.92 SET the current source to $12.5 \mathrm{~mA}$.

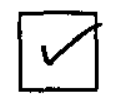

5.8.93 VERIFY an alarm on the DTAM for High Flush Pressure(alarm 3, screen 103) and strobe flashes and the BLUE light on the instrument panel is $O N$.

\subsubsection{ACKNOWLEDGE alarm.}

5.8.95 SET the current source to $4 \mathrm{~mA}$.
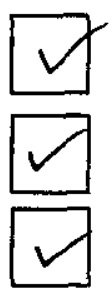

5.8.96 VERIFY the High Flush Pressure alarm clears on the DTAM and the BLUE light turns OFF.

5.8.97 DISCONNECT the current source.

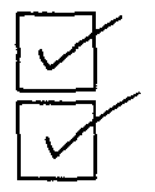

5.8.98 Engineer VERIFY that section 5.8 is complete by SIGNING below.

$$
\begin{gathered}
\text { * See exceptions } 13 \text { and } 14 . \text { Brj } \\
\text { Engineer Signature } \\
\begin{array}{c}
8 / 13 / 99 \\
\text { Date }
\end{array}
\end{gathered}
$$

5.8.99 Quality Control Inspector VERIFY that section 5.8 is complete by signing below.

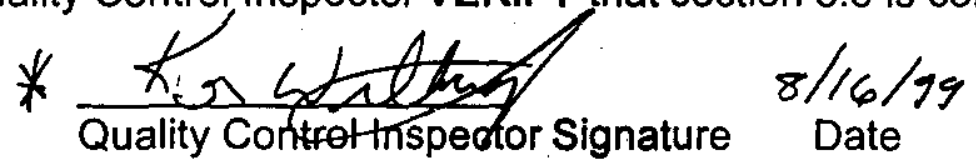

\subsection{3}

Go horetlon netom 
5.9 VERIFY DATA TABLEACCESS MODULE PISCRETE SIGNAL INPUTS

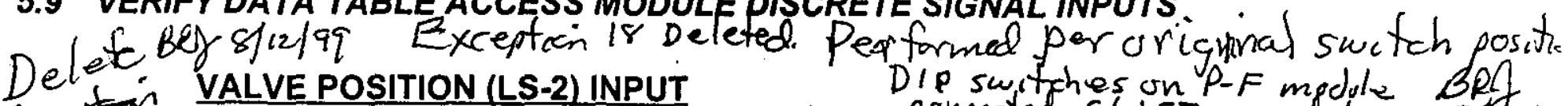

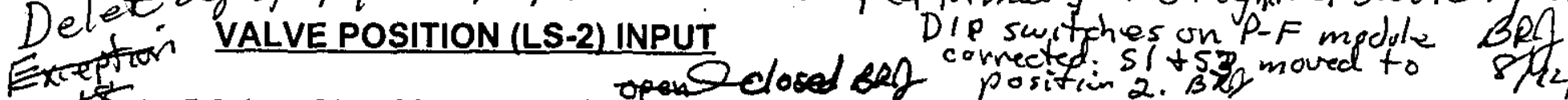
Bff ${ }^{+8}$ 5.9.1 CONNECT a normally etosed-switch across the LS-2+ and LS-2-and a normally 8949 . cto sedopent switch across the LS-1+ AND LS-1-points on the intrinsic safe terminal board in the fतll9 Intrinsic Safe panel.

5.9.2 VERIFY the JR-1 valve indicates "norm" at the Data Table Access Module(screen 42).

Delete 3 of $\$ 12 / 99$

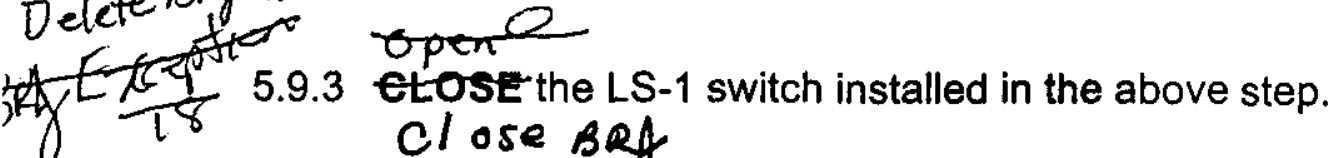

close BRy

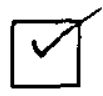

5.9.4 VERIFY the JR-1 valve indicates "NON-PROCESS" at the Data Table Access Module.

Delete BAS 1112194

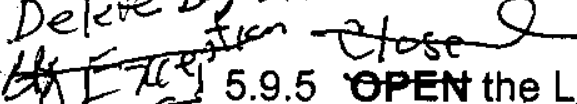

5.9.5 OPEN the LS-2 switch.

Open $B R$ R

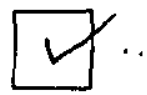

5.9.6 VERIFY the JR-1 valve still indicates "NON-PROCESS" at the Data Table Access

Module.

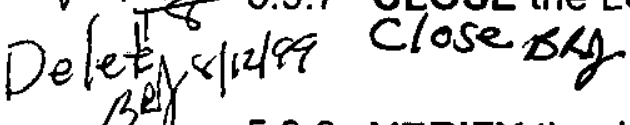

Open peg

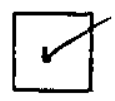

5.9.8 VERIFY the JR-1 valve indicates " norm" at the Data Table Access Module.

5.9.9 REMOVE the switches.
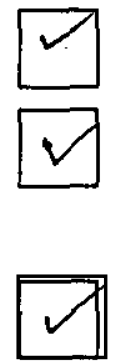

\section{LOW PRESSURE INTERLOCK (PS-1) INPUT}

5.9.10 CONNECT a normally closed switch across points PS-1-NO and PS-1-1(H) at the intrinsic safe terminal board in the Intrinsic Safe panel and a normally open switch across MR1 and 120 vac $8<$ \& 1199 pump motor starter.

5.9.11 VERIFY the GREEN light on the instrument panel is ON.

5.9.12 CLOSE the MR-1 switch.
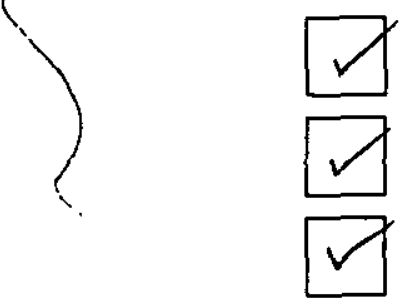

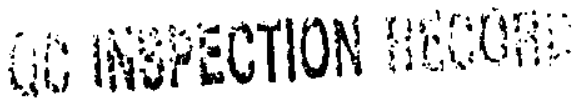


5.9.13 VERIFY the RED light on the instrument panel is ON and the GREEN light is OFF.

5.9.14 OPEN the PS-1 switch.

5.9.15 VERIFY that the amber light on the instrument panel turns ON 30 seconds-after the Exception is opened and a "XFR Pressure LOW" alarm (alarm 1, screen 101) occurs at the DTA
affer 30 seconds delay.

$16 \quad 5.9 .16$ ACKNOWLEDGE alarms at Data Table Access Module.

5.9.17 CLOSE the PS-1 switch to clear the alarm and turn OFF amber light.

5.9.18 REMOVE the two switches.

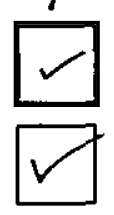

\section{HIGH PRESSURE INTERLOCK (PS-1-1) INPUT}

5.9.19 CONNECT a normally closed switch at points PS-1-NC and PS-1-1(H) at the intrinsic safe terminal board in the Intrinsic Safe panel.

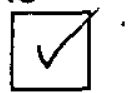

5.9.20 OPEN the switch across the PS-1-1 points.

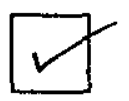

5.9.21 VERIFY a "XFR Pressure HIGH" alarm (alarm 2, screen 102) at the DTAM after a 3 second delay.

5.9.22 ACKNOWLEDGE the alarm.

5.9.23 DISCONNECT the switch.

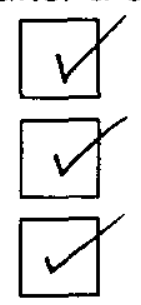

Exception

\section{RECIRCULATION FLOWMETER TEST INPUT}

5.9.24 PLACE a force (rung 5:28) on the motor permissive if necessary to ensure a true

17 logic.

to part If

steps

5.9.25 ENSURE the Controlotron in the Water Cabinet is programmed.

5.9 .24

to

$5,9,34$ control and display unit.

5.9.26 CONFIGURE SALW-FI-6001K (PMP RECIRC FLOW) to receive signals from a 


\section{HNF-4277 \\ REVISION 0}

5.9.27 CONFIGURE the control and display unit to simulate flow signals using the Installation, Diagnostics, Test/Control Mode, AN CAL function.

5.9.28 APPLY power to the Controlotron.

5.9.29 SIMULATE a flow signal of $0.6 \mathrm{gpm}$ with the control and display unit.

5.9.31 SIMULATE a flow signal of $0.4 \mathrm{gpm}$ with the control and display unit.
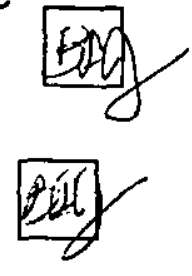
5.9.30 VERIFY no "RECIRCULATION FAILURE" alarm (alarm 21, screen 121).
5.9.29 SIMULATE a flow signal of $0.6 \mathrm{gpm}$ with the control and display unit.

5.9.32 VERIFY Jet Pump recirculation line low flow alarm K21, "RECIRCULATION FAILURE" annunciates at the Data Table Access Module after a 30 seconds delay.

5.9.33 RESTORE SALW-FI-6001K to its original configuration.

5.9.34 REMOVE any forces on the software logic.

\section{DILUTION TANK LOW LEVEL INPUT}

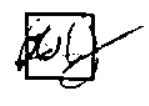

5.9.35 PLACE a normally closed switch across terminal points DIL-L and CKT5H-A on terminal board TB4 in the Instrument Cabinet.

5.9.36 VERIFY no dilution tank low level alarm on the DTAM (alarm 35, screen 135).

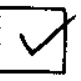

\footnotetext{
5.9.36VERIFY no dilution tank low level alarm on the DTAM (alarm 35, screen 135).
}

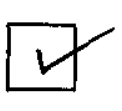

5.9.37 OPEN the switch at TB4.

5.9.38 VERIFY a dilution tank low level alarm on the DTAM.

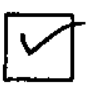

5.9.39 ACKNOWLEDGE the alarm.

5.9.40 CLOSE the switch.

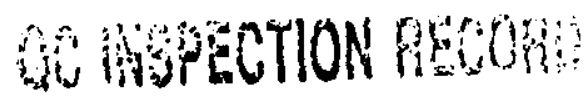


5.9.41 VERIFY alarm clears.

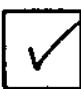

5.9.42 DISCONNECT the switch.

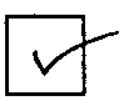

\section{FLAMMABLE GAS MONITOR INPUT}

5.9.43 CONNECT a normally closed switch to points FGM and CKT5H-A on terminal board TB 4 in the instrument cabinet.

5.9.44 VERIFY no FGM interlock alarm on the DTAM (alarm 22, screen 122).

5.9.45 OPEN the switch.

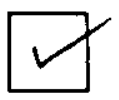

5.9.46 VERIFY an FGM alarm on the DTAM.

5.9.47 ACKNOWLEDGE the alarm.

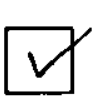

5.9.48 CLOSE the switch.

5.9.49 VERIFY the FGM alarm clears.

5.9.50 LEAVE the switch connected for the Heat Trace check.

\section{HEAT TRACE CONTROL FOR PUMP AND JUMPER}

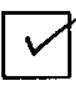

5.9.51 VERIFY that heat trace relays HT-1 and HT-2 are deenergized by checking for zero voltage across points 2 and 7 at each relay.

5.9.52 VERIFY zero voltage at TB12 between $H T-1$ and CKT3-N.

5.9.53 FORCE software to actuate relays HT-1 and HT-2.

5.9.54 CHECK for 120vac at TB-12, points HT-1 and CKT3-N.

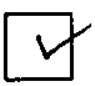

5.9.55 OPEN the FGM switch.

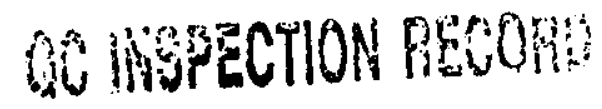


5.9.57 REMOVE the software forces.

5.9.58 REMOVE the switch.

5.9.59 Engineer VERIFY that section 5.9 is complete by SIGNING below.

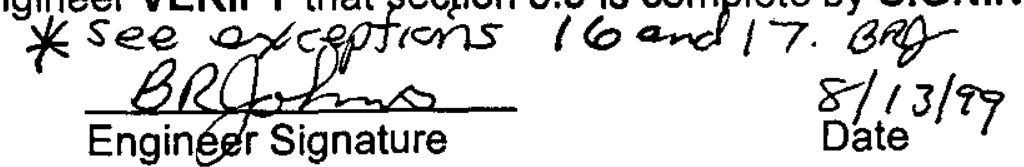

5.9.60 Quality Control Inspector VERIFY that section 5.9 is complete by signing below.

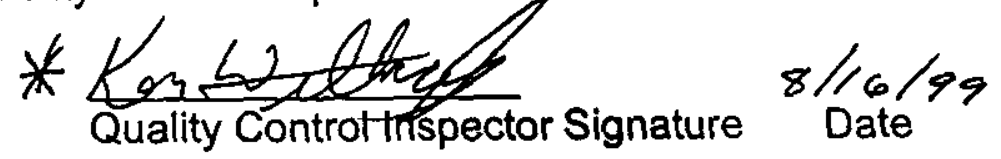




\subsection{CHECK HEATERS AND AIR CONDITIONER}

5.10.1 TURN the heater ON in the air compressor cabinet. Set the thermostat high enough to allow the unit to operate.

5.10.2 RESET the thermostat to approximately 40 degrees $F$ to allow the unit to turn OFF.

5.10.3 TURN the fan thermostat switch low to allow the fan in the air compressor cabinet to run.

5.10.4 RESET the fan switch to approximately 90 degrees.

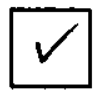

5.10.5 TURN the heater ON in the WFIE cabinet. Set the thermostat high enough to allow the unit to operate.

5.10.6 RESET the thermostat to approximately 40 degrees $F$ to allow the heater to turn OFF.

5.10.7 TURN the heater ON in the Water cabinet. Set the thermostat high enough to allow the unit to operate.

5.10.8 RESET the thermostat to approximately 40 degrees $F$ to allow the heater to turn

OFF.

5.10.9 TURN the heater $O N$ in the Instrument cabinet. Set the thermostat high enough to allow the unit to operate.

5.10.10 RESET the thermostat to approximately 40 degrees $F$ to allow the heater to turn OFF.

5.10.11 TURN ON the air conditioner in the Instrument cabinet. If necessary, remove the front grill on the unit and adjust the temperature setting lower to get the unit to operate.

5.10.12RESET the temperature setting to approximately 90 to 95 degrees.

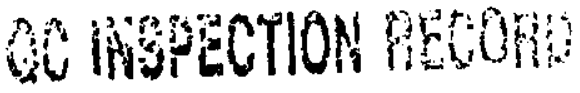
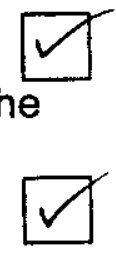


\section{HNF -4277 \\ REVISION 0}

5.10.13 Engineer VERIFY that section 5.10 is complete by SIGNING below.

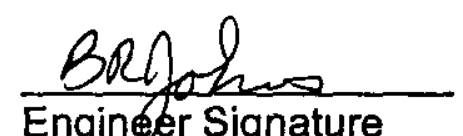

Engineer Signature
$8 / 12199$

Date

5.10.14 Quality Control Inspector VERIFY that section 5.10 is complete by signing below.

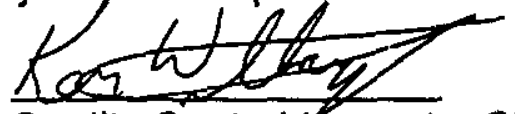

Quality Control Inspector Signature
$8 / 12 / 79$

Date 


\section{HNF-4277 \\ REVISION 0}

5.11 LEAK DETECTION INTERLOCK CHECK (Complete Leak Detector CGI Forms during this ( section.)

5.11.1 Set up two buckets for leak detector testing.

NOTE - $\quad$ A supply of water needs to be available to pour into the buckets during testing.

- $\quad$ Pump operation will be simulated during the remainder of the AंTP.

\section{WARNING}

Energized circuits and leads are contained inside the cabinet. Observe appropriate electrical. Comply with WHC-CM-1-10, WKS-15, ELECTRICAL WORK SAFETY to avoid personnel electrical shock hazards.

5.11.2 PERFORM or VERIFY performed the CGI dedication for the leak detector relays per HNF-4275 and WTF-1-17 and WTF-30-15.

5.11.3 CONNECT a leak detector probe to the primary leak detector terminals at TB11 in the Instrument Cabinet, points SD-1A, SD-1B, SA-1A, and SA-1B.

5.11.4 VERIFY no primary leak detector alarms at the DTAM (alarms 6 and 7, screens 106 and 107).

5.11.5 PLACE the leak detector assembly in a bucket of water.

5.11.6 VERIFY a leak detector leak and trouble alarm for the primary leak detector is received at the DTAM (alarm 6 ) after a 3 second delay.

5.11.7 ACKNOWLEDGE the Leak Detector Alarm at the Data Table Access Module.

5.11.8 REMOVE the leak detector assembly from the bucket and allow the water to drain off the assembly into the bucket.

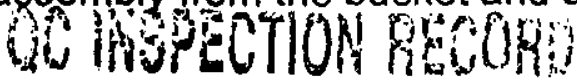


5.11.9 VERIFY the leak detector alarms clear at the DTAM.

5.11.10 DISCONNECT one of the "SD" wires going to the probe.

5.11.11 VERIFY trouble alarm 7 occurs.

5.11.12 ACKNOWLEDGE the alarm. 5.11.13 BHSONAEeT the probe. Recomnectwine, verify trouble dann
Clears.

5.11.14 CONNECT a leak detector probe to leak detector \#f terminals at TB11 in the Instrument Cabinet, points SD-2A, SD-2B, SA-2A, and SA-2B. 1 BRg $8 / 4 / 99$

5.11.15 VERIFY no leak detector \# 2 alarms at the DTAM (alarms 18 and 19 , screens 118 and 119).

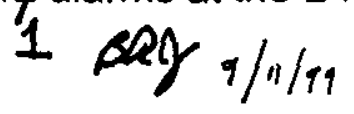

5.11.16 PLACE the leak detector assembly in a bucket of water.

5.11.17 VERIFY a leak detector leak and trouble alarm for leak detector \#1 is received at the DTAM.

5.11.18 ACKNOWLEDGE the Leak Detector Alarm at the Data Table Access Module.

5.11.19 REMOVE the leak detector assembly from the bucket and allow the water to drain off the assembly into the bucket.

5.11.20 VERIFY the leak detector alarms clear at the DTAM.

5.11.21. DISCONNECT one of the "SD" wires going to the probe.

5.11.22 VERIFY trouble alarm 19 occurs.

5.11.23 ACKNOWLEDGE the alarm.

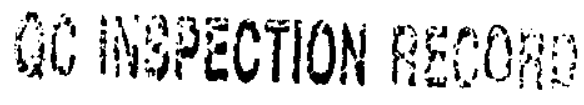


HNF-4277

REVISION 0

Exception

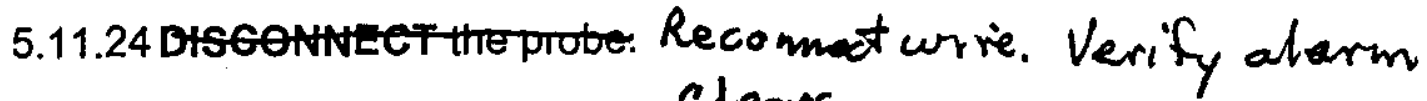
Clears.

minis

B.

5.11.25 DISCONNECT the leak detector assembly form TB11. NHA

PIT

5.11.26 Engineer VERIFY that section 5.11 is complete by SIGNING below.

See exception 28

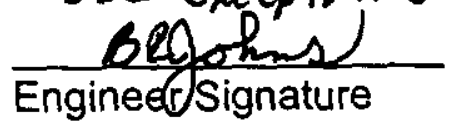

$$
\text { q111 } 199
$$

5.11.27 Quality Control Inspector VERIFY that section 5.11 is complete by signing below.

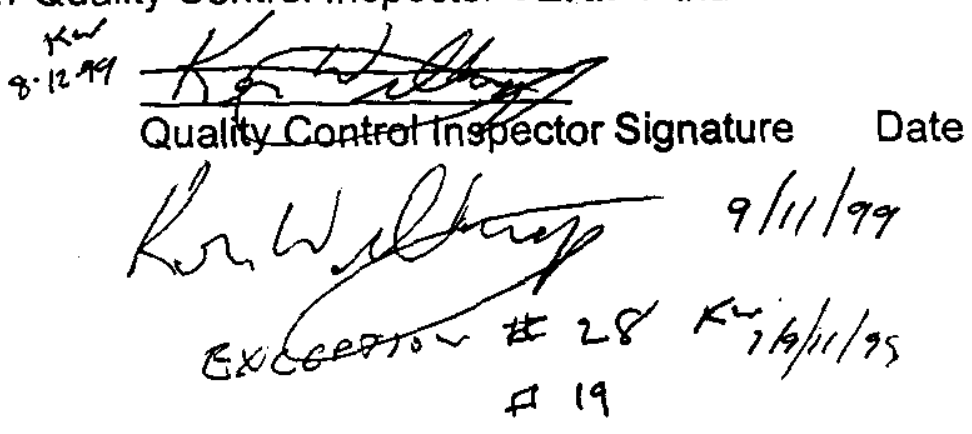

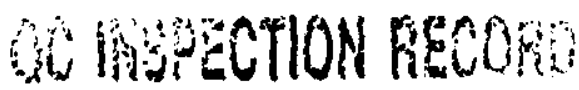

IORK ORDER

$2 H 9903385$

PAGE A43

PAGE $177 \quad$ OF 


\subsection{PLC OUTPUTS}

\section{JET PUMP START AND DILUTION OUTPUTS}

5.12.1 CONNECT a voltmeter across terminals MS- 1 and $120 \mathrm{vac}$ COM at the terminal block in the jet pump motor starter and across terminals DIL-P and $120 \mathrm{~N}$ at TB4 in the Instrument Cabinet.

5.12.2 FORCE software for an output (rung 7:0) on 0:11/2 (address N60:31/2).

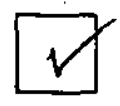
5.12 .3 VERIFY $120 \mathrm{vac}$ on both voltmeters.
5.12.4 REMOVE the software force and VERIFY zero volts on both voltmeters.
5.12.5 DISCONNECT the voltmeters.

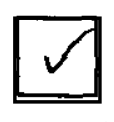

\section{STROBE, BUZZER AND LIGHT OUTPUTS}

5.12.6 USE software forces to verify the strobe, buzzer on pump shut down.

5.12.7 PLACE a force at subroutine 18 , rung 11 to turn ON the strobe and buzzer.

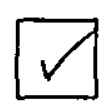

5.12.8 ACKNOWLEDGE the alarms.

5.12.9 REMOVE the software force.

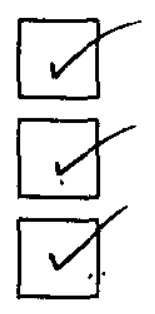




\section{PART II}

NOTE: This part of the ATP will be performed when the PIC skid is in the Interim Stabilization maintenance shop. Verify prerequisites are completed before proceeding, which includes connection of the jumper and pump assembly. A computer is set up and connected to the skid to simulate the OCS for " $U$ " farm. Perform the following for Part II set up.

\section{SKID AND PUMP SET UP:}

- $\quad$ Set up skid "K" and connect to pump, jumper and recirculation assembly including all the wiring to the switches and transducers. Test gauges are to be installed on the jumper assembly for suction and discharge pressure verification. Actual piping, tubing or wiring to be used in the field need not be used for the hookups if not available. Reference $\mathrm{H}-14-103530$ for connections to the skid.

- Provide an FGM for skid " $K$ " and connect just the air line and interlock wiring. Actual tubing and wiring to be used in the field need not be used for this test set up if not available.

- Connect two leak detector probes to the skid. If the actual leak detector probes to be used in the field are not available, then any similar type probes can be used.

- Connect the computer to the skid PLC for the Operator Control Station (OCS).

Exception \#22 Finjsh section 5.4 for Controlotron. Check section 5.5 for programming. 374 5.13 VERIFY DATA TABLE ACCESS MODULE AND OPERATOR CONTROL STATION ANALOG i16 69 INPUT SIGNALS

5.13.1 PREPARE the Water Tank Level Transmitter SALW-LT-6003K for test signals by PERFORMING the following:

5.13.2 ENSURE valve SALW-V-6029K, located in the bottom of SALW-PNL-6003K (WATER TANK ENCL), is CLOSED.

5.13.3 ENSURE valve SALW-V-6031K, located in the bottom of SALW-PNL-6003K (WATER TANK ENCL), is CLOSED.

$$
\text { (minimum range) org } 9 / 8 / 99
$$

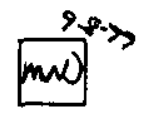

5.13.4 CONNECT 0-50" test Manometer pressure source to the HIGH PRESSURE vent/test port of the level transmitter SALW-LT-6003K.

5.13.5 VERIFY the LOW PRESSURE vent/test port of the level transmitter SALW-LT-6003K is OPEN to atmosphere.

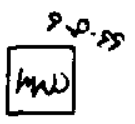

5.13.6 ADJUST the test Manometer on the SALW-LT-6003K to a pressure of 31" Water Gauge ( $\pm 1 "$ ). 
5.13.7 RECORD the following:

\begin{tabular}{|c|c|}
\hline $\begin{array}{c}\text { OPERATOR CONTROL STATION } \\
\text { WATER TANK LEVEL } \\
\text { (RANGE: } 28.5 \text { TO } 33.5 \text { inches) }\end{array}$ & $\begin{array}{c}\text { DATA TABLE ACCESS MODULE } \\
\text { WATER TANK LEVEL } \\
\text { (RANGE: 28.5 TO } 33.5 \text { Inches) }\end{array}$ \\
\hline 31.2 inches & 31.1 inches \\
\hline
\end{tabular}

NOTE - Alarm should annunciate between 11.75" and 12.75" Water Gauge.

5.13.8 VERY SLOWLY DECREASE the Level Transmitter test Manometer pressure UNTIL the Data Table Access Module "PIC WATER LOW" alarm (alarm 9) annunciates.

5.13.9 VERIFY that the Water Tank Low Level alarm is displayed at the Operator Control Station.

5.13.10 ACKNOWLEDGE the Water Tank Low Level alarm at the Operator Control Station and at the Data Table Access Module.

5.13.11 OBSERVE the Operator Control Station and Data Table Access Module AND RECORD the water tank level readings below:

\begin{tabular}{|c|c|}
\hline $\begin{array}{c}\text { OPERATOR CONTROL STATION } \\
\text { WATER TANK LEVEL } \\
\text { (RANGE } 11.75 \text { to } 12.75 \text { inches Water } \\
\text { Gauge) }\end{array}$ & $\begin{array}{c}\text { DATA TABLE ACCESS MODULE } \\
\text { WATER TANK LEVEL } \\
\text { (RANGE 11.75 to 12.75 inches Water } \\
\text { Gauge) }\end{array}$ \\
\hline 12.1 inchss & 12.1 inches \\
\hline
\end{tabular}

5.13.12 SLOWLY INCREASE the Level Transmitter test Manometer pressure to 15.5" Water Gauge.

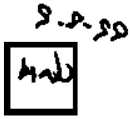

5.13.13 OBSERVE the Operator Control Station and Data Table Access Module AND RECORD the water tank level readings below: 
HNF-4277

REVISION 0

\begin{tabular}{|c|c|}
\hline $\begin{array}{c}\text { OPERATOR CONTROL STATION } \\
\text { WATER TANK LEVEL } \\
\text { (RANGE: } 14.5 \text { to } 16.5 \text { inches) }\end{array}$ & $\begin{array}{c}\text { DATA TABLE ACCESS MODULE } \\
\text { WATER TANK LEVEL } \\
\text { (RANGE 14.5 to 16.5 inches) }\end{array}$ \\
\hline 15.5 inchss & 15.5 inches \\
\hline
\end{tabular}

5.13.14 VERIFY that the Water Tank Low Level alarm CLEARS at the Operator Control Station.

5.13.15REMOVE the test manometer from the SALW-LT-6003K high pressure vent/test port, AND RE-INSTALL vent plugs.

5.13.16 RESTORE the Water Tank Level Transmitter SALW-LT-6003K by PERFORMING the following:

5.13.17 OPEN valve SALW-V-6029K, located in the bottom of SALW-PNL-6003K (WATER TANK ENCL).

5.13.18 OPEN valve SALW-V-6031K, located in the bottom of SALW-PNL-6003K (WATER TANK ENCL).

\section{WEIGHT FACTOR TEST}

5.13.19 VERIFY that NO Programmable Logic Controller input signals are FORCED and that the forcing function is DISABLED.

$$
\text { (minimum vange) BRf }
$$

5.13.20 CONNECT the 0-500" Water Gauge test Manometer pressure source to the HIGH PRESSURE dip tube on the side of the "WFIE Cabinet".

5.13.21 ENSURE SALW-V-6001K is CLOSED.

5.13.22 ENSURE SALW-V-6005K is OPEN. 
5.13.23 ENSURE SALW-V-6006K is OPEN.

5.13.24 ENSURE adjustment valves on SALW-FIV-6002K, SALW-FIV-6003K, SALW-FIV-6004K are CLOSED.

5.13.25ENSURE SALW-WFT-6002K EQUALIZING valve located on SALW-V-6036K 3-Valve Manifold in cabinet SALW-PNL-6002K (WFIE Cabinet) is CLOSED.

5.13.26 ENSURE the LOW side and HIGH side isolation valves, located on SALW-V-6036K 3-Valve Manifold in cabinet SALW-PNL-6002K (WFIE Cabinet) are OPEN.

5.13.27 SET the test Manometer to $125^{\prime \prime}$ Water Gauge.

5.13.28 OBSERVE Operator Control Station and Data Table Access Module AND RECORD the Weight Factor on the table below.

\begin{tabular}{|c|c|}
\hline $\begin{array}{c}\text { OPERATOR CONTROL STATION } \\
\text { WEIGHT FACTOR READING } \\
\text { (RANGE 120 to } 130 \text { inches) }\end{array}$ & $\begin{array}{c}\text { DATA TABLE ACCESS MODULE } \\
\text { WEIGHT FACTOR READING } \\
\text { (RANGE 120 to 130 inches) }\end{array}$ \\
\hline 125.4 inches & 125,4 inches \\
\hline
\end{tabular}

5.13.29 BLEED off pressure from the manometer.

5.13.30 DISCONNECT the 0-500" test Manometer pressure source.

5.13.31 CLOSE SALW-V-6006K.

5.13.32 OPEN SALW-WFT-6002K equalizing valve, located on SALW-V-6036K 3-Valve Manifold in cabinet SALW-PNL-6002K (WFIE Cabinet).

5.13.33 CLOSE the LOW side and HIGH side isolation valves, located on SALW-V-6036K 3-Valve Manifold in cabinet SALW-PNL-6002K (WFIE Cabinet). 
DISCHARGE PRESSURE TEST

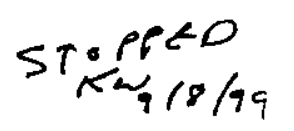

5.13.34 ENSURE Pump recirculation apparatus is filled with water AND configured to

Eef circulate water through the saltwell Jet Pump jumper.

5.13.35 PLACE JR-1 valve in the PROCESS position.

5.13.36 At the discretion of the Engineer, INSTALL temporary interlock jumpers, OR INITIATE a software force on pump permissive interlocks for equipment not installed or out of service.

5.13.37 USING the Data Table Access Module, START the Jet Pump.

5.13.38 RECORD the following pressures on the table below:

\begin{tabular}{|c|c|c|c|c|}
\hline $\begin{array}{c}\text { SALW-PI-601.2K } \\
\text { JET PUMP } \\
\text { SUCTION } \\
\text { PRESSURE }\end{array}$ & $\begin{array}{c}\text { TEST } \\
\text { GAUGE } \\
\text { PI-1 }\end{array}$ & $\begin{array}{c}\text { DTAM } \\
\text { DISCHARGE } \\
\text { PRESSURE }\end{array}$ & $\begin{array}{c}\text { SALW-PI-6011K } \\
\text { JET PUMP } \\
\text { DISCHARGE } \\
\text { PRESSURE }\end{array}$ & $\begin{array}{c}\text { TEST } \\
\text { GAUGE } \\
\text { PI-2 }\end{array}$ \\
\hline 44.9 ps: & 45,0 ssi & 79 psi & 80.2 ps: & $80.3 p^{\circ} ;$ \\
\hline
\end{tabular}

5.13.39 Using the Data Table Access Module, STOP the Jet Pump.

\section{THERMOCOUPLE TEST}

5.13.68 WARM thermocouple SALW-TE-6004K, located in the Instrument Enclosure.

5.13.69 VERIFY Data Table Access Module and Operator Control Station display a changed temperature (Operator Control Station and Data Table Access Module should match $\pm 2^{\circ} \mathrm{F}$ ).

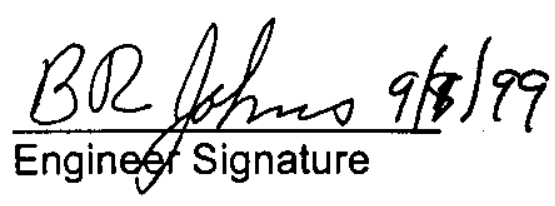

Date 
5.13.70 ALLOW SALW-TE-6004K to return to ambient temperature.

5.13.71 WARM thermocouple SALW-TE-6003K, located in SALW-PNL-6001K INSTRUMENT AIR ENCLOSURE. $\quad 1$ PR R $9 / 8 / 99$

5.13.72 VERIFY Data Table Access Module and Operator Control Station DISPLAY a changed temperature. (Operator Control Station and Data Table Access Module should match $\pm 2^{\circ} \mathrm{F}$ ).

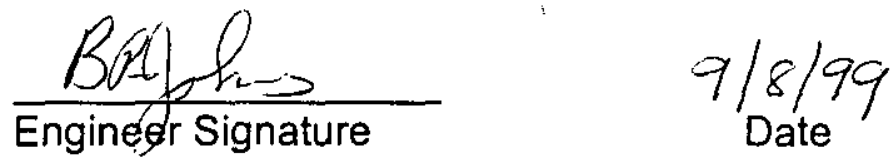

5.13.73 ALLOW SALW-TE-6003K to return to ambient temperature.

$$
1 \text { beg } 9 / 2 / 91
$$

5.13.74 WARM thermocouple SALW-TE-600 $\mathrm{K}$, located on the Jet Pump.

$$
2 \operatorname{sog} 9 / 8 / 99
$$

5.13.75 VERIFY Data Table Access Module and Operator Control Station DISPLAY a changed temperature. (Operator Control Station and Data Table Access Module should match $\left.\pm 2^{\circ} \mathrm{F}\right)$.

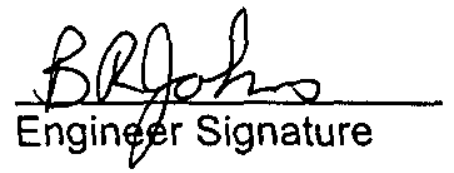

$$
9 / 8 / 99
$$

5.13.76 ALLOW SALW-TE-6001K to return to ambient temperature.

$$
2 \text { BRg } 9 / 8199
$$

5.13.77 WARM thermocouple SALW-TE-6002K (Jet Pump over temperature thermocouple located on the saltwell Jet Pump jumper). $\quad 3 \mathrm{BRy} 9 / 8 / 99$

5.13.78 VERIFY Data Table Access Module and Operator Control Station DISPLAY a changed temperature (Operator Control Station and Data Table Access Module should match $\left.\pm 2^{\circ} \mathrm{F}\right)$.

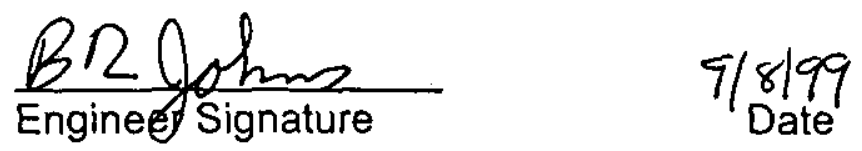

5.13.79 ALLOW SALW-TE-6002K to return to ambient temperature. 
HNF-4277

REVISION 0

5.13.80 REMOVE any jumpers or forces NOT required for the next test section.

ind

5.13.81 Engineer VERIFY that section 5.13 is complete by SIGNING below.

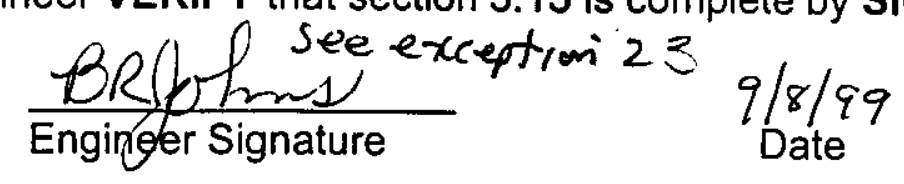

5.13.82 Quality Assurance Inspector VERIFY that section 5.13 is complete by signing below.

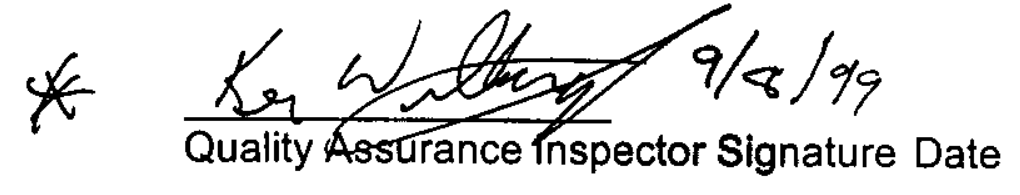

* Sec Excretion \#23 kw/slo,

PAGE A51 


\section{HNF-4277 \\ REVISION 0}

\subsection{VERIFY DATA TABLE ACCESS MODULE AND OPERATOR CONTROL STATION DISCRETE SIGNAL INPUTS}

Connect the lap top computer to the PLC to monitor the logic as necessary.

\section{VALVE POSITION TEST}

5.14.1 ENSURE the JR-1 valve is in the PROCESS position.

5.14.2 VERIFY the JR-1 valve indicates "norm" at the Data Table Access Module AND "PROCESS" position at the Operator Control Station.

NOTE: The DIP switches on the Pepperl-Fuchs module in the Intrinsic Safe panel may require changing to get the "norm" indication.

5.14.3 PLACE the JR-1 valve in the FLUSH position.

5.14.4 VERIFY the JR-1 valve indicates "NON-PROCESS" at the Data Table Access Module AND "FLUSH" position at the Operator Control Station.

5.14.5 PLACE the JR-1 valve in the PRIME position.

5.14.6 VERIFY the JR-1 valve indicates "NON-PROCESS" at the Data Table Access Module AND "PRIME" position at the Operator Control Station.

\section{FLUSH LINE PRESSURE TEST}

5.14.7 PLACE the JR-1 valve in the PROCESS position.

5.14.8 VERIFY a water supply is connected to the jumper flush hose.

5.14.9 ENSURE Pump recirculation apparatus is filled with water AND configured to circulate water through the saltwell Jet Pump jumper.

5.14.10 At the discretion of the Engineer, ENSURE temporary interlock jumpers, OR software forces have been installed on pump permissive interlocks for equipment not installed or out of service. 
5.14.12 VERIFY the Jet PUMP OPERATION at the Operator Control Station.

5.14.13 ACTUATE pressure transducer SALW-PT-6014K (old name "PS-2") by PRESSURIZING the flush line with water.

5.14.14 VERIFY the Jet Pump IMMEDIATELY shuts down at the Data Table Access Module and Operator Control Station.

5.14.15 VERIFY flush line high pressure alarm *3, "Flush Pressure $\mathrm{HI}$ " annunciates at the Data Table Access Module and Operator Control Station.

5.14.16 SHUT OFF the water supply to the flush line.

5.14.17 CYCLE the JR-1 valve to CLEAR the flush line high pressure alarm.

5.14.18REMOVE wire to pressure transducer to verify that a loss of signal alarm occurs (alarm 16). on the DTAM. BRg $9 / 8 / 99$

5.14.19 ACKNOWLEDGE the alarm.

5.14.20 RECONNECT the wire. 


\section{HNF-4277 \\ REVISION 0}

5.14.26 VERIFY the Jet Pump shuts down in approximately thirty $(30)$ seconds $( \pm 5$ seconds).

5.14.27 VERIFY transfer line low pressure alarm \#1 "XFR Pressure LOW" annunciates at the Data Table Access Module and Operator Control Station.

5.14.28 ACKNOWLEDGE alarms at Data Table Access Module and Operator Control Station.

NOTE - This test section is performed with jet pump jumper and pump physically mated in the shop on the run-in stand.

\section{HIGH PRESSURE INTERLOCK}

5.14 .29

PLACE the JR- 1 valve in the PRIME position.

5.14.30 IF a water ram will be used, using skill of the craft CONNECT a water ram to the jet pump jumper AND SLOWLY PRESSURIZE the pump and jumper to 140 psi using water.

5.14.28 IF pump will develop $140 \mathrm{psi}$, START jet pump with JR-2, BYPASS valve and DOV closed.

5.14.29 VERIFY that the "XFR Pressure HIGH" alarms at Data Table Access Module (Alarm ${ }^{\star} 2$ ) and Operator Control Station when pressure reaches $140 \mathrm{psi}( \pm 10 \mathrm{psi})$.

$$
144 \text { p.si: } B A \gamma
$$

5.14.30 ACKNOWLEDGE alarms at Data Table Access Module and Operator Control Station.

\section{RECIRCULATION FLOWMETER TEST}

NOTE: Perform steps 5.9.25 to 5.9.34 in conjunction with the following steps. Step 5.9.24 can be N/A since the Controlotron is connected to the recirc line.

5.14.31 PLACE the JR-1 valve in the PROCESS position.

5.14.32 ENSURE Pump recirculation apparatus is filled with water AND configured to circulate water through the saltwell Jet Pump jumper. 


\section{HNF -4277 \\ REVISION 0}

5.14.33 CONFIGURE SALW-FI-6001K (PMP RECIRC FLOW) to receive signals from a control and display unit.

5.14.34 CONFIGURE the control and display unit to simulate flow signals using the Installation, Diagnostics, Test/Control Mode, AN CAL function.

5.14.35 SIMULATE a flow signal of $0.6 \mathrm{gpm}$ with the control and display unit.

5.14.36 At the discretion of the Engineer, ENSURE temporary interlock jumpers OR software forces have been installed on pump permissive interlocks for equipment not installed or out of service.

5.14.37 USING the Data Table Access Module, START the Jet Pump.

5.14.38 VERIFY the Jet Pump OPERATION at the Operator Control Station.

5.14.39 SIMULATE a flow signal of $0.4 \mathrm{gpm}$ with the control and display unit.

5.14.40 VERIFY the Jet Pump shuts down (after $30 \pm 5 \mathrm{sec}$.) at the Data Table Access Module and Operator Control Station.

5.14.41 VERIFY Jet Pump recirculation line low flow alarm *21, "RECIRCULATION FAILURE" annunciates at the Data Table Access Module and Operator Control Station.

Ack. alarm.

5.14.42 RESTORE SALW-FI-6001K to its original configuration.

5.14.43 CYCLE the JR-1 valve to CLEAR the Jet Pump recirculation line low flow alarm. 


\section{REVISION 0}

\section{RECIRCULATION FLUSH LINE PRESSURE TEST}

5.14.44 PLACE the JR-1 valve in the PROCESS position.

5.14.45 VERIFY a water supply is connected to the recirculation flush line.

5.14.46 ENSURE Pump recirculation apparatus is filled with water AND configured to circulate water through the saltwell Jet Pump jumper.

5.14.47 At the discretion of the Engineer, ENSURE temporary interlock jumpers OR software forces have been installed on pump permissive interlocks for equipment not installed or out of service.

5.14.48 USING the Data Table Access Module, START the Jet Pump.

5.14.49 VERIFY the Jet Pump OPERATION at the Operator Control Station.

5.14.50 ACTUATE pressure transducer SALW-PT-6013K (RECIRC FLUSH PRESS) by PRESSURIZING the recirculation flush line with water.

5.14.51 VERIFY the Jet Pump IMMEDIATELY shuts down at the Data Table Access Module and Operator Control Station.

Add Alam Ack. step BRy here $3 R$ fo

5.14.52 VERIFY recirculation flush line high pressure alarm *39, "RECIRC FLUSH PRSS $\mathrm{HI}$ " annunciates at the Data Table Access Module and Operator Control Station.

5.14.53 SHUT OFF the water supply to the recirculation flush line.

5.14.54. CYCLE the JR-1 valve to CLEAR the recirculation flush line high pressure alarm. 
NF -4277

REVISION 0

5.14.55 REMOVE any jumpers or forces NOT required for the next test section.

ind

5.14.56 REMOVE a wire to the pressure transducer on the flush line to verify a loss of signal alarm (alarm 14) on the DTAM.

5.14.57 ACKNOWLEDGE the alarm.

5.14.58 RECONNECT the wire.

Delete Brag

पार

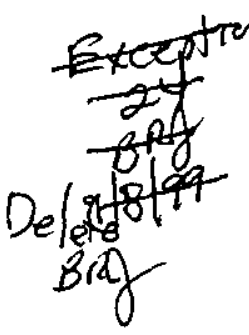

5.14.59 VERIFY the alarm clears.

5.14.60 Engineer YERIFY that section 5.14 is complete by SIGNING below.

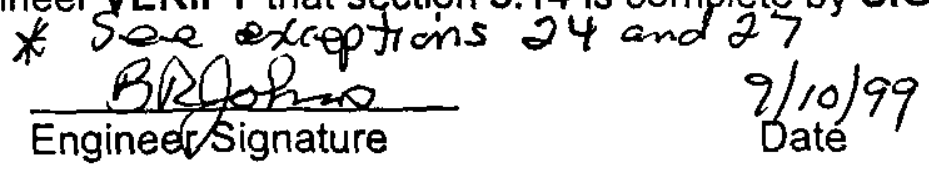

5.14.61 Quality Assurance Inspector VERIFY that section 5.14 is complete by signing below.

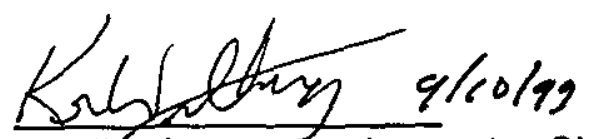

Quality Assurance Inspector Signature Date

* Kw q/10/ag ExT 2y,2).

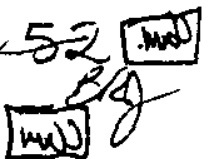

mill 
HNF -4277

REVISION 0

\subsection{VERIFY DATA TABLE ACCESS MODULE AND OPERATOR CONTROL STATION MONITOR/ALARM FUNCTIONS}

5.15.1 At the discretion of the Engineer, ENSURE temporary interlock jumpers, OR software forces are in place for uninstalled equipment.

Detoption 25

5.15.2 SET the test manometer on the specific gravity transmitter to $13^{\prime \prime}$ Water Gauge.

5.15.3 ENSURE the following valves are OPEN:

\begin{tabular}{|l|c|}
\hline \multicolumn{1}{|c|}{ Valve Number } & $\checkmark$ \\
\hline SALW-V-6034K & $\checkmark$ \\
\hline SALW-V-6026K & $\checkmark$ \\
\hline SALW-V-6001K & $\checkmark$ \\
\hline SALW-V-6004K & $\checkmark$ \\
\hline SALW-V-6002K & $\checkmark$ \\
\hline
\end{tabular}

5.15.4 ENSURE Pump recirculation apparatus is filled with water AND configured to circulate water through the saltwell Jet Pump.

5.15.5 START the Jet Pump using the Data Table Access Module, AND PLACE the system in automatic.

5.15.6 VERIFY the DIAPHRAGM OPERATED VALVE moves OPEN.

5.15.7 OBSERVE the Operator Control Station and Data Table Access Module AND RECORD the specific gravity readings below:

\begin{tabular}{|c|c|}
\hline $\begin{array}{c}\text { OPERATOR CONTROL STATION } \\
\text { SPECIFIC GRAVITY READING } \\
\text { (RANGE 12.6 to 13.4 inches) }\end{array}$ & $\begin{array}{c}\text { DATA TABLE ACCESS } \\
\text { MODULE SPECIFIC GRAVITY } \\
\text { READING } \\
\text { (RANGE 12.65 to 13.35 inches) }\end{array}$ \\
\hline 13.1 inchss & 13.12 inchs \\
\hline
\end{tabular}


HNF-4277

REVISION 0

5.15.8 VERY SLOWLY DECREASE the test manometer pressure until the Data Table Access Module "SGT LOW" alarm (alarm *13) annunciates.

NOTE, - SALW-PI-6005K pressure is to be recorded in the table below when DOV position indicates fully closed.

5.15.9 VERIFY AND ACKNOWLEDGE the Specific Gravity Low Alarm (Saltwell LOW Level) at the Data Table Access Module and Operator Control Station.

5.15.10RECORD the following:

\begin{tabular}{|c|c|}
\hline PARAMETER & READING \\
\hline $\begin{array}{l}\text { OPERATOR CONTROL STATION } \\
\text { SPECIFIC GRAVITY (RANGE } 3 \text { to 4) } \\
\end{array}$ & 3.5 \\
\hline $\begin{array}{l}\text { DATA TABLE ACCESS MODULE } \\
\text { SPECIFIC GRAVITY (RANGE } 3 \text { to } 4 \text { ) }\end{array}$ & 3.47 \\
\hline $\begin{array}{l}\text { SPECIFIC GRAVITY MANOMETER READING } \\
\text { (RANGE } 3 \text { to } 4 \text { inches Water Gauge) }\end{array}$ & 3.39 \\
\hline $\begin{array}{l}\text { DOV POSITION (\% OPEN) } \\
\text { [RANGE - FULLY CLOSED] }\end{array}$ & $0 \%$ \\
\hline $\begin{array}{l}\text { SALW-PI-6005K PRESSURE } \\
\text { (RANGE } 2 \text { to } 4 \text { psig) } \\
\end{array}$ & Opsi Alarm most \\
\hline
\end{tabular}

5.15.11 VERY SLOWLY INCREASE the test manometer pressure to 10 inches Water Gauge.

5.15.12 OBSERVE the Operator Control Station and Data Table Access Module AND RECORD the specific gravity readings below:

\begin{tabular}{|c|c|}
\hline $\begin{array}{c}\text { OPERATOR CONTROL STATION } \\
\text { SPECIFIC GRAVITY READING } \\
\text { (RANGE } 9 \text { to } 11 \text { inches) }\end{array}$ & $\begin{array}{c}\text { DATA TABLE ACCESS MODULE } \\
\text { SPECIFIC GRAVITY READING } \\
\text { (RANGE 9 to 11 inches) }\end{array}$ \\
\hline 10.0 & 10.11 \\
\hline
\end{tabular}




\section{HNF-4277 \\ REVISION 0}

5.15.13VERIFY that the Specific Gravity Low Alarm CLEARS at the Operator Control Station and at the Data Table Access Module.

5.15.14 VERIFY the Diaphragm Operated Valve moves OPEN.

5.15.15REMOVE any jumpers or forces NOT required for the next test section.

5.15.15REMOVE any jumpers or forces NOT required for the next test section.

5.15.16 SHUT OfF the jet pump using the Data Table Access Module.

5.15.17 Engineer VERIFY that section 5.15 is complete by SIGNING below.

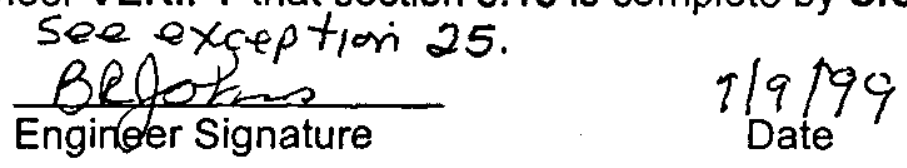

5.15.18 Quality Assurance Inspector VERIFY that section 5.15 is complete by signing below.

$$
\begin{aligned}
& \text { * KrMathug } 9 / 9 / 99 . \\
& \text { \# StE Exceprin } 25 \\
& \text { Kes 9lalo, }
\end{aligned}
$$


5.16 REMOTE SETPOINT CHANGE USING THE OPERATOR CONTROL STATION Exception

5.16.1 PLACE the saltwell jumper JR-1 valve in the PROCESS position.

\section{$\$ 26$} Remove test

manom 2 ter 5.16 .2 ENSURE pump recirculation apparatus

5.16.3 START the Jet Pump using the Data Table Access Module.

5.16.4 SET the "DOV" Specific Gravity setpoint to 8 inches at the Operator Control Station.

5.16.5 VERIFY that the "DOV" Specific Gravity setpoint is 8 inches at the Data Table Access Module AND the Operator Control Station.

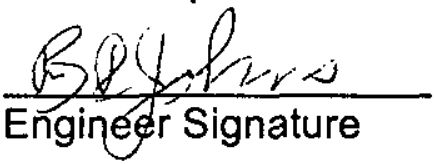

$9 / 9 \sqrt{99}$

5.16.6 SET the "DOV" Specific Gravity setpoint to 6 inches at the Data Table Access Module. 


\section{HNF -4277 \\ REVISION 0}

\subsection{DATA TABLE ACCESS MODULE AND OPERATOR CONTROL STATION}

NOTE - This system is a Proportional Integral Derivative controller for controlling the liquid level in the saltwell screen. The Specific Gravity Transmitter reads unadjusted liquid level once the middle diptube leg is uncovered by declining liquid levels.

The system uses the signal from the Specific Gravity Transmitter as the Process Variable. The controller compares the process variable to the setpoint and adjusts the Diaphragm Operated Valve position accordingly (manipulated variable).

The purpose of this test section is to verify that the Diaphragm Operated Valve trend is toward achieving the setpoint while different process variables are simulated.

\section{DATA TABLE ACCESS MODULE (AUTOMATIC)}

5.17.1 ENSURE the Saltwell Pump and Jumper Assembly, AND the Pumping and Instrumentation Control Skid are configured for AUTOMATIC Diaphragm Operated Valve level control by PERFORMING the following:

5.17.2 SET the test manometer on the Specific Gravity Transmitter to a pressure of 0" Water Gauge.

5.17.3 ENSURE the following valves are OPEN:

\begin{tabular}{|l|c|}
\hline \multicolumn{1}{|c|}{ Valve Number } & $\checkmark$ \\
\hline SALW-V-6034K & $\swarrow$ \\
\hline SALW-V-6026K & $\checkmark$ \\
\hline SALW-V-6001K & $\checkmark$ \\
\hline SALW-V-6004K & $\checkmark$ \\
\hline SALW-V-6002K & \\
\hline
\end{tabular}

5.17.3 PLACE the saltwell jumper JR-1 valve in the PROCESS position.

5.17.4 At the discretion of the Engineer, ENSURE temporary interlock jumpers, OR software forces have been installed on pump permissive interlocks for equipment not installed or out of service. 
HNF-4277

REVISION 0

5.17.5 ENSURE that only alarms "JET PUMP SHUTDOWN" (Alarm 12) and "SGT LOW" (Alarm 13) on the Data Table Access Module are displayed.

5.17.6 ENSURE pump recirculation apparatus is filled with water AND CONFIGURED to circulate water through the saltwell Jet Pump.

5.17.7 START the Jet Pump using the Data Table Access Module.

5.17.8 SET DIAPHRAGM OPERATED VALVE Specific Gravity Controller to AUTO with setpoint of seven (7) inches USING the Data Table Access Module.

5.17.9 SET the test manometer to a pressure of 14" Water Gauge.

5.17.10 VERIFY that the Diaphragm Operated Valve moves to a more OPEN position.

5.17.11 SET the test manometer to a pressure of 6 " Water Gauge.

5.17.12 VERIFY that the Diaphragm Operated Valve moves to a more CLOSED position.

\section{DATA TABLE ACCESS MODULE (MANUAL)}

5.17.13 VERIFY that the MANUAL CONTROL of the Diaphragm Operated Valve is operational by PERFORMING the following steps:

5.17.14 SET the test manometer on the Specific Gravity Transmitter to a pressure of $15^{\prime \prime}( \pm$ 1") Water Gauge.

5.17.16 SET "DOV" Specific Gravity Controller to MANUAL CONTROL USING the Data Table Access Module.

5.17.17 SET the Diaphragm Operated Valve to 0\% Open USING the manual control on the Data Table Access Module. 
NOTE - DIAPHRAGM OPERATED VALVE position is read from a metal pointer mounted on the valve stem. Indication is approximate valve position only, and is NOT intended to be readable to a high degree of precision.

5.17.18RECORD the following:

\begin{tabular}{|c|c|}
\hline $\begin{array}{c}\text { DIAPHRAGM OPERATED VALVE } \\
\text { POSITION } \\
\text { ( } \% \text { OPEN) } \\
\text { [RANGE - FULLY CLOSED ( } 0-10 \% \text { on } \\
\text { needle graduations)] }\end{array}$ & $\begin{array}{l}\text { SALW-PI-6005K PRESSURE } \\
\text { (RANGE } 2 \text { to } 4 \text { psig) }\end{array}$ \\
\hline $0 \%$ & 3 psi \\
\hline
\end{tabular}

5.17.19 SET the Diaphragm Operated Valve to $25 \%$ OPEN USING the manual control on the Data Table Access Module.

5.17.20 RECORD the following:

\begin{tabular}{|c|c|}
\hline $\begin{array}{c}\text { DIAPHRAGM OPERATED VALVE } \\
\text { POSITION } \\
\text { (\% OPEN) } \\
\text { [RANGE: } 15 \% \text { to 35\%] }\end{array}$ & $\begin{array}{c}\text { SALW-PI-6005K PRESSURE } \\
\text { (RANGE: } 5 \text { to 7 psig) }\end{array}$ \\
\hline $25 \%$ & 6 ps; \\
\hline
\end{tabular}

5.17.21 SET the Diaphragm Operated Valve to $75 \%$ OPEN USING the manual control on the Data Table Access Module.

5.17.22 RECORD the following:

\begin{tabular}{|c|c|}
\hline $\begin{array}{c}\text { DIAPHRAGM OPERATED VALVE POSITION } \\
\text { (\% OPEN) } \\
\text { [RANGE: 65\% to 85\%] }\end{array}$ & $\begin{array}{c}\text { SALW-PI-6005K PRESSURE } \\
\text { (RANGE: 11 to.13 psig) }\end{array}$ \\
\hline $75 \%$ & $11.5 \mathrm{psi}$ \\
\hline
\end{tabular}


5.17.23 SET the Diaphragm Operated Valve to $100 \%$ OPEN using the manual control on the Data Table Access Module.

5.17.24 RECORD the following:

\begin{tabular}{|c|c|}
\hline $\begin{array}{c}\text { DIAPHRAGM OPERATED VALVE POSITION } \\
\text { (\% OPEN) } \\
\text { [RANGE: } 90 \% \text { to } 110 \%]\end{array}$ & $\begin{array}{c}\text { SALW-PI-6005K PRESSURE } \\
\text { RANGE: } 14 \text { to } 16 \text { psig }\end{array}$ \\
\hline $100 \%$ & $14,5 p \mathrm{si}$ \\
\hline
\end{tabular}

5.17.25 VERY SLOWLY DECREASE the test manometer pressure while OBSERVING the Diaphragm Operated Valve.

5.17.26 VERIFY that the Diaphragm Operated Valve remains FULLY OPEN while the test manometer is DECREASED until the "SGT LOW" alarm (Data Table Access Module alarm K13) annunciates.

5.17.27 VERIFY that the Diaphragm Operated Valve IMMEDIATELY CLOSES when the "SGT LOW" alarm (Data Table Access Module alarm K13) annunciates.

5.17.28 SHUT DOWN the Jet Pump with the DTAM AND ACKNOWLEDGE the shutdown alarms.

\section{OPERATOR CONTROL STATION (AUTO)}

5.17.29 ENSURE the Saltwell Pump and Jumper Assembly AND Pumping and Instrumentation Control Skid are CONFIGURED for AUTOMATIC Diaphragm Operated Valve level control by PERFORMING the following:

5.17.30 SET the test manometer to a pressure of 0" Water Gauge. 
5.17.31 ENSURE the following valves are OPEN:

\begin{tabular}{|l|c|}
\hline \multicolumn{1}{|c|}{ Valve Number } & $\checkmark$ \\
\hline SALW-V-6034K & $\swarrow$ \\
\hline SALW-V-6026K & $\swarrow$ \\
\hline SALW-V-6001K & $\swarrow$ \\
\hline SALW-V-6004K & $\swarrow$ \\
\hline SALW-V-6002K & $\checkmark$ \\
\hline
\end{tabular}

5.17.32 ENSURE the saltwell jumper JR-1 valve is in the PROCESS position.

5.17.33 At the discretion of the Engineer, ENSURE temporary interlock jumpers, OR software forces have been installed on pump permissive interlocks for equipment not installed or out of service.

$$
\text { bef } 919999
$$

5.17.34 ENSURE that only alarms "JETPUAP SHUTDOWN" and "SGT LOW" are displayed on the Operator Control Station.

5.17.35ENSURE pump recirculation apparatus is filled with water AND CONFIGURED to circulate water through the saltwell Jet Pump.

5.17.36 START the Jet Pump USING the Data Table Access Module.

5.17.37 SET the Specific Gravity Controller to AUTO with setpoint of 7.0 inches USING the Operator Control Station.

5.17.38.SET the test manometer to a pressure of 14 " Water Gauge ( $\pm 1 ")$.

5.17.39 VERIFY that the Diaphragm Operated Valve moves to a more OPEN position.

5.17.40 SET the test manometer to a pressure of 6" Water Gauge.

5.17.41 VERIFY that the Diaphragm Operated Valve moves to a more CLOSED position. 
5.17.42 VERIFY that the MANUAL CONTROL of the Diaphragm Operated Valve is operational by PERFORMING the following steps:

5.17.43 SET the test manometer to a pressure of $15^{\prime \prime}$ Water Gauge ( $\left.\pm 1 "\right)$.

5.17.44 SET the "DOV" Specific Gravity Controller to MANUAL CONTROL USING the Operator Control Station.

5.17.45 SET the Diaphragm Operated Valve to 0\% Open USING the manual control on the Operator Control Station.

5.17.46 RECORD the following:

\begin{tabular}{|c|c|}
\hline $\begin{array}{c}\text { DIAPHRAGM OPERATED VALVE POSITION } \\
\text { (\% OPEN) } \\
\text { [RANGE - FULLY CLOSED (0-10\% OPEN)] }\end{array}$ & $\begin{array}{c}\text { SALW-PI-6005K PRESSURE } \\
\text { (RANGE 2 to 4 psig) }\end{array}$ \\
\hline $0 \%$ & $3.5 \mathrm{ps} ;$ \\
\hline
\end{tabular}

5.17.47 SET the Diaphragm Operated Valve to $25 \%$ OPEN using the manual control on the Operator Control Station.

$$
\begin{aligned}
& 30 \% \text { B (u1) } \\
& 9 / 16 / 99
\end{aligned}
$$

5.17.48RECORD the following:

\begin{tabular}{|c|c|}
\hline $\begin{array}{c}\text { DIAPHRAGM OPERATED VALVE POSITION } \\
\text { (\% OPEN) } \\
\text { [RANGE: } 15 \% \text { to 35\%] }\end{array}$ & $\begin{array}{c}\text { SALW-PI-6005K PRESSURE } \\
\text { (RANGE: } 5 \text { to 7. psig) }\end{array}$ \\
\hline $25 \%$ & 7 ps \\
\hline
\end{tabular}

5.17.49 SET the Diaphragm Operated Valve to $75 \%$ OPEN using the manual control on the Operator Control Station. $80 \%$

$$
\text { BG) } 910199
$$


5.17.50RECORD the following:

\begin{tabular}{|c|c|}
\hline $\begin{array}{c}\text { DIAPHRAGM OPERATED VALVE POSITION } \\
\text { (\% OPEN) } \\
\text { [RANGE: 65\% to 85\%] }\end{array}$ & $\begin{array}{c}\text { SALW-PI-6005K PRESSURE } \\
\text { (RANGE: } 11 \text { to 13 psig) }\end{array}$ \\
\hline $75 \%$ & $12.75 \mathrm{psi}^{\mathrm{s}}$ \\
\hline
\end{tabular}

5.17.51 SET the Diaphragm Operated Valve to $100 \%$ OPEN using the manual control on the Operator Control Station.

5.17.52 RECORD the following:

\begin{tabular}{|c|c|}
\hline $\begin{array}{c}\text { DIAPHRAGM OPERATED VALVE POSITION } \\
\text { (\% OPEN) } \\
\text { [RANGE: } 90 \% \text { to 110\%] }\end{array}$ & $\begin{array}{c}\text { SALW-PI-6005K PRESSURE } \\
\text { RANGE: } 14 \text { to } 16 \text { psig }\end{array}$ \\
\hline $100 \%$ & $15 \mathrm{ps} i$ \\
\hline
\end{tabular}

5.17.53 VERY SLOWLY DECREASE the test manometer pressure while OBSERVING the Diaphragm Operated Valve.

5.17.54 VERIFY that the Diaphragm Operated Valve remains FULLY OPEN while the test manometer is DECREASED UNTIL the Operator Control Station "SGT LOW" annunciates.

5.17.55 VERIFY that the Diaphragm Operated Valve IMMEDIATELY CLOSES when the Operator Control Station "SGT LOW" annunciates.

5.17.56 SHUTDOWN the Jet Pump with the Operator Control Station.

5.17.57 VERIFY the Jet Pump SHUT DOWN at the Operator Control Station. 


\section{HNF -4277 \\ REVISION 0}

5.17.58 REMOVE any jumpers or forces NOT required for the next test section.

5.17.59 Engineer VERIFY that section 5.17 is complete by SIGNING below.

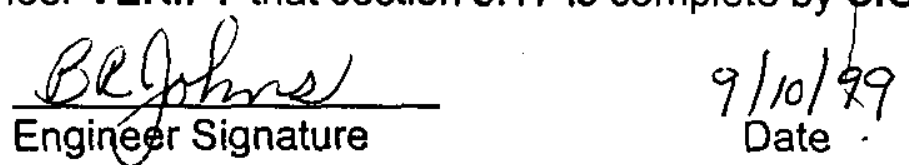

5.17.60 Quality Assurance Inspector VERIFY that section 5.17 is complete by signing below.

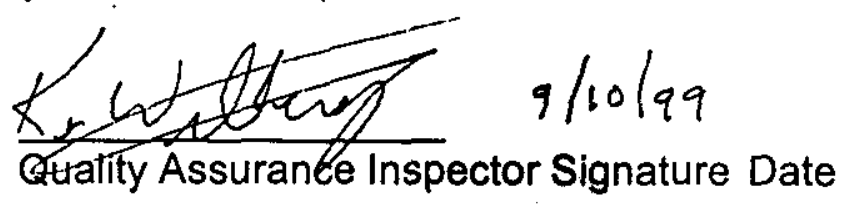


REVISION 0

\subsection{JET PUMP FLOWMETER OPERATION}

NOTE: The CGI dedication will be performed for the flow meter and flow head during this section of the ATP. Completion of this section will verify flow meter accuracy as required for CGI dedication. QC Hold point on $J>$ signed and verified

5.18.1 ENSURE that the Saltwell Jumper Flow Element is communicating properly with the FQIT SALW-FQIT-6001K (SUPERNATANT FLOW XMIT) and Data Table Access Module by PERFORMING the following:

5.18.2 PLACE the saltwell jumper JR-1 valve in the PROCESS position.

5.18.3 ENSURE Pump recirculation apparatus is filled with water AND configured to circulate water through the saltwell Jet Pump.

5.18.4 ENSURE the 0 - 50 inch test manometer is still attached to the high pressure dip . tube AND set to $15^{\prime \prime}$ Water Gauge ( $\left.\pm 1 "\right)$.

5.18.5 ENSURE a rotameter has been installed in series with the jumper flow element.
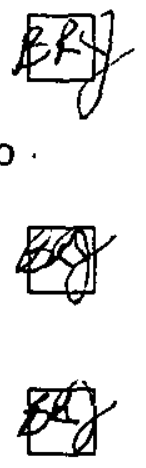

5.18.6 ENSURE that both the Data Table Access Module and Operator Control Station are configured for MANUAL CONTROL.

5.18.7 At the discretion of the Engineer, ENSURE temporary interlock jumpers, OR software forces are in place for uninstalled equipment.
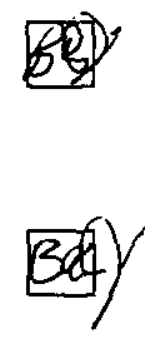

5.18.8 SET the Diaphragm Operated Valve to 0\% OPEN using the manual control on the Data Table Access Module.

5.18.9 ADJUST Jet Pump Jumper Valve JR-2 as directed by the Engineer to achieve the required flow rates in the following steps.

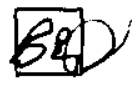

5.18.10 START the Jet Pump using the Data Table Access Module.

5.18.11 VERIFY the start of the Jet Pump at the Operator Control Station. 
5.18.12 RECORD initial readings, and the time reading were taken.

\begin{tabular}{|c|c|c|}
\hline $\begin{array}{c}\text { DATA TABLE ACCESS } \\
\text { MODULE TOTALIZER (Gallons) }\end{array}$ & $\begin{array}{l}\text { FQIT TOTALIZER } \\
\text { GALLONS }\end{array}$ & TIME \\
\hline 1.73 & 1.73 & $2: 36 \mathrm{Pm}$ \\
\hline
\end{tabular}

5.18.13 SET the Draphragm Operated Valve Controllet to MANUAL AND ADJUST Controller at the Data Table Access Module to obtain a flowrate of APPROXIMATELY 1.0 GPM $( \pm 0.05 \mathrm{gpm})$ through the jumper.

5.18.14 RECORD the following:

\begin{tabular}{|c|c|c|c|c|c|c|c|c|}
\hline $\begin{array}{c}\text { DTAM } \\
\text { MANUAL } \\
\text { CONTROL } \\
\text { DOV } \\
\text { POSITION (\%) }\end{array}$ & $\begin{array}{c}\text { OCS } \\
\text { MANUAL } \\
\text { CONTROL } \\
\text { DOV } \\
\text { POSITION } \\
(\%)\end{array}$ & $\begin{array}{c}\text { DOV } \\
\text { POSITIO } \\
N \\
\text { (\% } \\
\text { OPEN) }\end{array}$ & $\begin{array}{c}\text { TEST } \\
\text { ROTAMETE } \\
R \\
\text { FLOWRATE } \\
\text { (GPM) }\end{array}$ & $\begin{array}{l}\text { (INSTR) } \\
\text { FQIT } \\
\text { FLOWRA } \\
\text { TE (GPM) }\end{array}$ & $\begin{array}{l}\text { DTAM } \\
\text { FLOWRA } \\
\text { TE (GPM) }\end{array}$ & $\begin{array}{l}\text { OCS } \\
\text { FLOWRA } \\
\text { TE (GPM) }\end{array}$ & $\begin{array}{c}\text { DTAM } \\
\text { TOTALLIZR } \\
\text { (GALLONS) }\end{array}$ & $\begin{array}{c}\text { FQIT } \\
\text { TOTALLZER } \\
\text { (GALLONS) }\end{array}$ \\
\hline 45 & 45 & 35 & 1.2 & 1.14 & 1.145 & & 7785 & 297 \\
\hline
\end{tabular}

5.18.15 VERIFY that Test Rotameter flowrate, FQIT SALW-FQIT-6001K flowrate, Data Table Access Module flowrate, AND Operator Control Station flowrate are within $\pm 0.1 \mathrm{gpm}$.
$\frac{\text { BRhone }}{\text { Engineer Signature }}$
$9 / 10 / 99$

5.18.16 SUBTRACT totalizer INITIAL reading for Data Table Access Module from the current totalizer reading for Data Table Access Module.

RECORD result: 5 gallons

5.18.17 SUBTRACT INITIAL totalizer reading for FQIT from the current totalizer reading for the FQIT.

$$
\text { RECORD result: } 4 \text { gallons }
$$

5.18.18 VERIFY results from the above two steps are within \pm 5.0 gallons. 
HNF -4277

REVISION 0

5.18.19 ADJUST the Diaphragm Operated Valve Controller to obtain a flowrate of APPROXIMATELY $2.5 \mathrm{GPM}( \pm 0.125 \mathrm{gpm})$ through the jumper.

5.18.20 RECORD the following:

\begin{tabular}{|c|c|c|c|c|c|c|c|c|}
\hline $\begin{array}{c}\text { DTAM } \\
\text { MANUAL } \\
\text { CONTROL } \\
\text { DOV } \\
\text { POSITION (\%) }\end{array}$ & $\begin{array}{c}\text { OCS } \\
\text { MANUAL } \\
\text { CONTROL } \\
\text { DOV } \\
\text { POSITION } \\
(\%)\end{array}$ & $\begin{array}{c}\text { DOV } \\
\text { POSITIO } \\
N \\
(\% \\
\text { OPEN) }\end{array}$ & $\begin{array}{c}\text { TEST } \\
\text { ROTAMETE } \\
\mathbf{R} \\
\text { FLOWRATE } \\
\text { (GPM) }\end{array}$ & $\begin{array}{c}\text { (INSTR) } \\
\text { FQIT } \\
\text { FoWWRA } \\
\text { TE (GPM) }\end{array}$ & $\begin{array}{c}\text { DTAM } \\
\text { FLOWRA } \\
\text { TE (GPM) }\end{array}$ & $\begin{array}{c}\text { OCS } \\
\text { FLOWRA } \\
\text { TE (GPM) }\end{array}$ & $\begin{array}{c}\text { DTAM } \\
\text { TOTALIZER } \\
\text { (GALLONS) }\end{array}$ & $\begin{array}{c}\text { FQIT } \\
\text { TOTALIZER } \\
\text { (GALLONS) }\end{array}$ \\
\hline 85 & 85 & 50 & 2.65 & 668 & 2,70 & 2.698 & 7802 & 315 \\
\hline
\end{tabular}

5.18.21 VERIFY that Test Rotameter flowrate, FQIT SALW-FQIT-6001K flowrate, Data Table Access Module flowrate, AND Operator Control Station flowrate are within $\pm 0.25 \mathrm{gpm}$.

5.18.22 SUBTRACT totalizer INITIAL reading for Data Table Access Module from the current totalizer reading for Data Table Access Module.

RECORD result: 14 gallons

5.18.23 SUBTRACT INITIAL totalizer reading for FQIT from the current totalizer reading for the FQIT.

RECORD result: 14 gallons

5.18.24 VERIFY results from the above two steps are within \pm 5.0 gallons.

5.18.25 ADJUST the Diaphragm Operated Valve Controller to obtain a flowrate of

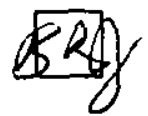

5.18 .24 VERIFY results from the above two steps are within +5.0 gallons.

APPROXIMATELY $3.0 \mathrm{GPM}( \pm 0.15 \mathrm{gpm})$ through the jumper. 
5.18.26 RECORD the following:

\begin{tabular}{|c|c|c|c|c|c|c|c|c|}
\hline $\begin{array}{c}\text { DTAM } \\
\text { MANUAL } \\
\text { CONTROL } \\
\text { DOV } \\
\text { POSITION (\%) }\end{array}$ & $\begin{array}{c}\text { OCS } \\
\text { MANUAL } \\
\text { CONTROL } \\
\text { DOV } \\
\text { POSITION } \\
(\%)\end{array}$ & $\begin{array}{c}\text { DOV } \\
\text { POSITIO } \\
N \\
\text { (\% } \\
\text { OPEN) }\end{array}$ & $\begin{array}{c}\text { TEST } \\
\text { ROTAMETE } \\
\text { R } \\
\text { FLOWRATE } \\
\text { (GPM) }\end{array}$ & $\begin{array}{l}\text { (INSTR) } \\
\text { FQIT } \\
\text { FLOWRA } \\
\text { TE (GPM) }\end{array}$ & $\begin{array}{l}\text { DTAM } \\
\text { FLOWRA } \\
\text { TE (GPM) }\end{array}$ & $\begin{array}{c}\text { OCS } \\
\text { FLOWRA } \\
\text { TE (GPM) }\end{array}$ & $\begin{array}{l}\text { DTAM } \\
\text { TOTALIZER } \\
\text { (GALLONS) }\end{array}$ & $\begin{array}{c}\text { FaIT } \\
\text { TOTALIZER } \\
\text { (GALLONS) }\end{array}$ \\
\hline 85 & 8 & 50 & 3.15 & 3.20 & 3.21 & 3.20 & 7810 & 323 \\
\hline
\end{tabular}

5.18.27 VERIFY that Test Rotameter flowrate, FQIT SALW-FQIT-6001K flowrate, Data Table Access Module flowrate, AND Operator Control Station flowrate are within $\pm 0.3 \mathrm{gpm}$.
$\frac{B \times 2 \text { ons }}{\text { Engineersignature }}$
$9 / 10 / 99$

5.18.28 SUBTRACT totalizer INITIAL reading for Data Table Access Module from the current totalizer reading for Data Table Access Module.

RECORD result: 22 gallons

5.18.29 SUBTRACT INITIAL totalizer reading for FQIT from the current totalizer reading for the FQIT.

RECORD result: 22 gallons

5.18.30 VERIFY results from the above two steps are within \pm 5.0 gallons.

5.18.31 CLOSE the Diaphragm Operated Valve (to $0 \%$ ) using the manual Diaphragm

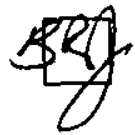
Operated Valve control.

5.18.32 VERIFY JR-2 is CLOSED.

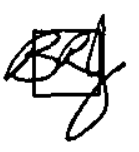


5.18.33RECORD the following:

\begin{tabular}{|c|c|c|c|c|c|c|c|c|}
\hline $\begin{array}{c}\text { DTAM } \\
\text { MANUAL } \\
\text { CONTROL } \\
\text { DOV } \\
\text { POSITION (\%) }\end{array}$ & $\begin{array}{c}\text { OCS } \\
\text { MANUAL } \\
\text { CONTROL } \\
\text { DOV } \\
\text { POSITION } \\
(\%)\end{array}$ & $\begin{array}{c}\text { DOV } \\
\text { POSITIO } \\
\text { N } \\
(\% \\
\text { OPEN) }\end{array}$ & $\begin{array}{c}\text { TEST } \\
\text { ROTAMETE } \\
\text { R } \\
\text { FLOWRATE } \\
\text { (GPM) }\end{array}$ & $\begin{array}{c}\text { (INSTR) } \\
\text { FQIT } \\
\text { FLOWRA } \\
\text { TE (GPM) }\end{array}$ & $\begin{array}{c}\text { DTAM } \\
\text { FLOWRA } \\
\text { TE (GPM) }\end{array}$ & $\begin{array}{c}\text { OCS } \\
\text { FLOWRA } \\
\text { TE (GPM) }\end{array}$ & $\begin{array}{c}\text { DTAM } \\
\text { TOTALIZER } \\
\text { (GALLONS) }\end{array}$ & $\begin{array}{c}\text { FQIT } \\
\text { TOTALIZER } \\
\text { (GALLONS) }\end{array}$ \\
\hline 0 & 0 & 0 & 0 & 0 & 0 & 0 & 7817 & 330 \\
\hline
\end{tabular}

5.18.34 VERIFY that Test Rotameter flowrate, FQIT SALW-FQIT-6001K flowrate, Data Table Access Module flowrate, AND Operator Control Station flowrate all indicate $0.0 \mathrm{gpm}$ $( \pm 0.1 \mathrm{gpm})$.

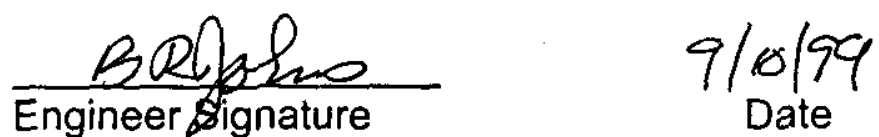

5.18.35 SUBTRACT totalizer INITIAL reading for Data Table Access Module from the current totalizer reading for Data Table Access Module.

RECORD result: 29 gallons

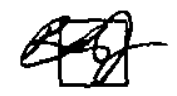

5.18.36 SUBTRACT INITIAL totalizer reading for FQIT from the current totalizer reading for the FQIT.

RECORD result: 29 gallons

5.18.37 VERIFY results from the above two steps are within \pm 5.0 gallons.

5.18.38 USING the Data Table Access Module, STOP the Jet Pump.

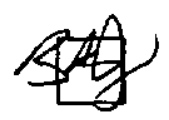

5.18.39 REMOVE the test manometer.

5.18.40 ISOLATE the Specific Gravity Transmitter from the system.

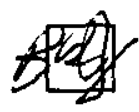

NOTE - All three valves are located on the Specific Gravity Transmitter three valve manifold SALW-V-6035K.

5.18.41 OPEN the equalization valve for the Specific Gravity Transmitter.

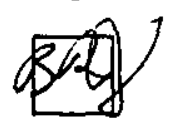


5.18.42 CLOSE the two (2) isolation valves.

5.18.43 REMOVE any jumpers or forces NOT required for the next test section.

5.18.44 Engineer VERIFY that section 5.18 is complete by SIGNING below.

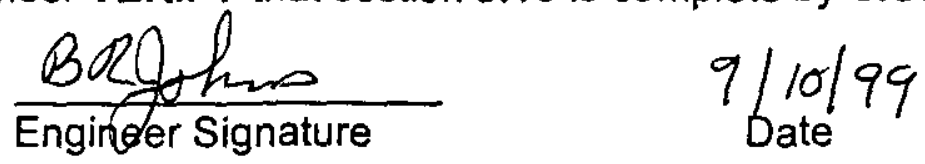

5.18.45 Quality Assurance Inspector VERIFY that section 5.18 is complete by signing below.

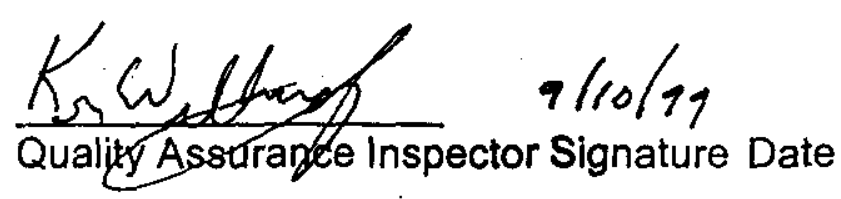


HNF -4277

REVISION 0

\subsection{JET PUMP VALVING INTERLOCK FOR THE JET PUMP}

5.19.1 ENSURE Pump recirculation apparatus is filled with water AND configured to circulate water through the saltwell Jet Pump.

5.19.2 ENSURE all alarms have been acknowledged at the Data Table Access Module and Operator Control Station.

5.19.3 At the discretion of the Engineer, ENSURE temporary interlock jumpers, OR software forces have been installed on pump permissive interlocks for equipment not installed or out of service.

5.19.4 USING the Data Table Access Module, START the Jet Pump.

5.19.5 VERIFY Jet Pump operation at the Operator Control Station.

5.19.6 PLACE the JR-1 Valve, on the Jet Pump jumper, in the FLUSH position.

5.19.7 VERIFY the following:

- Jet Pump IMMEDIATELY shuts down.

- $\quad$ "JR-1 NON-PROCESS" is displayed at Data Table Access Module AND BRO "FLUSH" a/4/99

- $\quad$ "Jet Pump SHUTDOWN" is displayed at Data Table Access Module and Operator Control Station.

NOTE - $\quad$ "Flush Pressure HI" may be received.

5.19.8 VERIFY the Jet Pump can not be re-started with the JR-1 valve in the FLUSH position. 
HNF-4277

REVISION 0

5.19.9 PLACE the JR-1 Valve in the PROCESS position.

5.19.10 ENSURE all alarms have been acknowledged at the Data Table Access Module and Operator Control Station.

5.19.11 RESTART the Jet Pump using the Data Table Access Module.

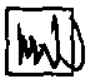

5.19.12 VERIFY Jet Pump operation at the Operator Control Station.

5.19.13 PLACE the JR-1 Valve in the PRIME position.

5.19.14 VERIFY the following:

- Jet Pump IMMEDIATELY shuts down.

- J. J PUTP IMMEDIATELY shuts down.

- $\quad$ "JR-1 NON-PROCESS" is displayed at Data Table Access Module AND Operator Control Station (ALARMK5)

$$
\text { *5. } 970199
$$

- $\quad$ "Jet Pump SHUTDOWN" is displayed at Data Table Access Module and Operator Control Station (ALARMNK12).

* Be $q(10)^{49}$ prict to per forming. 5. 19.15. BRe 2/10/99

5.19.15 VERIFY the Jet Pump can not be re-started with the JR-1 valve in the PRIME position.

5.19.16ENSURE all alarms have been acknowledged at the Data Table Access Module and Operator Control Station.

5.19.17 REMOVE any jumpers or forces NOT required for the next test section. 
NF -4277

REVISION 0

5.19.18 Engineer VERIFY that section 5.19 is complete by SIGNING below.

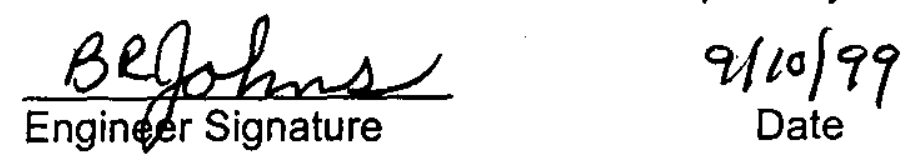

5.19.19 Quality Assurance Inspector VERIFY that section 5.19 is complete by signing below.

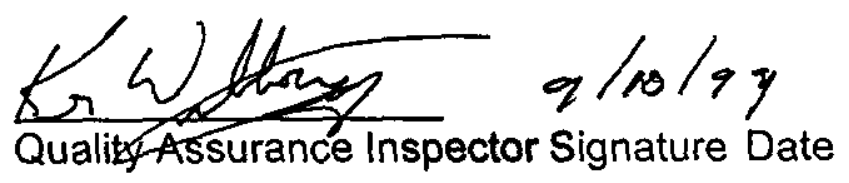

PAGE A78 
HNF-4277

REVISION 0

\subsection{OPERATOR CONTROL STATION JET PUMP SHUTDOWN TEST}

5.20.1 PLACE the Jet Pump JR-1 valve in the PROCESS position.

5.20.2 ENSURE Pump recirculation apparatus is filled with water AND configured to circulate water through the saltwell Jet Pump.

5.20.3 ENSURE no interlocks are present that will prevent pump operation.

- At the discretion of the Engineer, jumper or force interlocks if necessary.

5.20.4 Using the Data Table Access Module, START the Jet Pump.

5.20.5 VERIFY Jet Pump operation at the Operator Control Station.

5.20.6 Using the Operator Control Station, SHUT DOWN the Jet Pump.

5.20.7 VERIFY the JETPUAP-SHUTDOWN alarm at the Operator Control Station.

$$
\text { Bey } 911199
$$

5.20.8 Engineer VERIFY that section 5.20 is complete by SIGNING below.

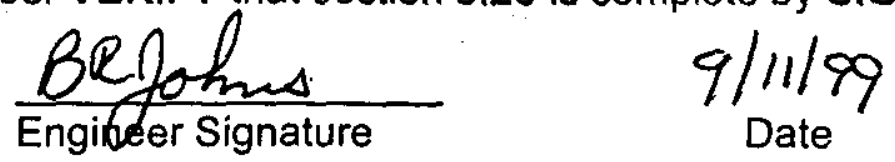

5.20.9 Quality Assyrance Inspector VERIFY that section 5.20 is complete by signing below.

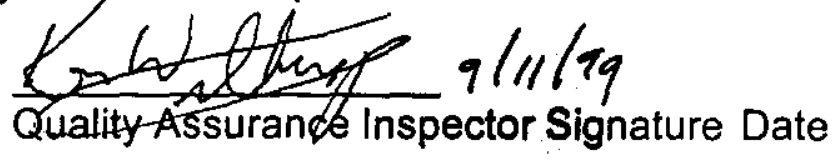


HNF-4277

REVISION 0

\subsection{LEAK DETECTION INTERLOCK CHECK}

NOTE: Perform section 5.11 simultaneously with this section. N/A step 5.11 .2 since the CGI's are completed.

5.21.1 Set up two buckets for leak detector testing.

NOTE - A supply of water needs to be available to pour into the buckets during testing.

- Pump operation will be simulated during the remainder of the ATP.

- There are two leak detection circuits on the skid. Each circuit will be tested separately as the primary and leak detector 1 .

5.21.2 IF REQUIRED, ENSURE the Pump Instrument and Control Skid is configured and ready to receive leak detector signal.

5.21.3 MONITOR the status of the Pump Starter to VERIFY pump status.

5.21.4 ENSURE no interlocks are present that will prevent pump operation.
- At the discretion of the Engineer, force or jumper unused interlocks. interlocks.

5.21.5 Using Data Table Access Module, START the Jet Pump.

NOTE - Programmer may need to force limit switches and pressure switches to simulate recirculate flow. 
HNF-4277

REVISION 0

\section{WARNING}

Energized circuits and leads are contained inside the cabinet. Observe appropriate electrical. Comply with WHC-CM-1-10, WKS-15, ELECTRICAL WORK SAFETY to avoid personnel electrical shock hazards.

\section{PRIMARY LEAK DETECTOR:}

5.21.6 TEST leak detector by emerging probe, as required. VERIFY and ACKNOWLEDGE the following:

- IMMEDIATE Jet Pump shutdown.

- $\quad$ "JET PUMP SHUTDOWN" is annunciating at the Data Table Access Module (ALARM \#12).

- A Leak Detection Alarm is annunciating at the Data Table Access Module.

5.21.7 ACKNOWLEDGE the Leak Detector Alarm at the Data Table Access Module and OCS.

5.21.8 VERIFY that the Jet Pump CAN NOT be re-started at the Data Table Access Module when the alarm is ACTIVE.

5.21.9 RETURN the leak detector to a condition of operation by PERFORMING the following:

- REMOVE the probe from the bucket.

- VERIFY the Leak Detection Alarm at the Data Table Access Module and OCS resets. 
LEAK DETECTOR $2 / 1$ B $2 X$

Repeat step 15.21 .2 to 5.21 .5 beg

5.21.10 TEST leak detector by emerging probe, as required. VERIFY and ACKNOWLEDGE the following:

- IMMEDIATE Jet Pump shutdown.

- $\quad$ "JET PUMP SHUTDOWN" is annunciating at the Data Table Access Module (ALARM \#12).

- A Leak Detection Alarm is annunciating at the Data Table Access Module.

5.21.11 ACKNOWLEDGE the Leak Detector Alarm at the Data Table Access Module and OCS.

5.21.12 VERIFY that the Jet Pump CAN NOT be re-started at the Data Table Access Module when the alarm is ACTIVE.

5.21.13 RETURN the leak detector to a condition of operation by PERFORMING the following:

- REMOVE the probe from the bucket.

- VERIFY the Leak Detection Alarm at the Data Table Access Module and OCS resets. 
NOTE - It is the intent of this section to test all transfer system and FGM interlocks not previously tested in the leak detector section. Included would be dilution tank low level alarms and FGM alarms not previously tested.

5.21.14 The table below identifies the interlocks to be tested.

\begin{tabular}{|c|c|c|}
\hline $\begin{array}{l}\text { RELAY/DEVICE } \\
\text { DESIGNATION }\end{array}$ & $\begin{array}{l}\text { JET PUMP } \\
\text { SHUTDOWN } \\
(\checkmark)\end{array}$ & ALARM MESSAGE RECEIVED \\
\hline \multirow[t]{2}{*}{ 1) FGM interlock } & 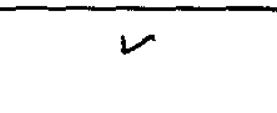 & $\begin{array}{l}\text { DTAM Al arm } 12 \text { Jet Puimp Shutbown } \\
\text { Alaxh } 22 \text { Flammble Gas hijh }\end{array}$ \\
\hline & r & ocs FGem Hi, Jetting, Shutdoum \\
\hline \multirow[t]{2}{*}{ 2) Dilution tank low level } & \multirow[t]{2}{*}{ レ } & 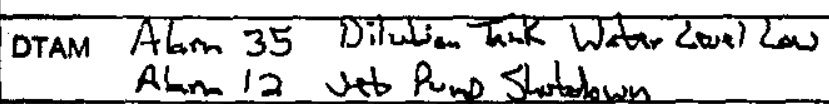 \\
\hline & & $\begin{array}{l}\text { ocs Dilut Lul Las } \\
\text { Shutdown }\end{array}$ \\
\hline
\end{tabular}

\section{WARNING}

Energized circuits and leads are contained inside the cabinet. Observe appropriate electrical. Comply with WHC-CM-1-10, WKS-15, ELECTRICAL WORK SAFETY to avoid personnel electrical shock hazards.

5.21.15 For each relay listed in the Table above, PERFORM the following:

5.21.16 Using the Data Table Access Module, START the Jet Pump, AND OBSERVE that the pump run light is $O N$.

5.21.17 DEACTIVATE the relay to simulate an alarm condition.

NOTE - Craft will determine a safe method of deactivating each device. Test pushbuttons, mock input signals, shorting across secondary of induction relay coils, lifting coil leads, or pulling device from socket may be used.

5.21.24 VERIFY Data Table Access Module and Operator Control Station display "JET PUMP SHUTDOWN" AND an interlock message. 


\section{HNF -4277}

\section{REVISION 0}

5.21.25RECORD a check mark in the Table if Jet Pump shutdown occurs.

5.21.26 RECORD the interlock alarm messages received at Data Table Access Module and Operator Control Station in the Table.

5.21.27 VERIFY that the Jet Pump CAN NOT be re-started at the Data Table Access Module when the alarm is ACTIVE.

5.21.28RESTORE the circuit (remove simulated alarm condition).

5.21.29 ACKNOWLEDGE the alarms at Data Table Access Module and Operator Control Station.

5.21.30 REMOVE any jumpers or forces.

Hull

5.21.31 ATTACH a copy of the PLC and DTAM programs to this ATP.

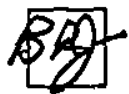

5.21.32 SECURE the skid per sections 4.4.2.7, 4.4.2.8 and 4.4.2.9 for moving the skid to the field.

5.21.33 Engineer VERIFY that section 5.21 is complete by SIGNING below.

$$
\frac{1 \text { halnich }}{\text { Engineer Signature }} \quad \begin{gathered}
9-11-94 \\
\text { Date }
\end{gathered}
$$

5.21.33 Quality Assurance Inspector VERIFY that section 5.21 is complete by signing below.

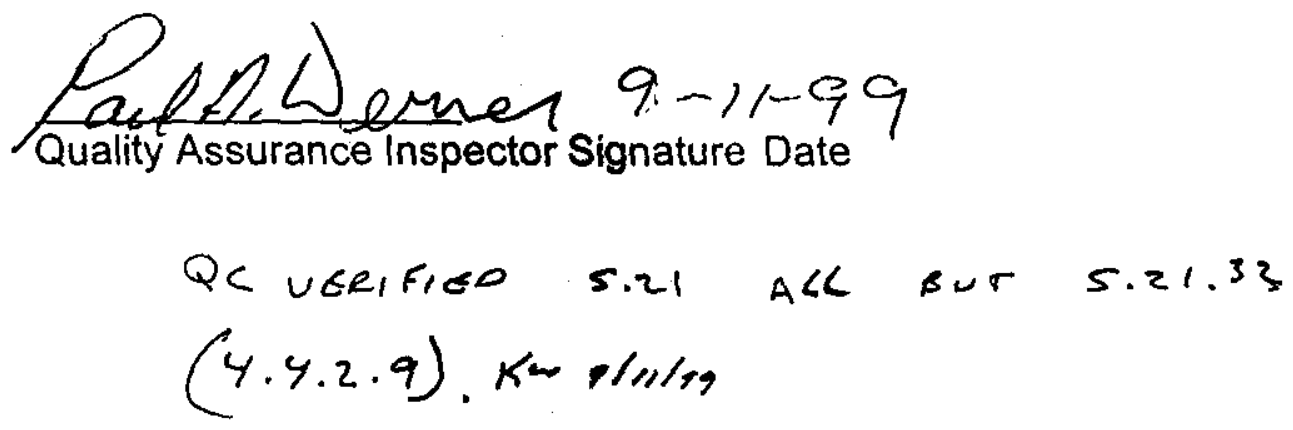



of

\section{ACCEPTANCE TEST PROCEDURE LOG}

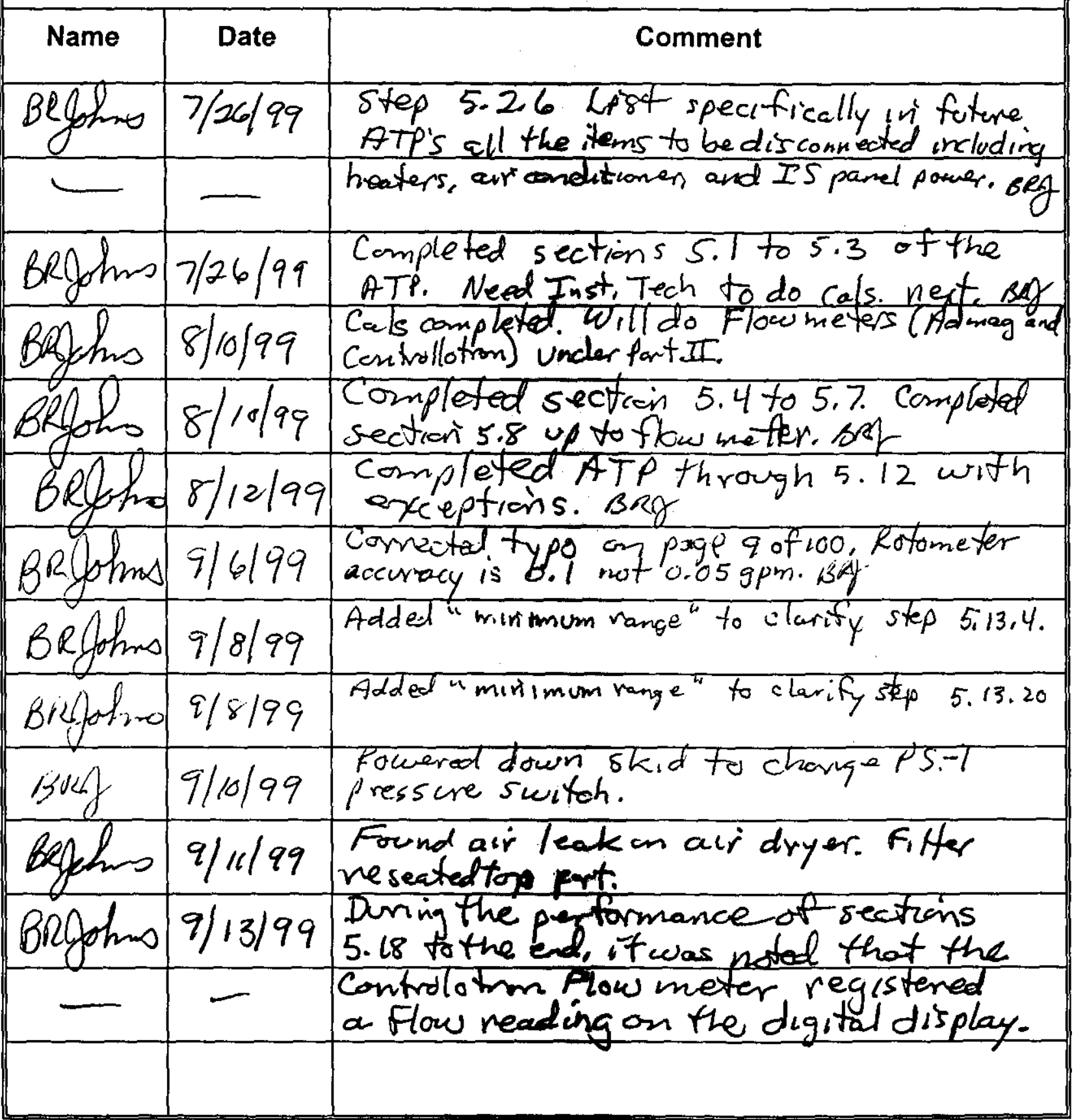

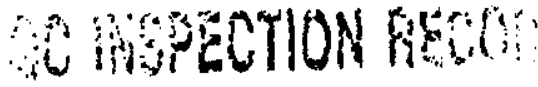




\section{ACCEPTANCE TEST PROCEDURE EXCEPTION LOG}

This page may be reproduced as necessary

PAGE 1 of 3

\section{ACCEPTANCE TEST PROCEDURE EXCEPTION LOG}

\begin{tabular}{|c|c|c|}
\hline Number & Date & Description \\
\hline & $7 / 21 / 99$ & $\begin{array}{l}\text { Section } 4.1 \text { Drug. Verification } \\
H-14-103530 \text { sht } 7 \text { : Draftin to fix uring labol }\end{array}$ \\
\hline & & 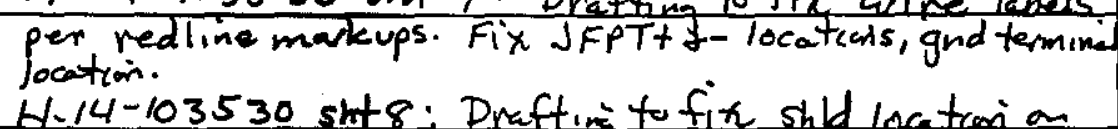 \\
\hline & & 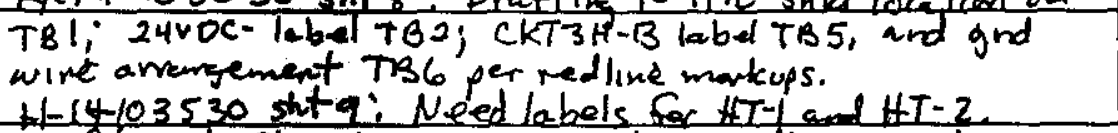 \\
\hline & & $\begin{array}{l}\text { Dreffing to fix HT- } 3 \text { wire lo bel per redline morkep. } \\
1,14-103530,5 \text { ht } 11 \text {. Drafting to fix wive vun to ind icators; }\end{array}$ \\
\hline & & 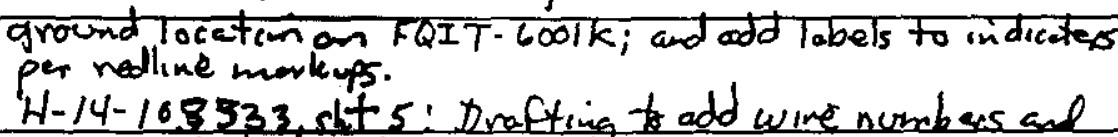 \\
\hline & & 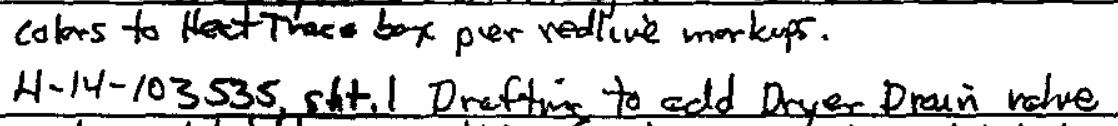 \\
\hline & & 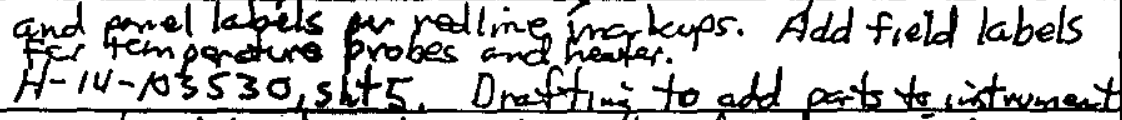 \\
\hline & & $\begin{array}{l}\text { pand and lovel in strumest panol and esater abinat per } \\
\text { redline mork ups. BRSohms } 7 / 21 / 99\end{array}$ \\
\hline & $6 / 99$ & $\begin{array}{l}\text { Step } 4.4,2.8 \text { Added valve SALW-V-6043K } \\
\text { which was anitted from the valve list. }\end{array}$ \\
\hline & 6199 & $\begin{array}{l}\text { Step } 5.1 .5 \text { Contingity was measured } \\
\text { at load side of transformer through primary }\end{array}$ \\
\hline & & was, \\
\hline & $7 / 26 / 99$ & $\begin{array}{l}\text { Step } 5.196 \text { Cgntiniuly was measured } \\
\text { at panel boand through secoudary coll of }\end{array}$ \\
\hline & & $\begin{array}{l}\text { Thanstermer sinice access to secondany } \\
\text { wires was not practical. Neatral wes }\end{array}$ \\
\hline & & $\begin{array}{l}\text { I. fled to verity no short to } g \text { round bf the } \\
\text { two hot wires and neatral wire. }\end{array}$ \\
\hline
\end{tabular}




\section{ACCEPTANCE TEST PROCEDURE EXCEPTION LOG}

This page may be reproduced as necessary

PAGE 2 of 3

\section{ACCEPTANCE TEST PROCEDURE EXCEPTION LOG}

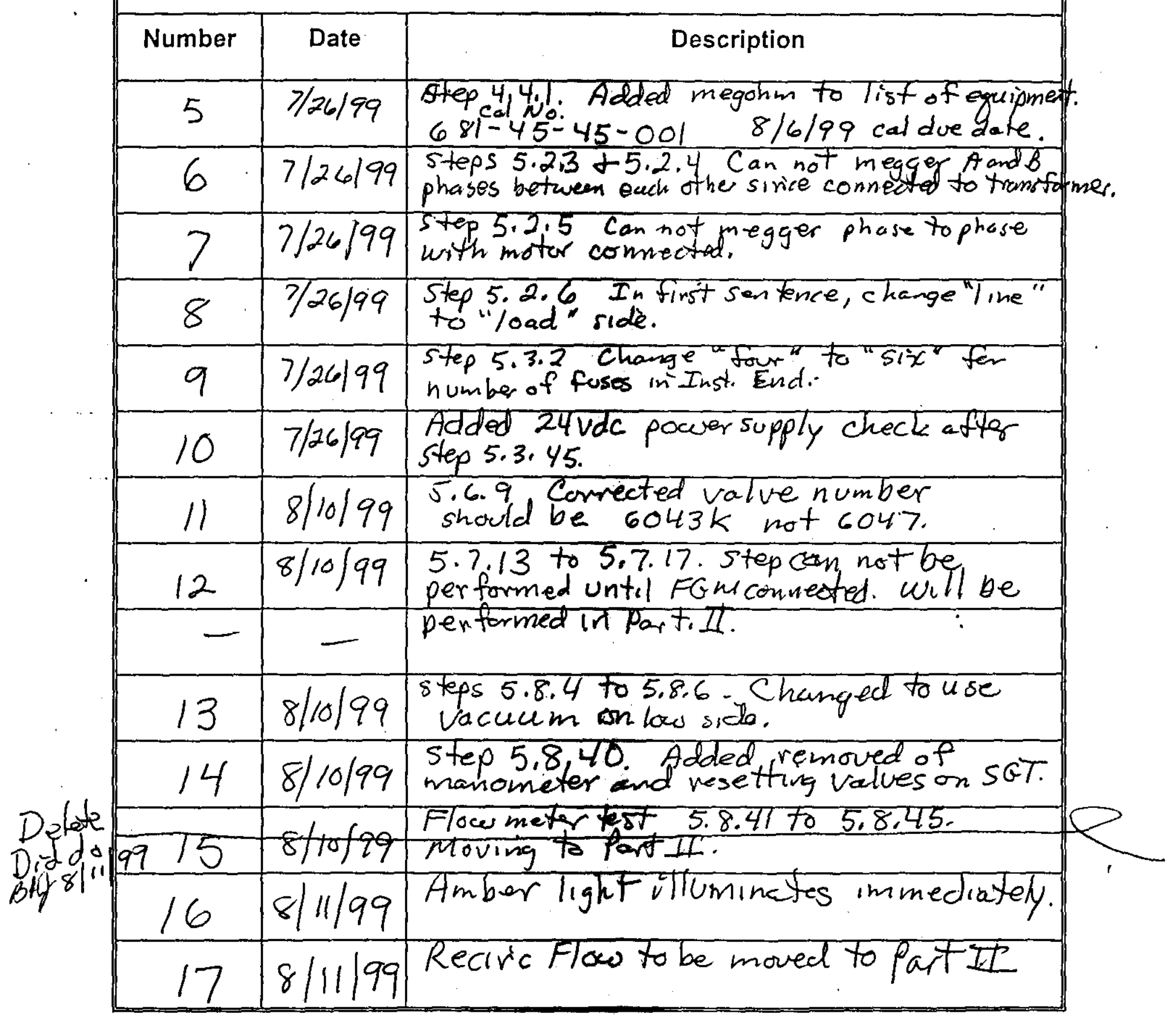

OC IMSPECTION BECORD 


\section{ACCEPTANCE TEST PROCEDURE EXCEPTION LOG}

This page may be reproduced as necessary

PAGE 3 of 3

\section{ACCEPTANCE TEST PROCEDURE EXCEPTION LOG}

\begin{tabular}{|c|c|c|}
\hline Number & Date & Description \\
\hline+8 & $8 / 11 / 99$ & steps 5.9.1 fo 5.9.7 switch positions \\
\hline 70 & & worked opposite as listod. \\
\hline 19 & $8 / 12199$ & $\begin{array}{l}\text { Section 5.ll not pertarmed. Move to } \\
\text { part If. }\end{array}$ \\
\hline 20 & $8 / 12 / 99$ & $\begin{array}{l}\text { step 5.12.70. Added instructions to } \\
\text { bleed off air pressure. }\end{array}$ \\
\hline 21 & $8 / 30 / 99$ & $\begin{array}{l}\text { Step4.4.2.3. Add drawing to H-14-. } \\
100542 \text { shty and any EcN/s. and drawing }\end{array}$ \\
\hline & & H-14-103530 shifs 7 and $8,9,11$ and 13 . \\
\hline 22 & $9 / 6 / 99$ & 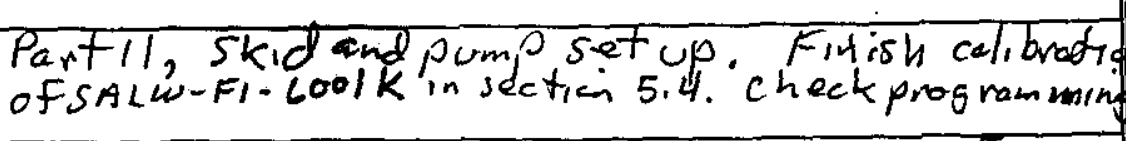 \\
\hline- & -1 & $\begin{array}{l}\text { in'sectiori } 5.5 \text {. Performing sectici' } 5.6 .1 \text { to } 5.6 .6 \\
\text { and } 5.6 .11 \text { to } 5.6 .40 \text {. }\end{array}$ \\
\hline 23 & $9 / 8 / 99$ & step 5.13 .34$. PS-1 Switeh faited: \\
\hline 24 & $9 / 8 \longdiv { 9 9 }$ & Step 5.14.51 Nued atarm ack Step.: \\
\hline 25 & $9 / 9199$ & $\begin{array}{l}\text { Step 5.15.10 SALW-V-6005K goes to } \\
\text { zero atter alarm occurs. }\end{array}$ \\
\hline 26 & $9 / 9 / 99$ & $\begin{array}{l}\text { Step } 5.16 .1 \text { Remove wianometer from } \\
\text { SGT. }\end{array}$ \\
\hline 27 & $9 / 10 / 99$ & $\begin{array}{l}5 \text { tep } 5.14 .41 \text { Noed to ack alarris. } \\
\text { Delexe stee } 5.14 .43 .\end{array}$ \\
\hline 28 & $9 / 11 / 99$ & $\begin{array}{l}\text { Steps } 5.11 .13,5.11 .24,5.11 .25 \text { need to } \\
\text { Verity troulle alarm clears. }\end{array}$ \\
\hline
\end{tabular}

QC MSPFCTION RECORD 


\section{ACCEPTANCE TEST PROCEDURE EXCEPTION RECORD}

This page may be reproduced as necessary.

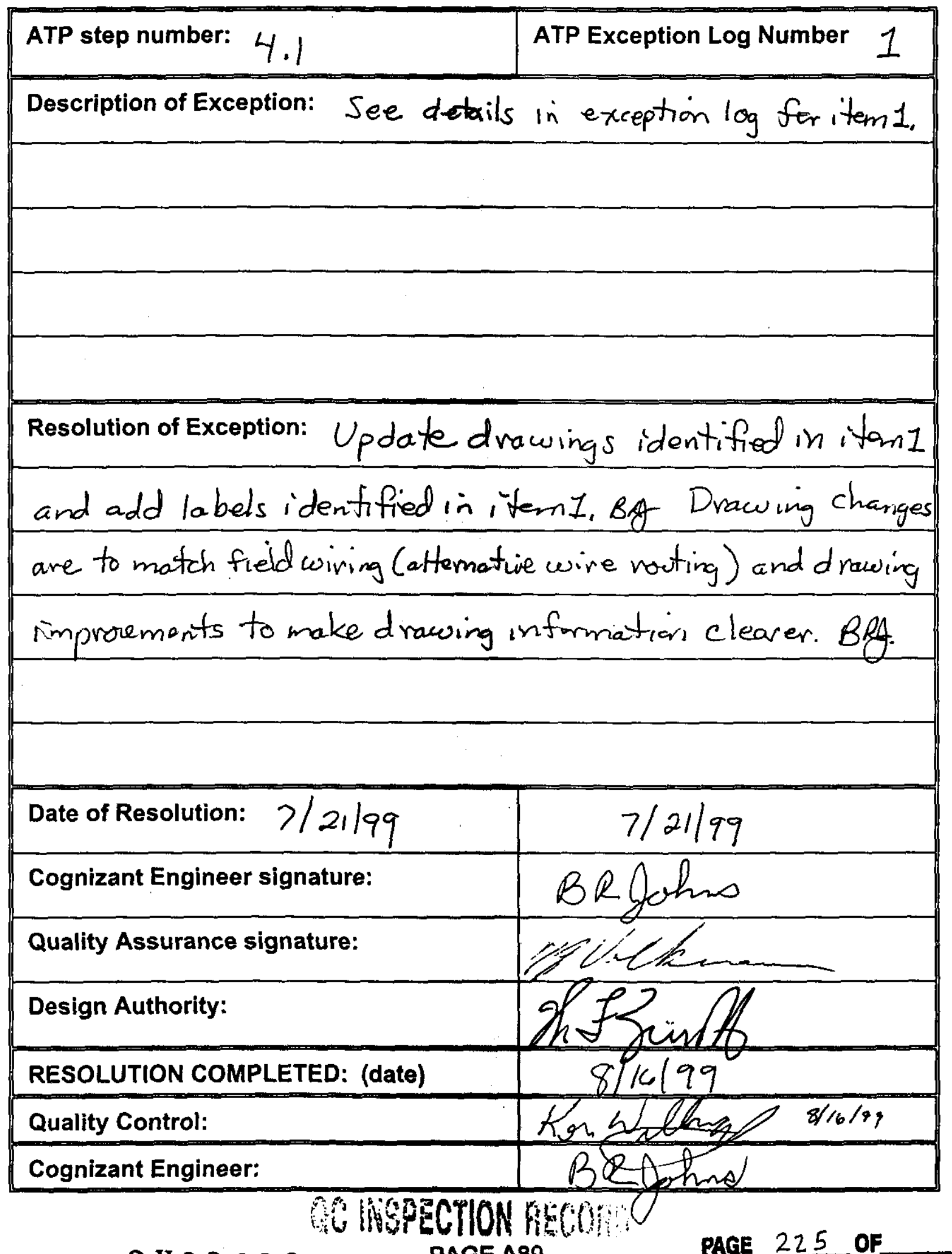


HNF-4277

REVISION 0

ACCEPTANCE TEST PROCEDURE EXCEPTION RECORD

This page may be reproduced as necessary.

\begin{tabular}{|l|l|}
\hline ATP step number: 4.4 .2 .8 & ATP Exception Log Number 2 \\
\hline Description of Exception: Valve $S A L W-V-6043 \mathrm{~K}$ \\
\hline Was missing from valve list. \\
\hline \\
\hline Resolution of Exception: Added Valve SALW-V -6043 K \\
\hline
\end{tabular}

to list of valves to be closed. This value is the air compressor tank drain value.

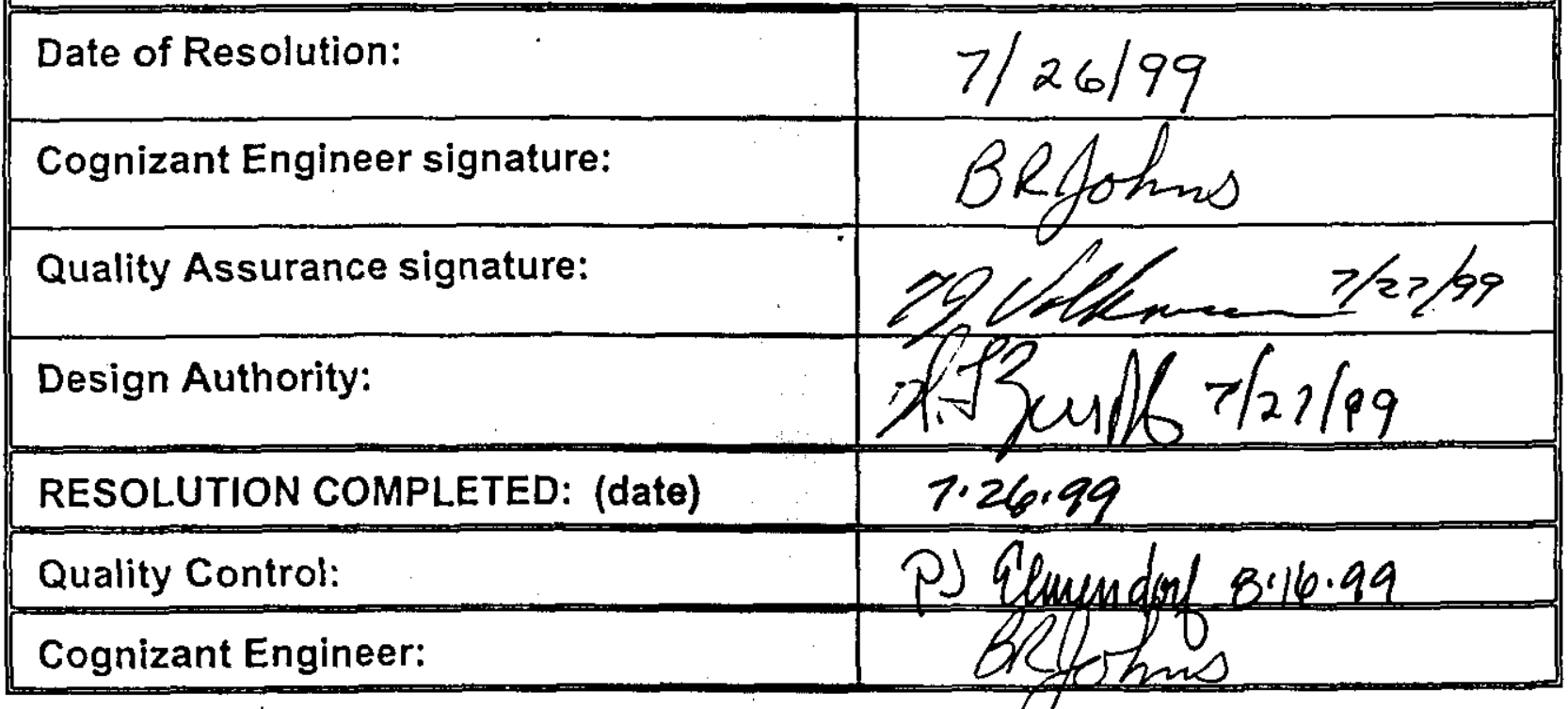

OC IASPECTIINN RECORD

WORK ORDER

2 H9903385 F

PACE 234 OF 
HNF-4277

REVISION 0

ACCEPTANCE TEST PROCEDURE EXCEPTION RECORD

This page may be reproduced as necessary.

\begin{tabular}{|l|l|}
\hline ATP step number: 5.1 .5 & ATP Exception Log Number 3 \\
\hline
\end{tabular}

Description of Exception: Clarification of step to measure continuity of primary side wires to lokva transformer.

Resolution of Exception:

Measure continuity for the transformer primary side wires by measuring between the two phases at the line side of: the transformer disconnect switch. This will check continuity through the wires, and connections and transformer primary coil.

\begin{tabular}{|l|c|}
\hline Date of Resolution: & $2 / 26 / 99$ \\
\hline Cognizant Engineer signature: & \\
\hline Quality Assurance signature: & \\
\hline Design Authority: & \\
\hline RESOLUTION COMPLETED: (date) & $7 / 26.99$ \\
\hline Quality Control: & PI \\
\hline Cognizant Engineer: & \\
\hline
\end{tabular}

OC INSPECTION RECONS

WORK ORDER 2 H9903385 F

PAGE A91

page ?35 of 
HNF-4277

REVISION 0

ACCEPTANCE TEST PROCEDURE EXCEPTION RECORD

This page may be reproduced as necessary.

\begin{tabular}{|l|l|}
\hline ATP step number: 5.1 .6 & ATP Exception Log Number 4 \\
\hline Description of Exception: Clarification of step to \\
\hline measure continuity of secondary side wires \\
\hline between the 10kva transformer and panel board \\
\hline
\end{tabular}

Resolution of Exception:

Measure continuity at the panelboard by measuring between the two wires at the panelboard bus. This will check continuity through the two wives going to the transformer secondary, connections and transformer secondary coil. Lift the neutral lead and verify no short to ground between the hot leads and ground. Date of Resolution:

$7 / 26 / 99$

Cognizant Engineer signature:

BR fores

Quality Assurance signature:

Design Authority:

RESOLUTION COMPLETED: (date)

7.26 .99

Quality Control:

PJ Gluendin B.16.99

Cognizant Engineer:

BRTohns

QC MERECTINN RECORD

PAGE A92

WORK ORDER $2 \mathrm{H} 9903385 \mathrm{~F}$

DANE

$7=1$

ne 
HNF-4277

REVISION 0

ACCEPTANCE TEST PROCEDURE EXCEPTION RECORD

This page may be reproduced as necessary.

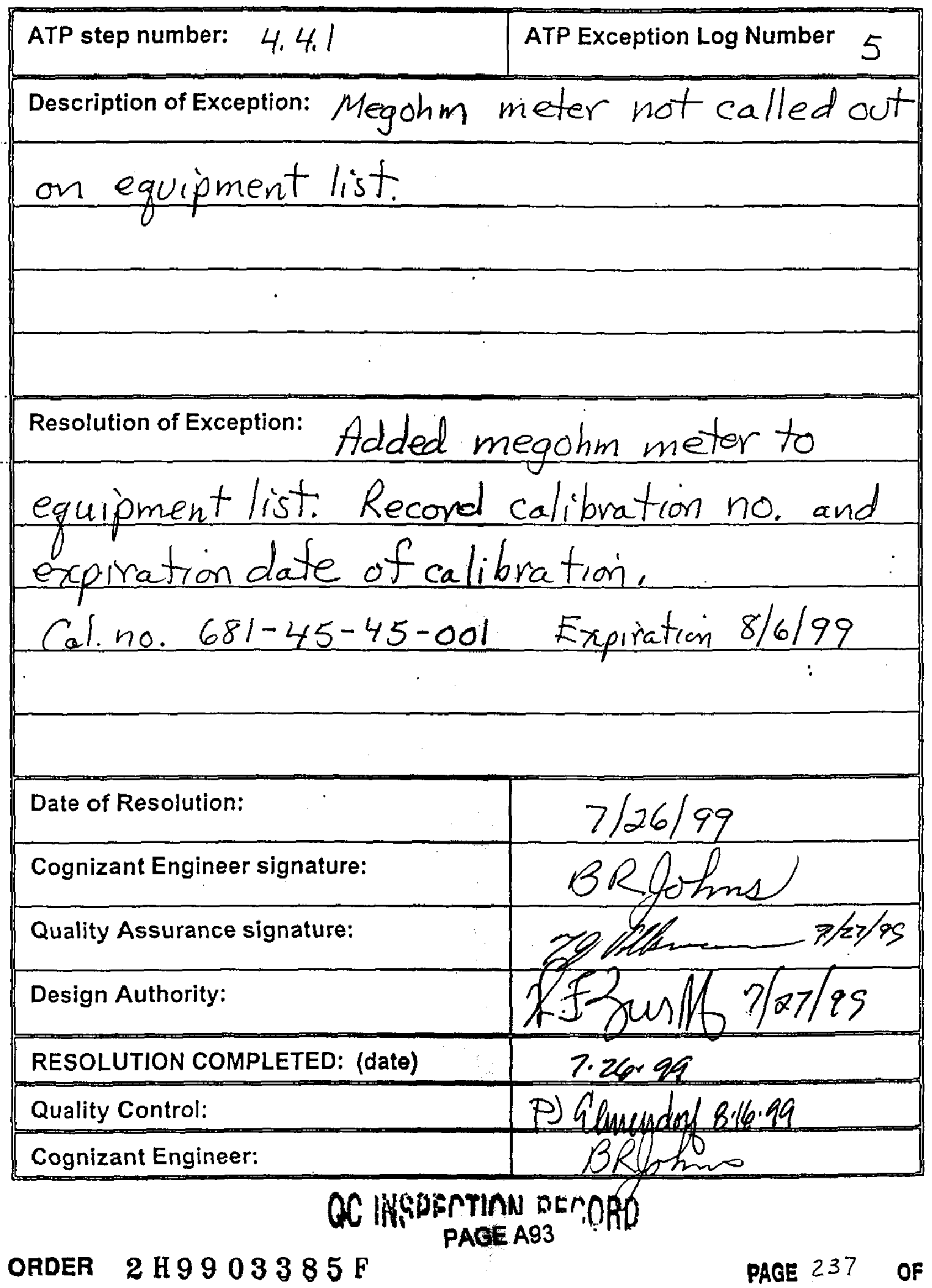


NF -4277

REVISION 0

ACCEPTANCE TEST PROCEDURE EXCEPTION RECORD

This page may be reproduced as necessary.

\begin{tabular}{|l|l|l|}
\hline ATP step number: $5.2 .3+5.2 .4$ & ATP Exception Log Number 6 \\
\hline
\end{tabular}

Description of Exception:

Can not mugger the $A$ and $B$ phases between each other since connected to the trans former!

Resolution of Exception:

Delete the meggercheck to going between phases A and B since it will be a short due to connection to transformer.

It is not practical to un tape and break connections at transformer. There is no value added by performing this step.

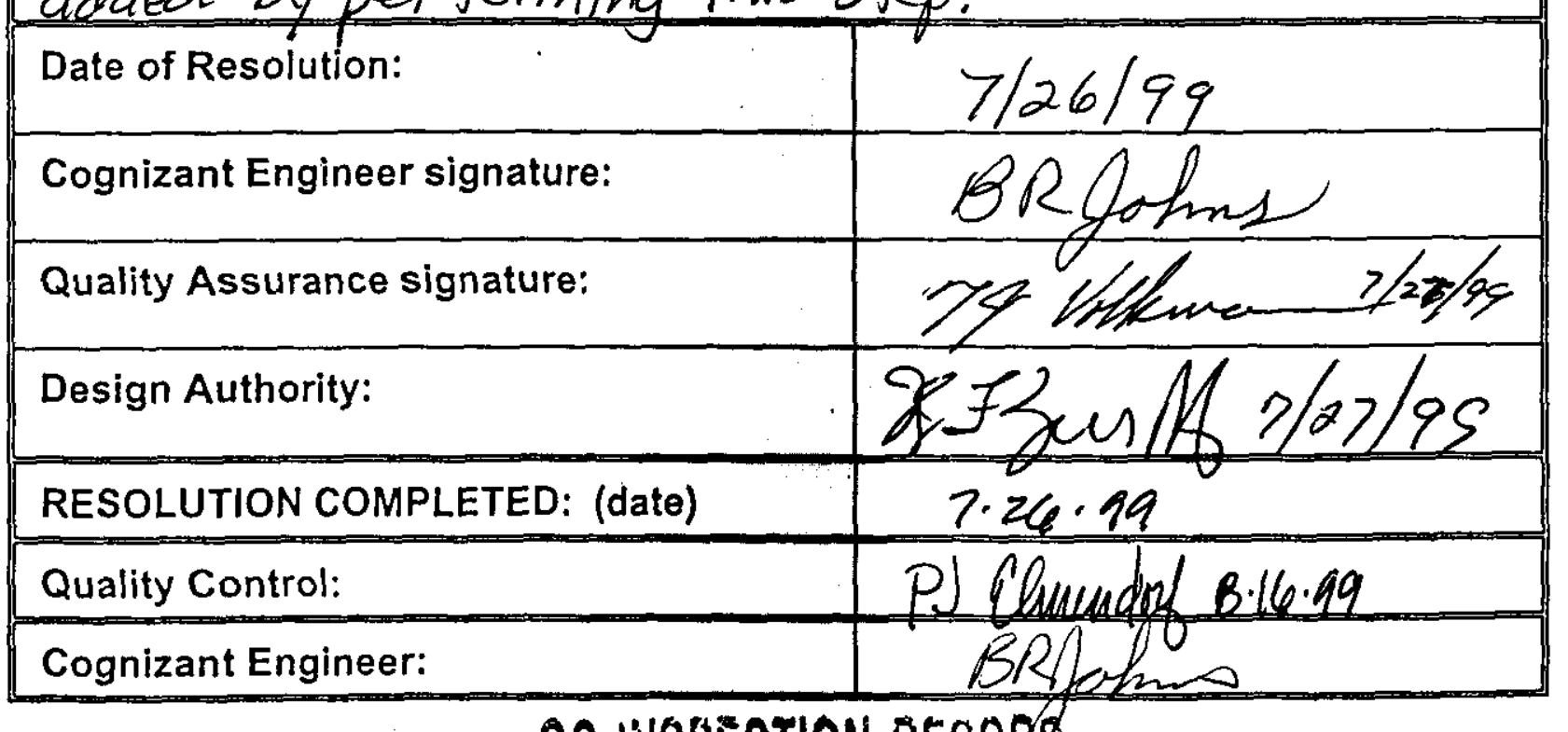

QC MSGPECTION RECORd

PAGE A94

WORK ORDER 2 H9903385F

PAGE 238 OF 
INF- -4277

REVISION 0

ACCEPTANCE TEST PROCEDURE EXCEPTION RECORD

This page may be reproduced as necessary.

\begin{tabular}{|l|l|}
\hline ATP step number: $5,2,5$ & ATP Exception Log Number 7 \\
\hline
\end{tabular}

Description of Exception:

Can not meager between phases with motor connected.

Resolution of Exception: Delete this portion of the step.

Meggering between phases when connected to the motor is a short. It is not practical and no value added by in taping and breaking connections to perform this part of the slop.

Mugger check between phases and ground is sufficient. Date of Resolution:

7/26/99

Cognizant Engineer signature:

Brofohns

Quality Assurance signature:

Design Authority:

Quality Control:

$7.26 \cdot 99$

Cognizant Engineer:

PJGlimende 8.16 .99

OC WSPECTION RECORD

PAGE A95

WORK ORDER 2 H9903385 F

PAGE 239 OF 
HNF-4277

REVISION 0

ACCEPTANCE TEST PROCEDURE EXCEPTION RECORD

This page may be reproduced as necessary.

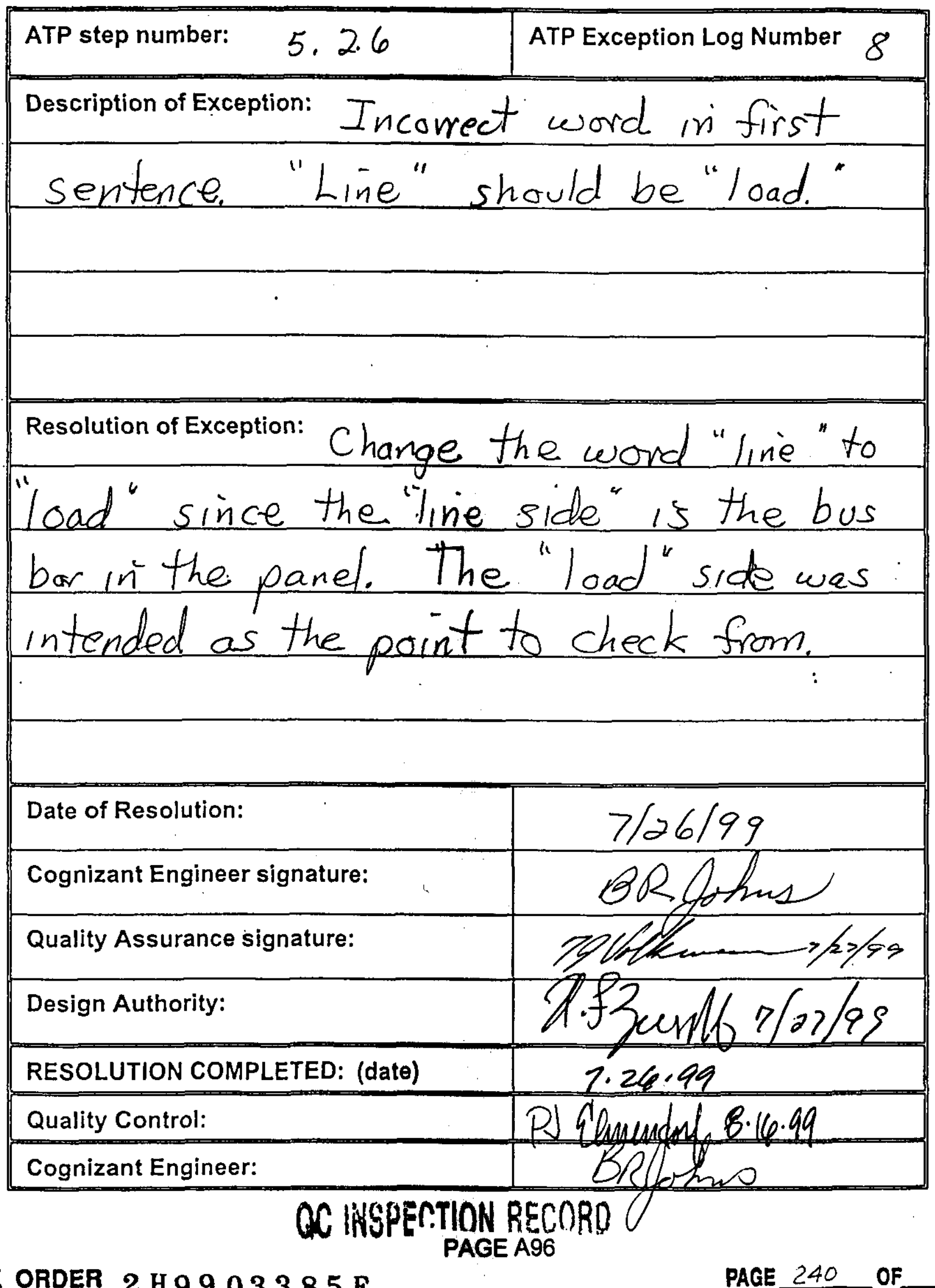

WORK ORDER 2 H $9903385 \mathrm{~F}$

PAGE $240 \quad 0$ 
HNF-4277

REVISION 0

ACCEPTANCE TEST PROCEDURE EXCEPTION RECORD

This page may be reproduced as necessary.

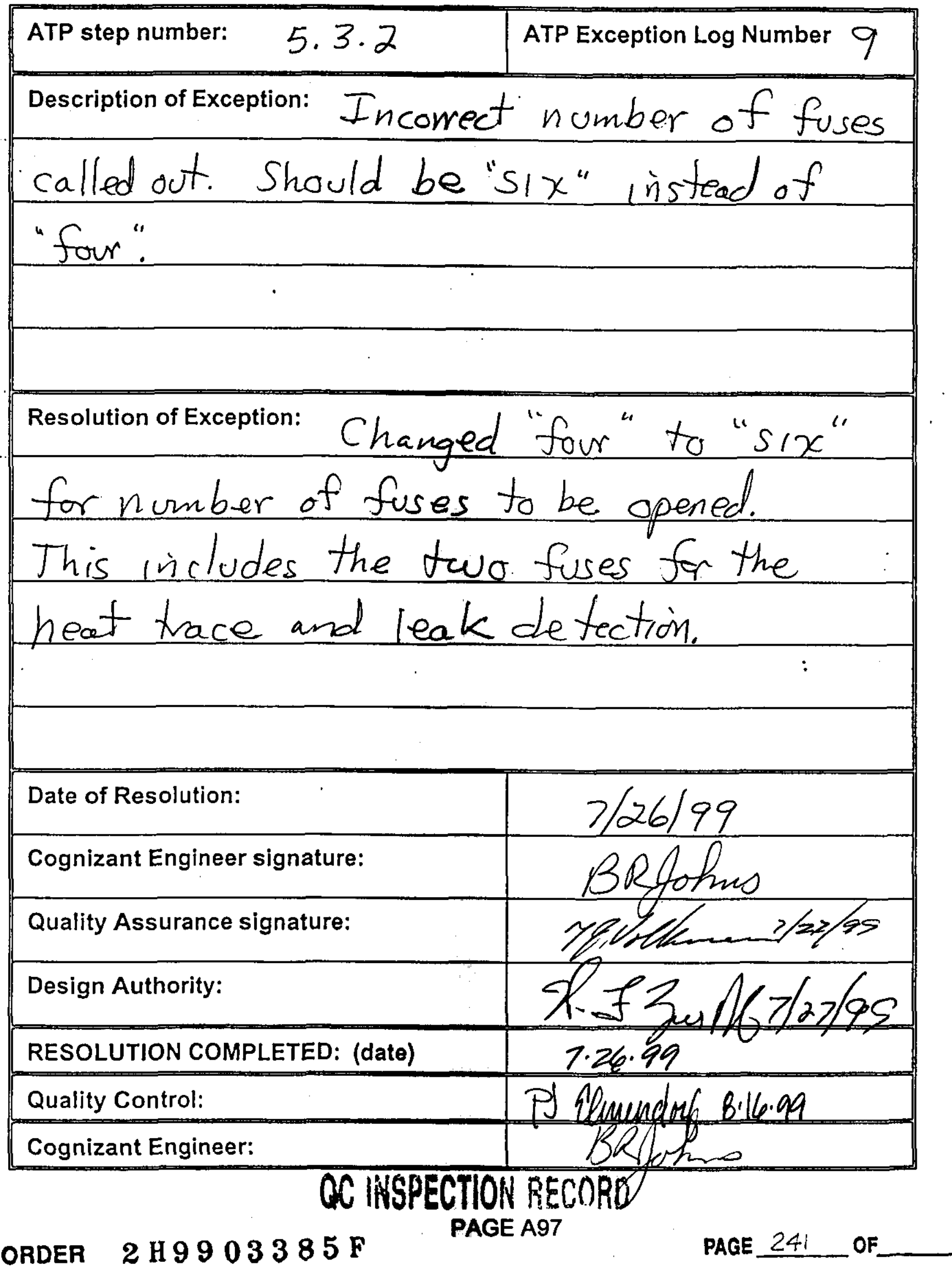

WORK ORDER $2 \mathrm{H} 9903385 \mathrm{~F}$

PAGE 241 OF 
HNF-4277

REVISION 0

ACCEPTANCE TEST PROCEDURE EXCEPTION RECORD

This page may be reproduced as necessary.

\begin{tabular}{|l|l|}
\hline ATP step number: 5.3 .45 & ATP Exception Log Number 10 \\
\hline
\end{tabular}

Description of Exception: Check 24vdc power supplies.

Resolution of Exception: Added steps to check the input voltage to the $2 y v d c$ power supplies of $120 \mathrm{Vac} \pm 10 \mathrm{vac}$; check the output voltage of the power supplies of $24 \mathrm{Vdc} \pm 2 \mathrm{vdc}$. This ensure proper power to the instruments needing $24 \mathrm{vdc}$.

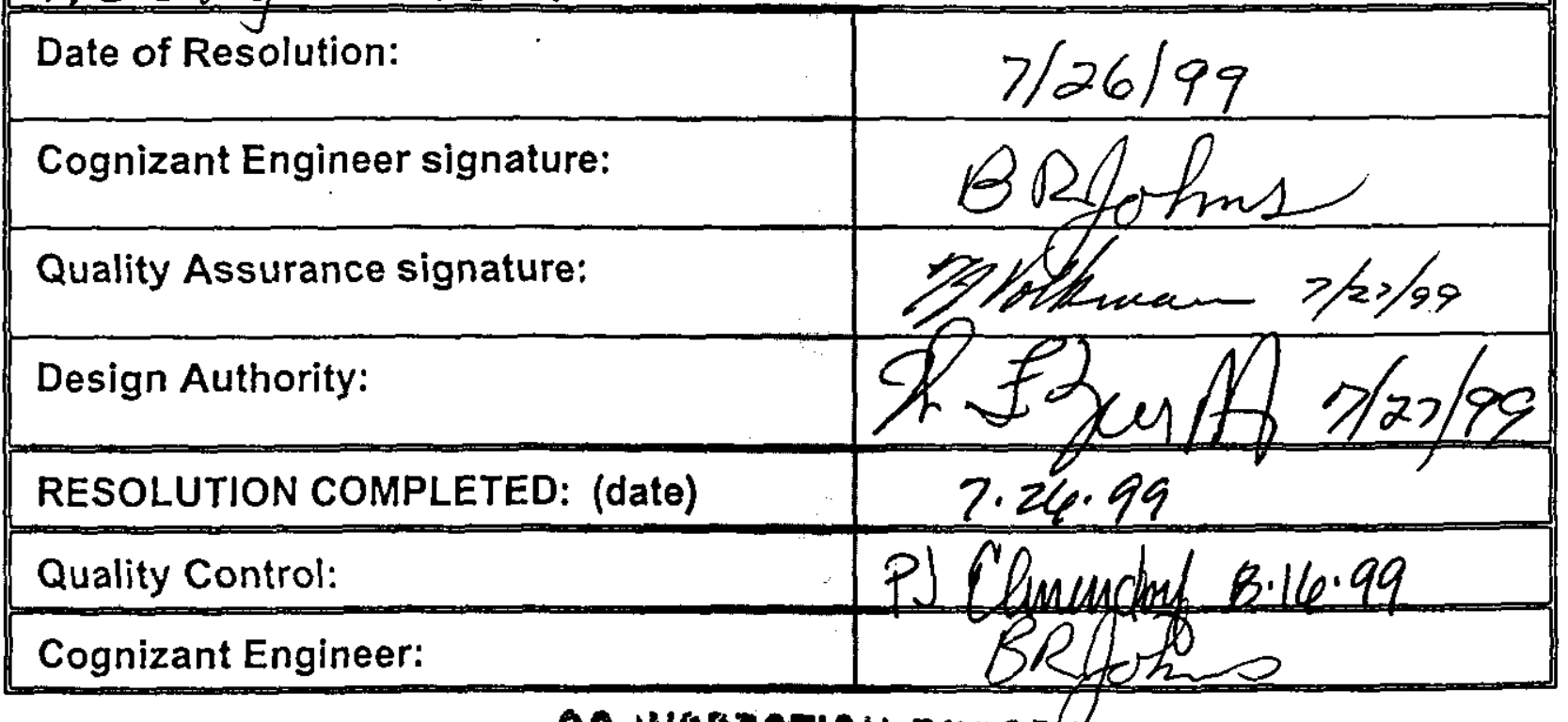

QC IASPFC.TINN BFCORP

WORK ORDER $2 H 9903385$ F PAGE A98

PAGE 242 OF 
INF -4277

REVISION 0

ACCEPTANCE TEST PROCEDURE EXCEPTION RECORD

This page may be reproduced as necessary.

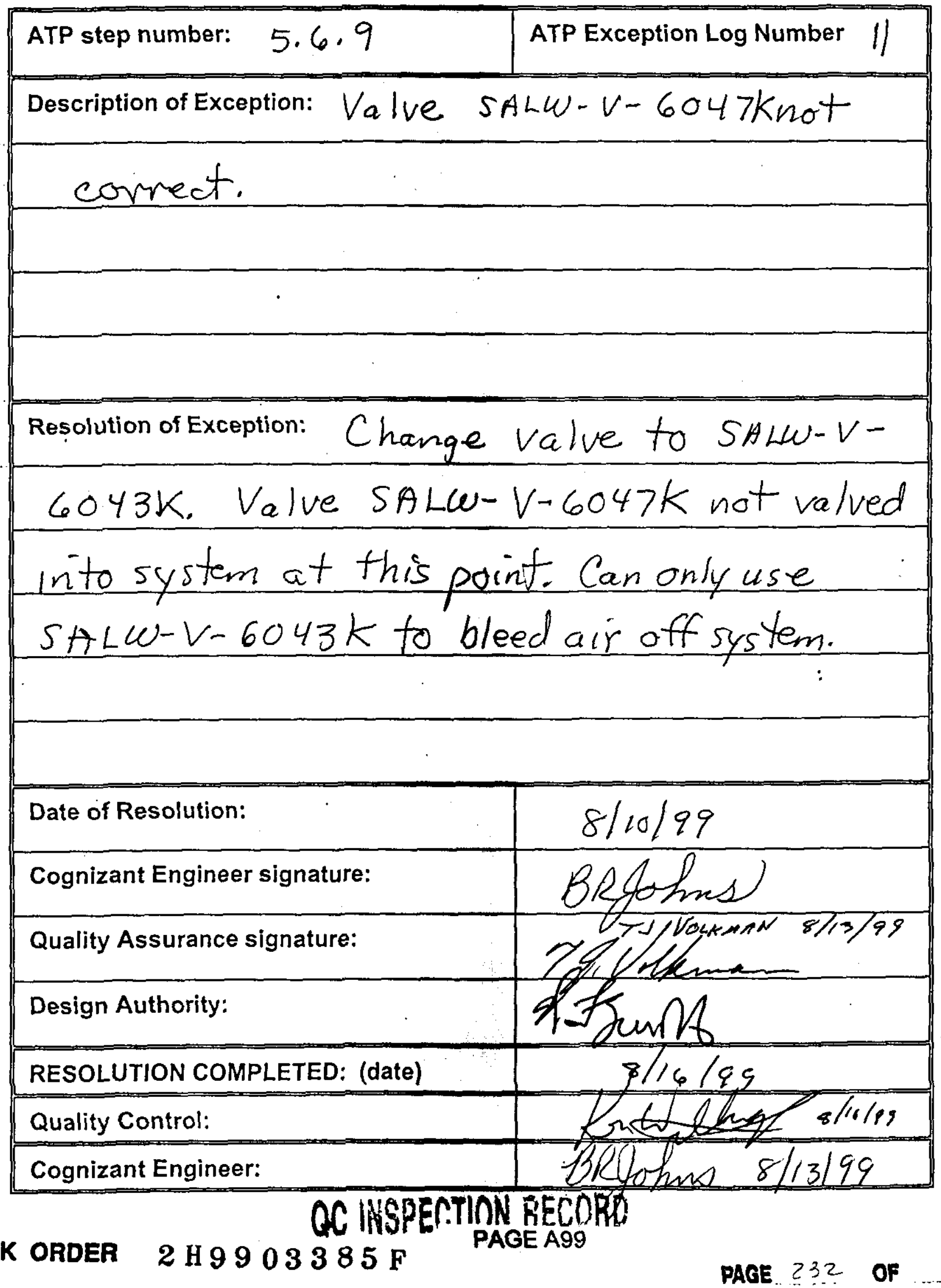


HNF-4277

REVISION 0

ACCEPTANCE TEST PROCEDURE EXCEPTION RECORD

This page may be reproduced as necessary.

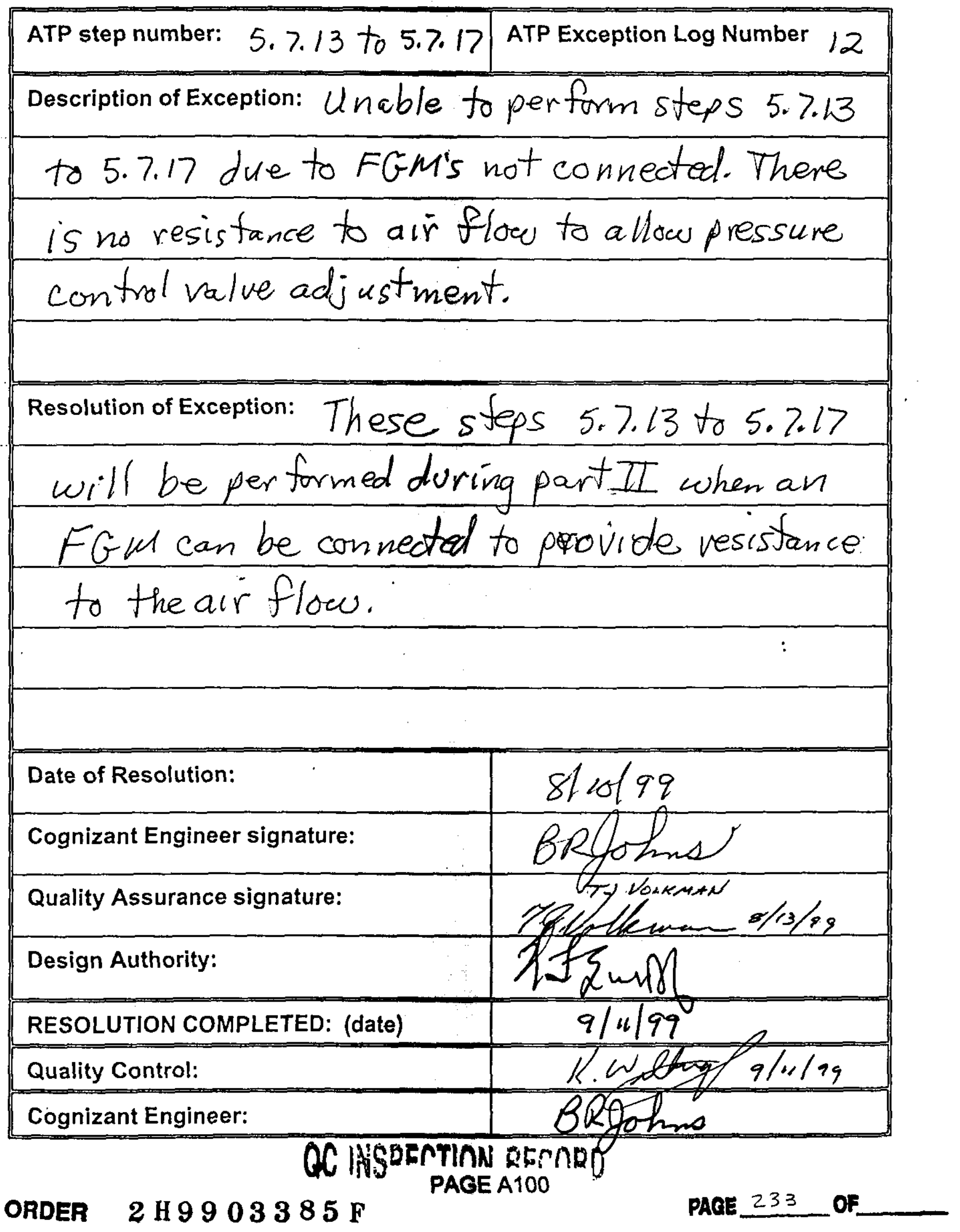


HNF-4277

REVISION 0

ACCEPTANCE TEST PROCEDURE EXCEPTION RECORD

This page may be reproduced as necessary.

\begin{tabular}{|l|l|l|}
\hline ATP step number: $5,8,4$ to $5,8,6$ & ATP Exception Log Number 13 \\
\hline
\end{tabular}

Description of Exception: Unable to connect manometer to high side pressure port.

Resolution of Exception:

Connect manometer to low side port, open high side to atmosphere. Place vacuum on low side to create pressure on high side. Manometer is calibrated for vacuum. See a Hacked calibration report. vacuum pressure required for this test was 62 " favater max

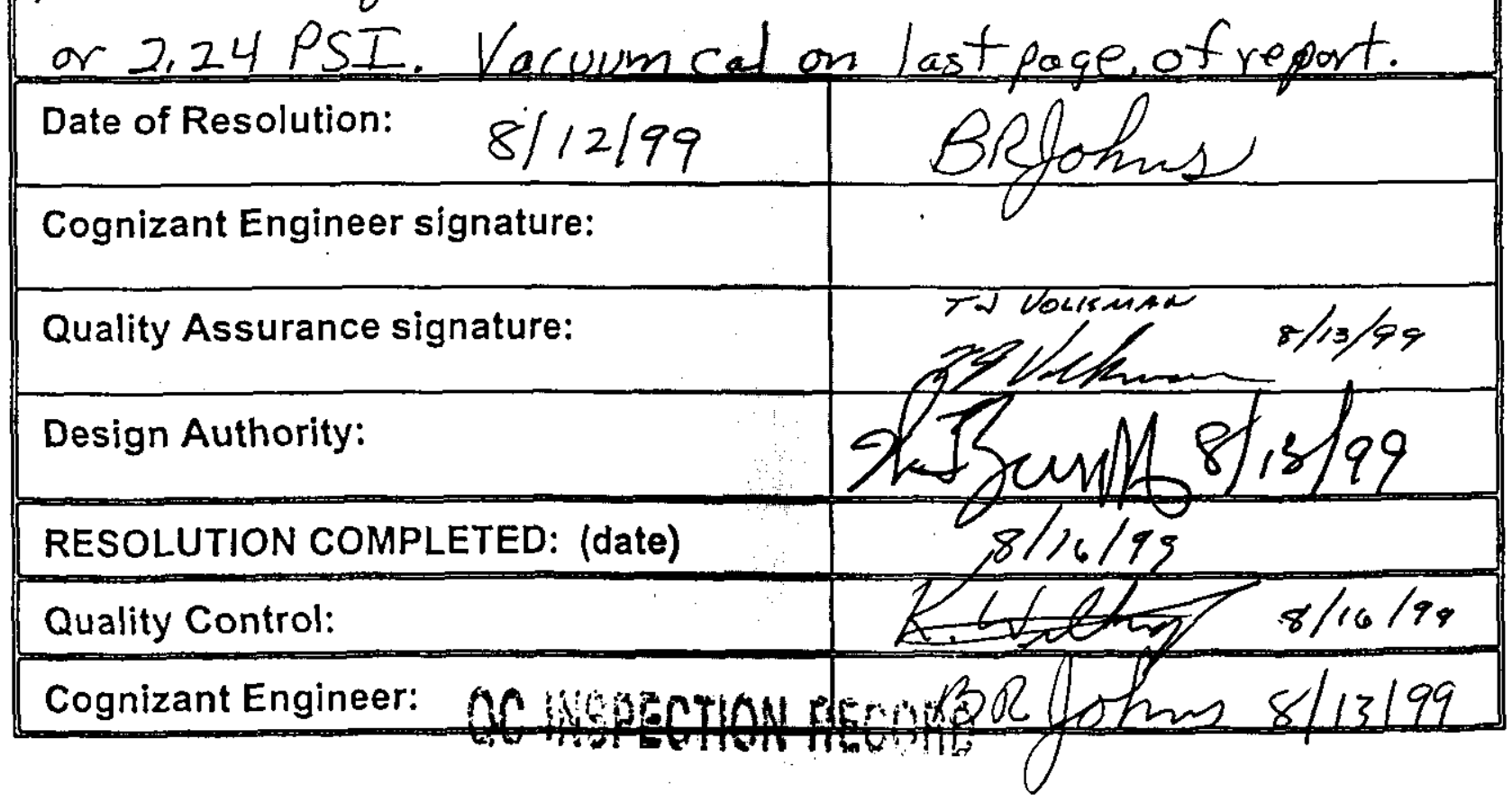

WORK ORDER $2 \mathrm{H} 9903385 \mathrm{~F}$

PAGE A101

PAGE 243 OF 
CUSTODIAN/ADDRESS

HALL JC

S7 -20

INSTRUMENT

PRESSURE INDICATOR

DRUCK DPI610

$0-300$ PSIG

SENDER

J HALL $3-8488$

INSTRUMENT SPECIFICATIONS

HANFORD STANDARDS LABORATORY CALIBRATION REPORT

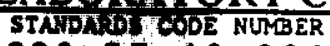

$820-35-40-004$

SERIAL, NUTBER

6100987903 ROOM BUILDING

$\mathrm{N} / \mathrm{A}$ COMGENTS $2703 E$

\section{PROPERTY NUMMER \\ $N / A$ \\ BARVICE DEPARTMENT 5}

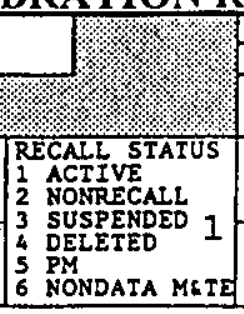

NEW

\begin{tabular}{l|l|l|}
\hline & REFERENCE NUMBER
\end{tabular}

\begin{tabular}{l|l} 
& 420371 \\
\hline
\end{tabular} 79400

RECAIL CYCLE TOLERANCE HISTORY

360

DATE RECEIVED

990106

\begin{tabular}{|l|c|c|}
\hline RUSH & CO ID & SO \\
NO & 7 & TH \\
\hline
\end{tabular}

INO

TRAINING HOURS

ACTUAL CAL, HRS

OTHER BOURS

ENC/ADMIN HOURS

Scandard(s) used In calfbration traceable to National Institute
of 5 tandards and Technology or natlonally recognized standards.

EXPIRATION DATE

Q TYY RATIO?

EXPIRATION DATE

BILLED

STD CAL HOURS

REPAIR HOURS

MATERIALS

$\overline{\text { REMAVXS }}$

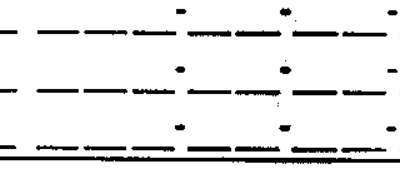

PROCEDURE NUTEER

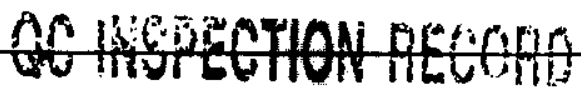

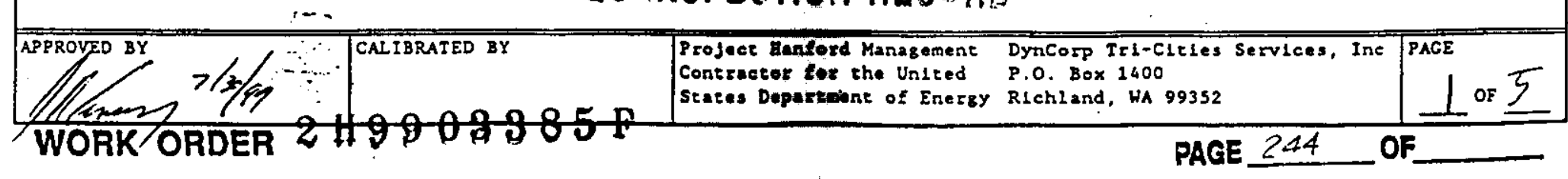


Date: $\quad$ March 31, 1999

TO: $\quad$ HSL Customers, File

From:

J.R. Emery, Mgr., HSL

Subject: HSL Calibration Reports

On June 18,1998 , the performance of M\&TE calibrations by the HSL was suspended. On that same date, off-site calibration facilities began the calibration of HSL customer M\&TE via Purchase Order or Contract Requisition.

When returned to the site after calibration, the M\&TE is accompanied by a vendor calibration certification. The veridor certification includes pertinent information relating to each respective calibration. This includes the following: traceability, compliance to ANSI/NCSL Z540-1-1994 or other national calibration or quality standards, calibration ratio, as-found and as-left data (as applicable), range(s), tolerance(s), date calibrated, calibration frequency, date due for recalibration, person performing the calibration, outof-tolerance data and limiting conditions of use (as applicable), and any other information relative to the calibration.

: :

When the vendor certification is received, the HSL attaches an HSL Calibration Report to the vendor documentation. The HSL Calibration Report primarily serves as the device for updating the HSL SLIC Database for future recall of the M\&TE for calibration.

As of this date, the following information will be annotated on the HSL Calibration Report: vendor compliance to 4:1 calibration ratio, M\&TE status (Active, Suspended, Rejected, etc.), date of the calibration, date M\&TE is due for recalibration, tolerance as received, calibration history (up to the last four calibrations), and the signature, date and stamp of the HSL engineer who performed the review. All other information relative to the calibration is contained in the vendor's certification. All pages of the completed report will be pagenated.

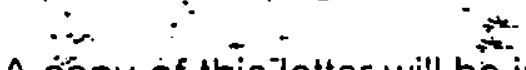

A copy of this letter will be incorporated into each HSL Calibration Report.

PAGE A103

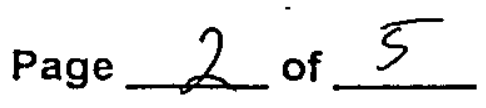


HNF-4277

REVISION 0
152 $820.35-40.004$

Belhaven

Applied Technologies Customer Dyncorp PO\# 3914

\section{Certificate of Calibration}

Tag 820-35-40-004 Model DPI610 Manufacturer Druck

Instrument Pressure Indicator Serial No 6100987903

Calibration traceable to the National Institute of Standards and

Technology in accordance with ANSI- Z540.1 has been accomplished on the above-named instrument by comparison with standards maintained by Belhaven. The accuracy and stability of all standards maintained by Belhaven are traceable to national standards maintained by the National Institute of Standards and Technology in Washington, D.C. and Boulder, Colorado.

Temperature at Calibration:

Accuracy of instrument

Calibrated Range:

Calibration Report No.

Date Due: $777 / 2000^{\circ}$

Test Equipment

Paroscientific Pressure Standard S/N 224

Prema Multi-Function Meter.S/N10012
$68 \mathrm{~F}$

See Report

See Report

BEL89-620

Calibrated by:

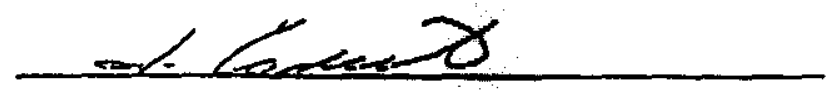

Certified by:

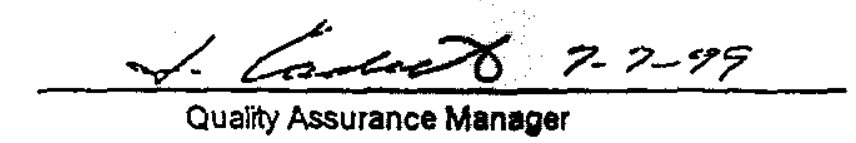

PACE 246

PAGE A104 
HNF-4277

REVISION 0

\section{$820-35.40-004$ \\ Belhaven \\ Applied Technologies Inc.}

415 N. Quay, Kennewick, WA 99336 Voice (509) 735-9446 - Fax (509) 735-3733

\section{Druck Pressure Indicator (DPI 610) Calibration Form}

Calibration Report Number:

Client:

Purchase Order Number:

Tag ID Number:

Serial Number:

Test Equipment Used:
BEL99-620

\begin{tabular}{l} 
Dyncorp \\
\hline 3914 \\
\hline $820-35-40-004$ \\
\hline 6100987903 \\
Paroscientific Pressure Standard, S/N: 224 \\
Prems Multi-Function Mcter, S/N: 10012 \\
\hline
\end{tabular}

Voltage Input Calibration (0-50 VDC): (Accuracy $=+1-0.05 \%$ RDG $+1-0.004 \%$ FS)

\begin{tabular}{|c|c|c|c|c|}
\hline Applied Voltage (V) & Lower Limit (V) & As found $(V)$ & As Left (V) & Upper Limit (V) \\
\hline 10.0000 & 9.993 & 9.999 & 9.999 & 10.007 \\
\hline 19.9995 & 19.988 & 19.996 & 19.996 & 20.010 \\
\hline 29.9996 & 29.982 & 29.995 & 29.995 & 30.016 \\
\hline 39.9997 & 39.977 & 39.994 & 39.994 & 40.021 \\
\hline 49.9998 & 49.972 & 49.992 & 49.992 & 50.026 \\
\hline
\end{tabular}

Voltage Output Calibration: (Accuracy $=24 \mathrm{~V}+/-5 \%, 10 \mathrm{~V}+1-0.1 \%$ )

$\therefore$\begin{tabular}{|c|c|c|c|c|}
\hline Output Voltage $(V)$ & Lower Limit $(V)$ & As found $(V)$ & As Left $(V)$ & Upper Limit $(V)$ \\
\hline 10 & 9.99 & 9.9912 & 9.9912 & 10.01 \\
\hline 24 & 22.80 & 24.0035 & 24.0035 & 25.20 \\
\hline
\end{tabular}

Current Input Calibration ( $0-55 \mathrm{~mA}):($ Accuracy $=+1-0.05 \%$ RDG $+1-0.004 \%$ FS)

\begin{tabular}{|c|c|c|c|c|}
\hline $\begin{array}{c}\text { Applied Current } \\
(\mathrm{mA})\end{array}$ & $\begin{array}{c}\text { Lower Limit } \\
(\mathrm{mA})\end{array}$ & As found (mA) & As Left (mA) & Upper Limit (mA) \\
\hline 11.0018 & 10.994 & 11.000 & 11.000 & 11.009 \\
\hline 22.0010 & 21.987 & 22.000 & 22.000 & 22.014 \\
\hline 33.0009 & 32.982 & 33.000 & 33.000 & 33.019 \\
\hline 44.0008 & 43.976 & 44.000 & 44.000 & 44.025 \\
\hline $55.0011^{-}$ & 54.971 & 55.001 & 55.001 & 55.030 \\
\hline
\end{tabular}

Pressure Calibration: (Accuracy $=+1-0.025 \%$ ES $)$

\begin{tabular}{|c|c|c|c|c|}
\hline Applied Pressure (PSI) & Lower Limit (PSI) & As found (PSI) & As Left (PSI) & Upper Linit (PSI) \\
\hline 59.9995 & 59.92 & 60.03 & 60.03 & 60.07 \\
\hline 119.9968 & 119.92 & 120.02 & 120.02 & 120.07 \\
\hline 180.0244 & 179.94 & 180.08 & 180.08 & 180.09 \\
\hline 240.0162 & 239.94 & $\mathbf{2 4 0 . 0 6}$ & 240.06 & 240.09 \\
\hline 299.0876 & 299.01 & 299.14 & 299.14 & 299.16 \\
\hline
\end{tabular}

NOTE: The other two pressure scales and linearity error should automatically be within specification according to the factory user manual KA0 +9 Issue 7, pg. 13. 
HNF-4277

REVISION 0
$820-35.40-004$

Belhaven..

Applied Technologies

415 N. Quay, Kennewick, WA 99336 Voice (509) 735-9446 - Fax (509) 735-3733

420371

Vacuum Calibration: (Accuracy $=+1-0.025 \%$ TS)

\begin{tabular}{|c|c|c|c|c|}
\hline Applied Pressure (PSI) & Lower Limit (PSI) & As found (PSI) & As Left (PSI) & Upper Limit (PSI) \\
\hline-2.0444 & -1.969 & -2.05 & -2.05 & -2.119 \\
\hline-3.9915 & -3.916 & -4.00 & -4.00 & -4.066 \\
\hline-6.0505 & -5.975 & -6.03 & -6.03 & -6.125 \\
\hline-8.0085 & -7.933 & -8.00 & -8.00 & -8.083 \\
\hline-10.0385 & -9.963 & -10.04 & -10.04 & -10.113 \\
\hline
\end{tabular}

Calibration Performed By:

Jeff Cadick $=<-2-9$

ORIGINAL

OC InSPECTION RECOCFO

PAGE A106

NARK ORDER 2 H9903385 F

PAGE 248 OF

ก 529 
HNF-4277
REVISION O

ACCEPTANCE TEST PROCEDURE EXCEPTION RECORD

This page may be reproduced as necessary.

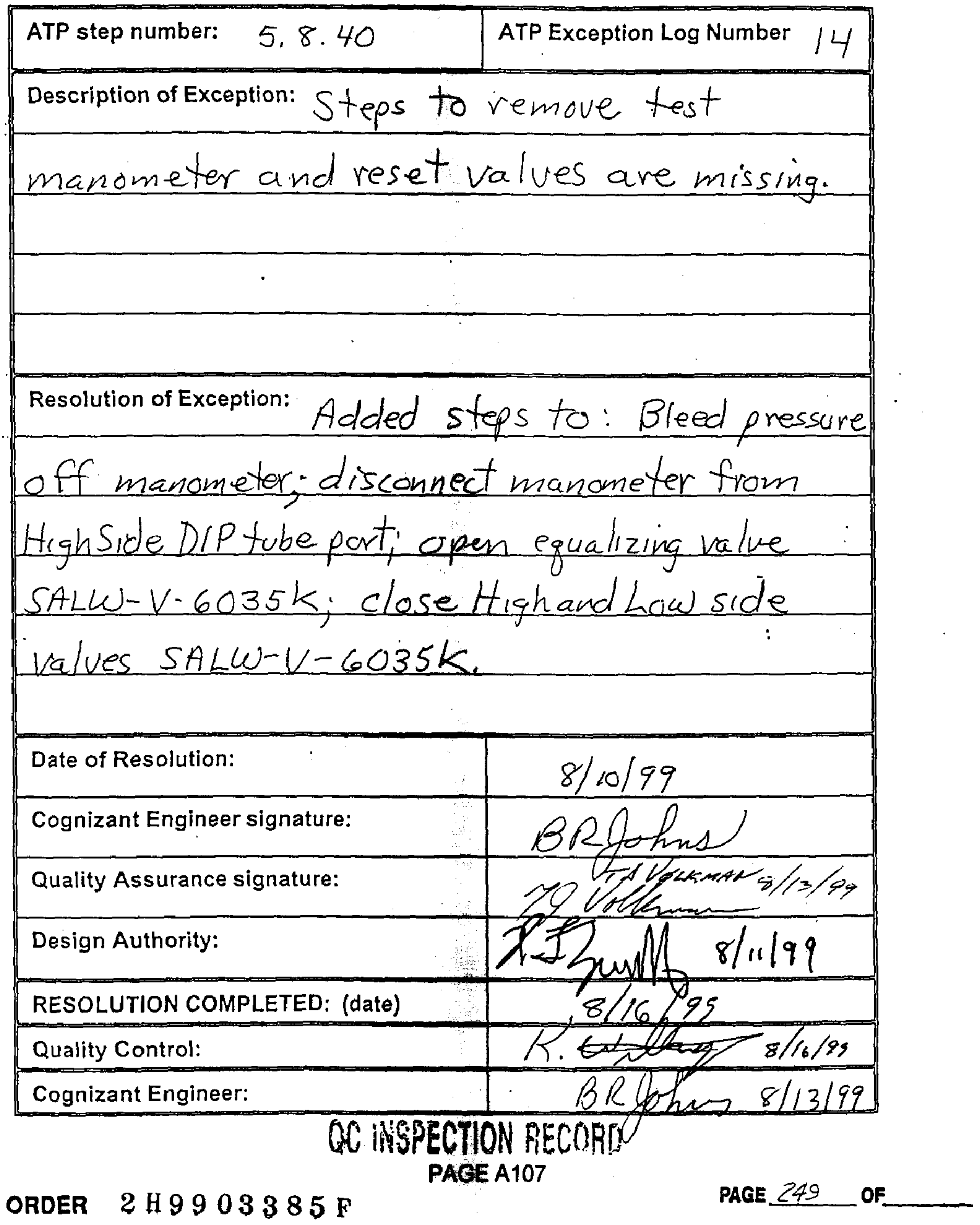


HNF-4277
REVISION O

ACCEPTANCE TEST PROCEDURE EXCEPTION RECORD

This page may be reproduced as necessary.

\begin{tabular}{|ll|l|}
\hline ATP step number: 5.9 .15 & ATP Exception Log Number 16 \\
\hline
\end{tabular}

Description of Exception:

Amber light came on immediately. Alar only was 30 second delay.

Resolution of Exception: Corrected step to read that amber light comes ON immediately. Rechecked software logic and compared to other skid: logic and the amber light logic is correct. Only the alarm has the 30 second delay.

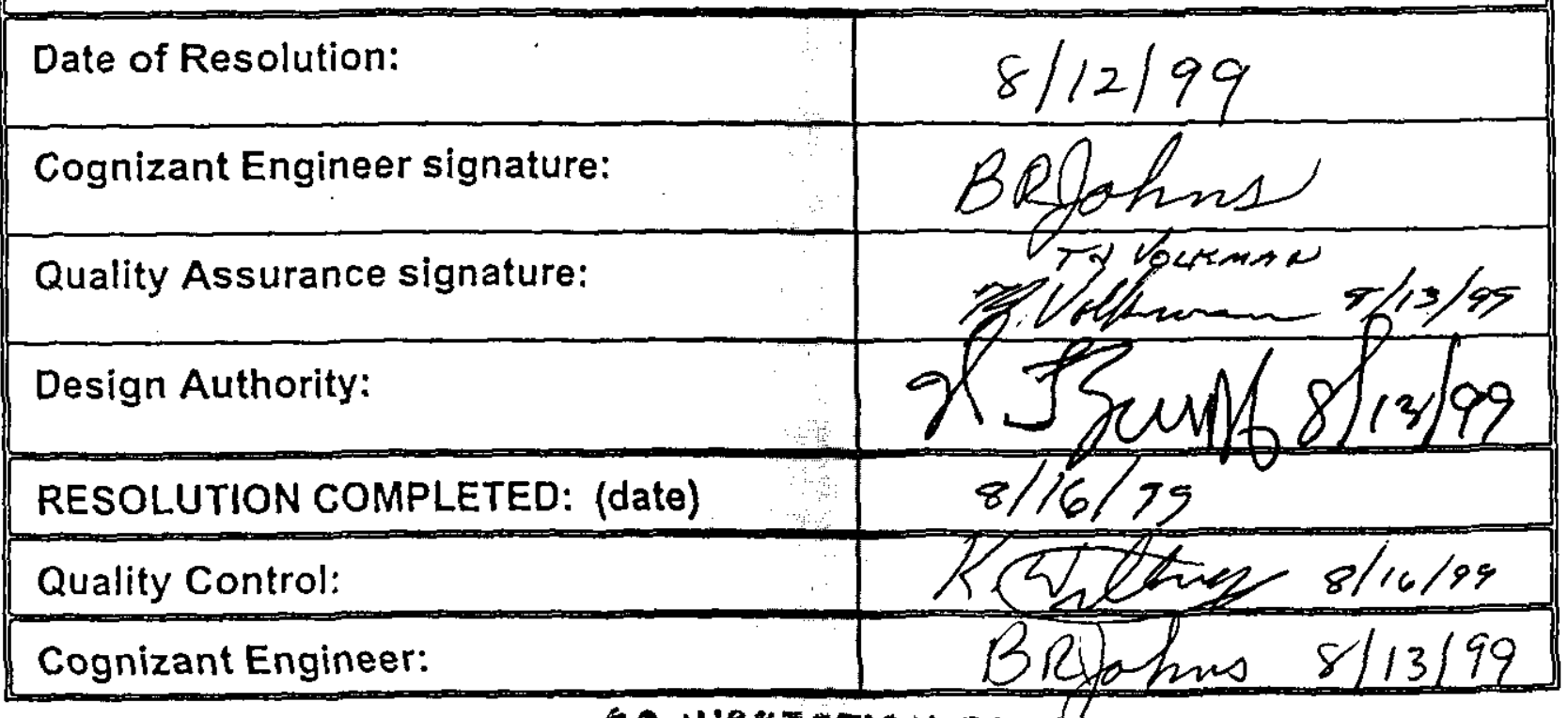

OC MSPECTION RECORD

PAGE A108

WORK ORDER $2 H 9903385 \mathrm{~F}$

PAGE $25 \mathrm{C}$

OF 
HNF-4277

REVISION 0

ACCEPTANCE TEST PROCEDURE EXCEPTION RECORD

This page may be reproduced as necessary.

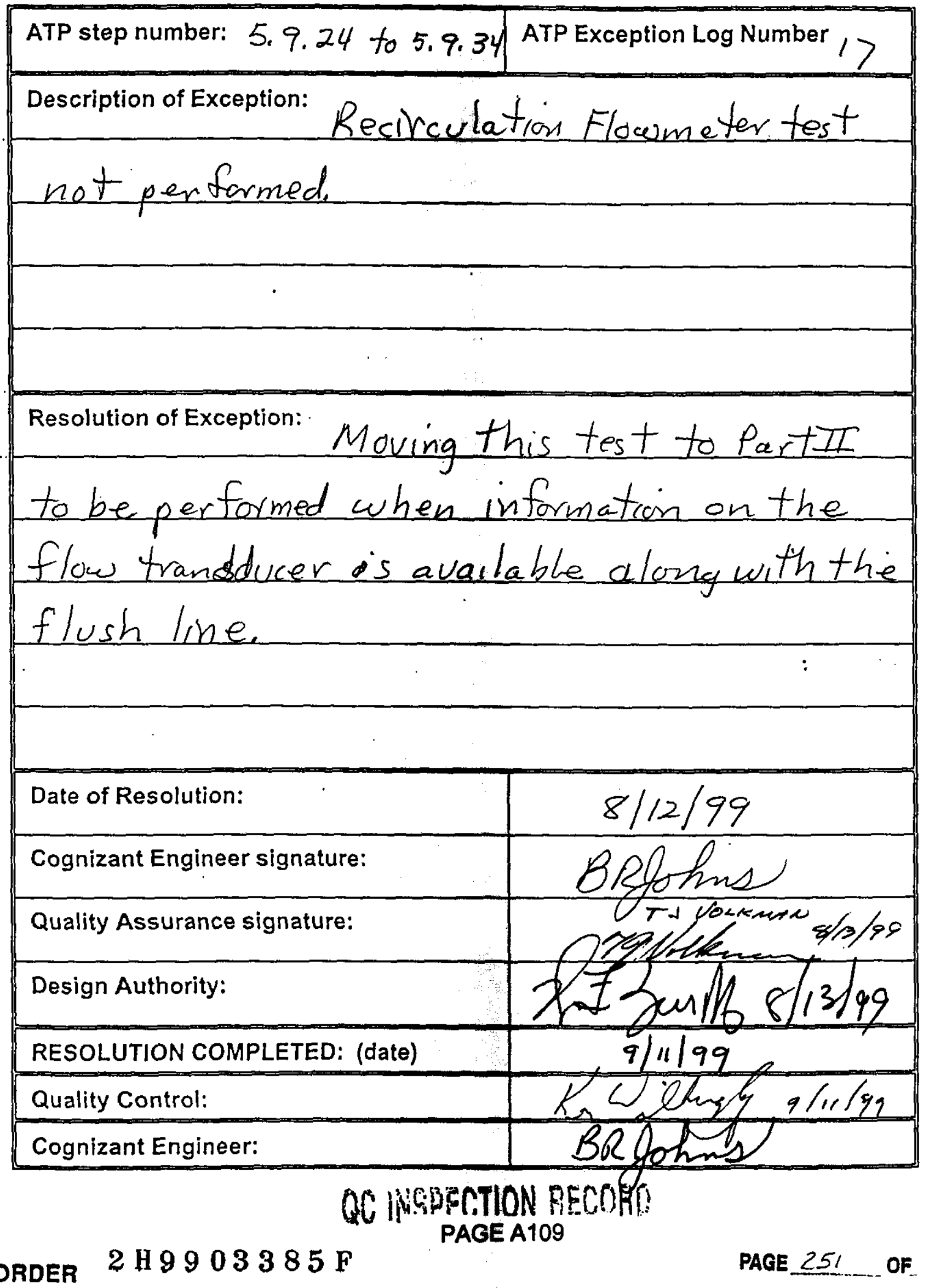


NF- 4277

REVISION 0

ACCEPTANCE TEST PROCEDURE EXCEPTION RECORD

This page may be reproduced as necessary.

\begin{tabular}{|l|l|}
\hline ATP step number: Section' 5.11 & ATP Exception Log Number 19 \\
\hline Description of Exception: Leak detection not per formed. \\
\hline \\
\hline \\
\hline Resolution of Exception: Leak detection CGI was performed \\
\hline
\end{tabular}

under procedure HNF-4275, and was completed and witnessed by QC. This section 5.11 will: now be performed during Part II when the skid is set up in a field condition mode.

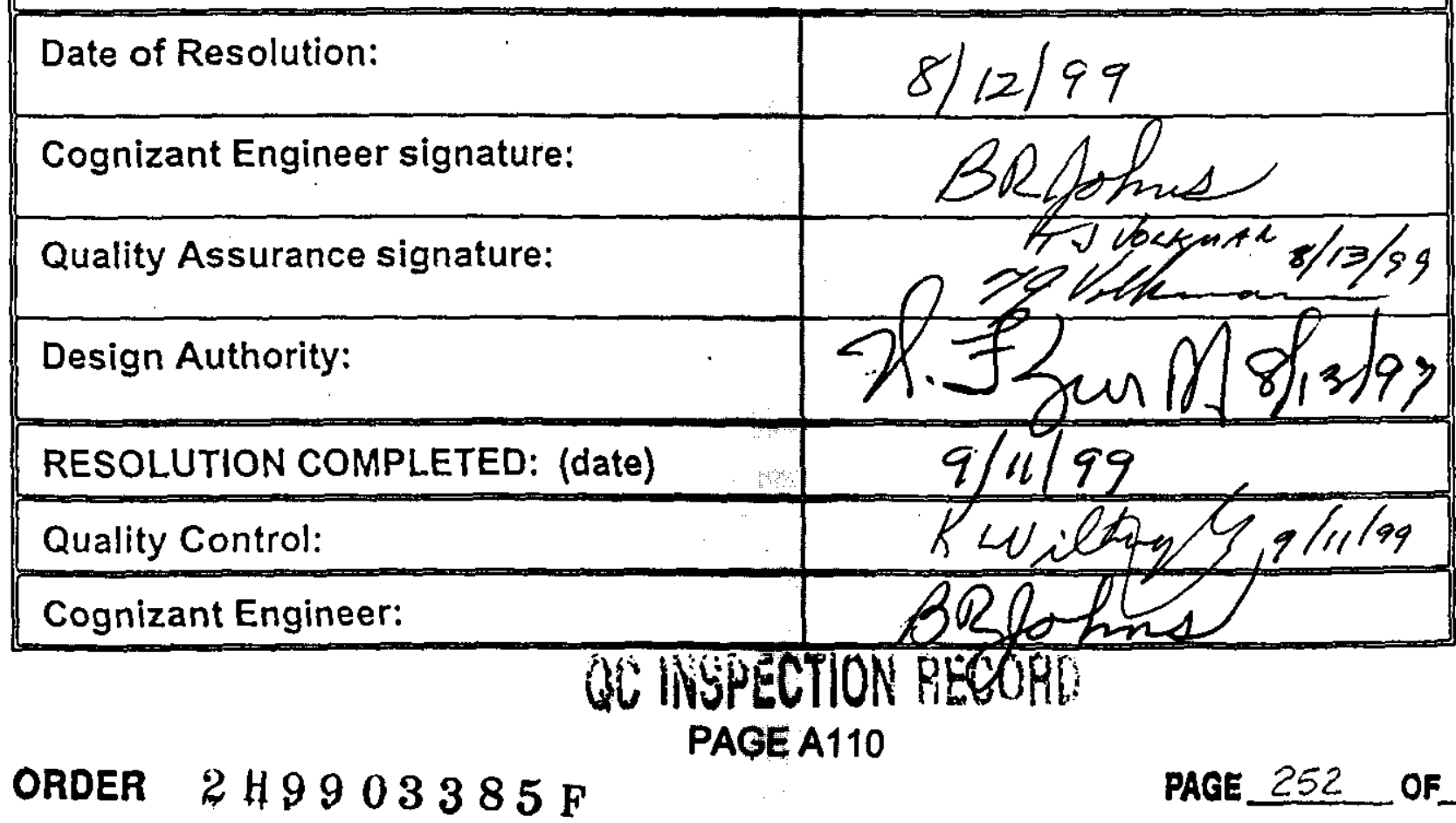

WORK ORDER $2 H 9903385 \mathrm{~F}$

PAGE 252 OF 
HNF-4277

ACCEPTANCE TEST PROCEDURE EXCEPTION RECORD

This page may be reproduced as necessary.

\begin{tabular}{|l|l|l|}
\hline ATP step number: 5.12 .10 & ATP Exception Log Number 20 \\
\hline
\end{tabular}

Description of Exception: Added instructions to bleed air pressure off air compressor tank and water tank.

Resolution of Exception: Vent valve on the water $\operatorname{tank}$ SALW-V-6037K is to be opened to bleed pressure off the water tank. Drain valve: SALW-V - $6043 K$ is to be opened to bleed pressure off of the air compressor tan $k_{\text {. }}$ This is done to put the skid in a safe mode for transporting. Date of Resolution:

$$
8 / 12 / 99
$$

Cognizant Engineer signature:

BR Johns Quality Assurance signature:

Design Authority:

RESOLUTION COMPLETED: (date)

X. Jun 168123199

Quality Control:

$8 / 16 / 99$

Cognizant Engineer:

R Going 8/13/99

OC MSPPECTION dECOR

PAGE A111

PAGE 253 OF

WORK ORDER $2 \mathrm{H} 9903385 \mathrm{~F}$ 
HNF-4277

REVISION 0

ACCEPTANCE TEST PROCEDURE EXCEPTION RECORD

This page may be reproduced as necessary.

\begin{tabular}{|l|l|}
\hline ATP step number: Part II Skip and & ATP Exception Log Number 22 \\
Pump setup. & \\
\hline
\end{tabular}

Description of Exception: Need steps to power up and setup valving to start ATP

Resolution of Exception: Add another bullet to the "Skid and Pump Set Up" to perform steps 5.6.1 through 5.6 .6 and steps 5.6.11 through 5.6.40 as part of preregs. for part II of ATP. The stopping points during these steps shall be at the discretion of the test director and or PIC.

\begin{tabular}{|l|c|}
\hline Date of Resolution: & $9 / 8 / 99$ \\
\hline Cognizant Engineer signature: & BRfolhos \\
\hline Quality Assurance signature: & \\
\hline Design Authority: & \\
\hline RESOLUTION COMPLETED: (date) & \\
\hline Quality Assurance: & \\
\hline Cognizant Engineer: & \\
\hline
\end{tabular}

PAGE A112 
INF -4277

REVISION 0

ACCEPTANCE TEST PROCEDURE EXCEPTION RECORD

This page may be reproduced as necessary.

\begin{tabular}{|l|l|}
\hline ATP step number: 5.13 .34 & ATP Exception Log Number 23 \\
\hline
\end{tabular}

Description of Exception: PS -1 pressure switch not functionicig properly. Low pressure switch closed when should be open. High pressure tripping at 120 p sig instead of 140 prig.

Resolution of Exception: Recalibrate or replace and calibrate replacement pressure switch. Step 5.13 .36 allows software forces at discretion of engineer. Force out pressure switch inputs to allow pump to start. Give caution to operators to shutdown pump if pressure gets to 130 s sig, for pump protection.

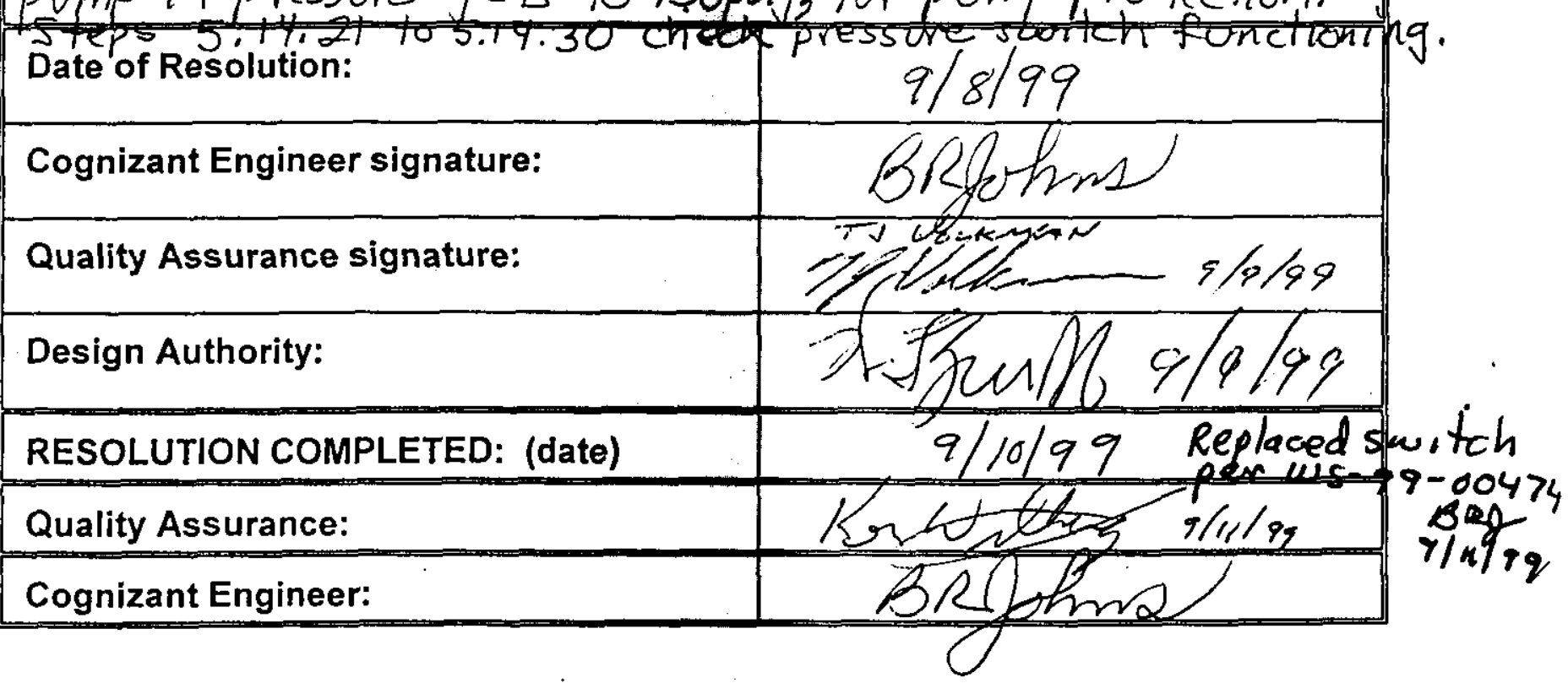

PAGE A113 
HNF-4277

REVISION 0

ACCEPTANCE TEST PROCEDURE EXCEPTION RECORD

This page may be reproduced as necessary.

\begin{tabular}{|l|l|}
\hline ATP step number: 5.14 .51 & ATP Exception Log Number 24 \\
\hline
\end{tabular}

Description of Exception: Need alarm acknowledge step to see alarm 39. The alarm 39 window is preceded by the alarm 12 window for pump shutdown.

Resolution of Exception: Add step immediately a fer step 5.14.51 to acknowledge alarms. This will allow window 39 alarm to be seen during the acknowledging process.

\begin{tabular}{|l|l|}
\hline Date of Resolution: & $9 / 8 / 99$ \\
\hline Cognizant Engineer signature: & \\
\hline Quality Assurance signature: & \\
\hline Design Authority: & \\
\hline RESOLUTION COMPLETED: (date) & \\
\hline Quality Assurance: & \\
\hline Cognizant Engineer: & \\
\hline
\end{tabular}

PAGE A114 
HNF-4277

REVISION 0

ACCEPTANCE TEST PROCEDURE EXCEPTION RECORD

This page may be reproduced as necessary.

\begin{tabular}{|l|l|}
\hline ATP step number: $5.15,10$ & ATP Exception Log Number 25 \\
\hline Description of Exception: SALW-PI- $6005 \mathrm{~K}$ goes to \\
\hline
\end{tabular}

zero after alarm occurs. On second time through, SALW-PI-6005K read 3 prig just immediately to the alarm trip.

Resolution of Exception: After discussion with the design authority, Bill Zuroff, the gauge needs to be read at the instance the trip occurs in order to see the 2 to 4 pig reading required. (Note: future ATP's may reed to clarify this step to rote the pressure on SALW-PI-6005* immediately as the trip occurs, )

\begin{tabular}{|l|l|}
\hline Date of Resolution: & $9 / 9 / 99$ \\
\hline Cognizant Engineer signature: & \\
\hline Quality Assurance signature: & \\
\hline Design Authority: & \\
\hline RESOLUTION COMPLETED: (date) & \\
\hline Quality Assurance: & \\
\hline Cognizant Engineer: & \\
\hline
\end{tabular}

PAGE 1115 


\section{ACCEPTANCE TEST PROCEDURE EXCEPTION RECORD}

This page may be reproduced as necessary.

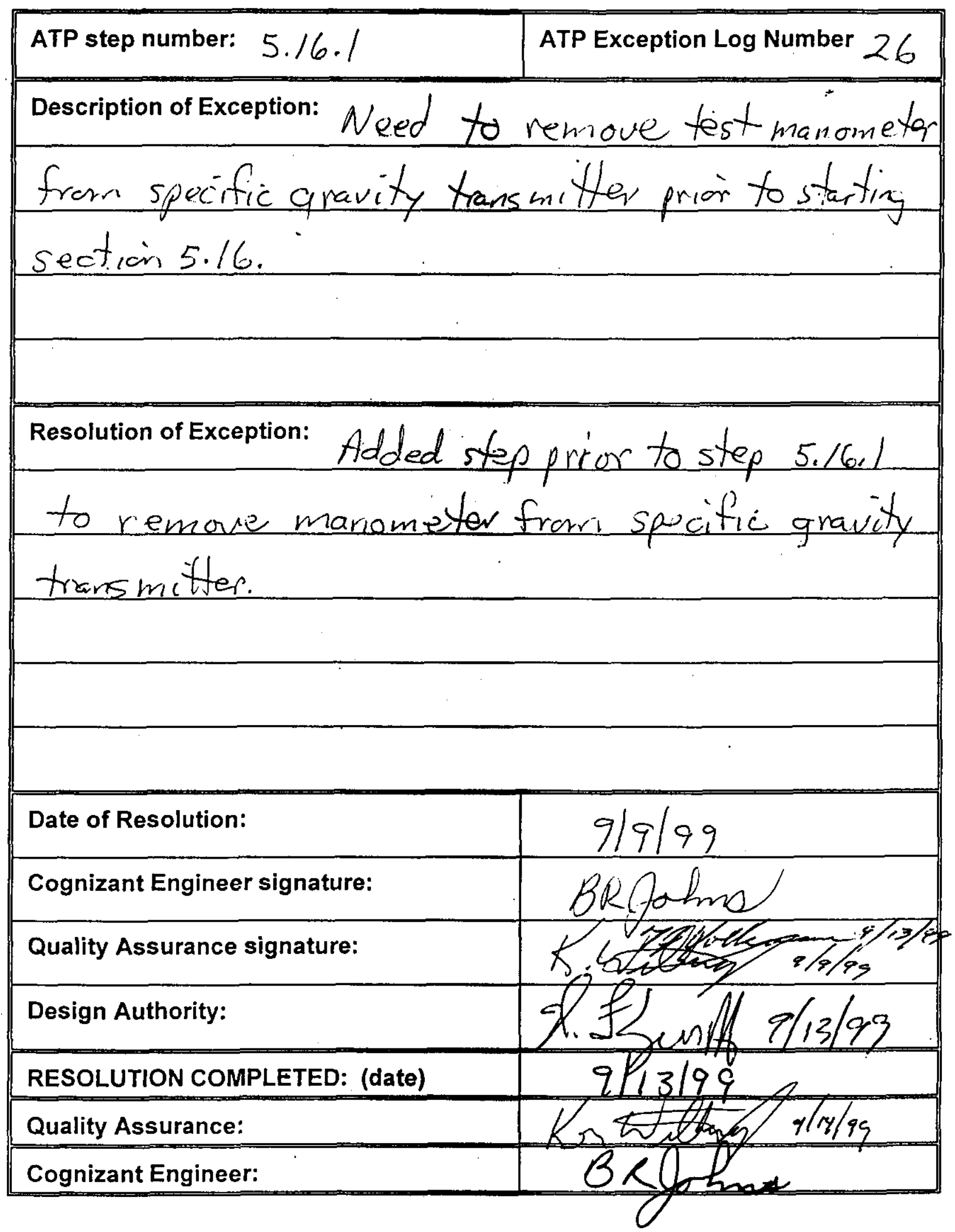


HNF-4277

REVISION 0

ACCEPTANCE TEST PROCEDURE EXCEPTION RECORD

This page may be reproduced as necessary.

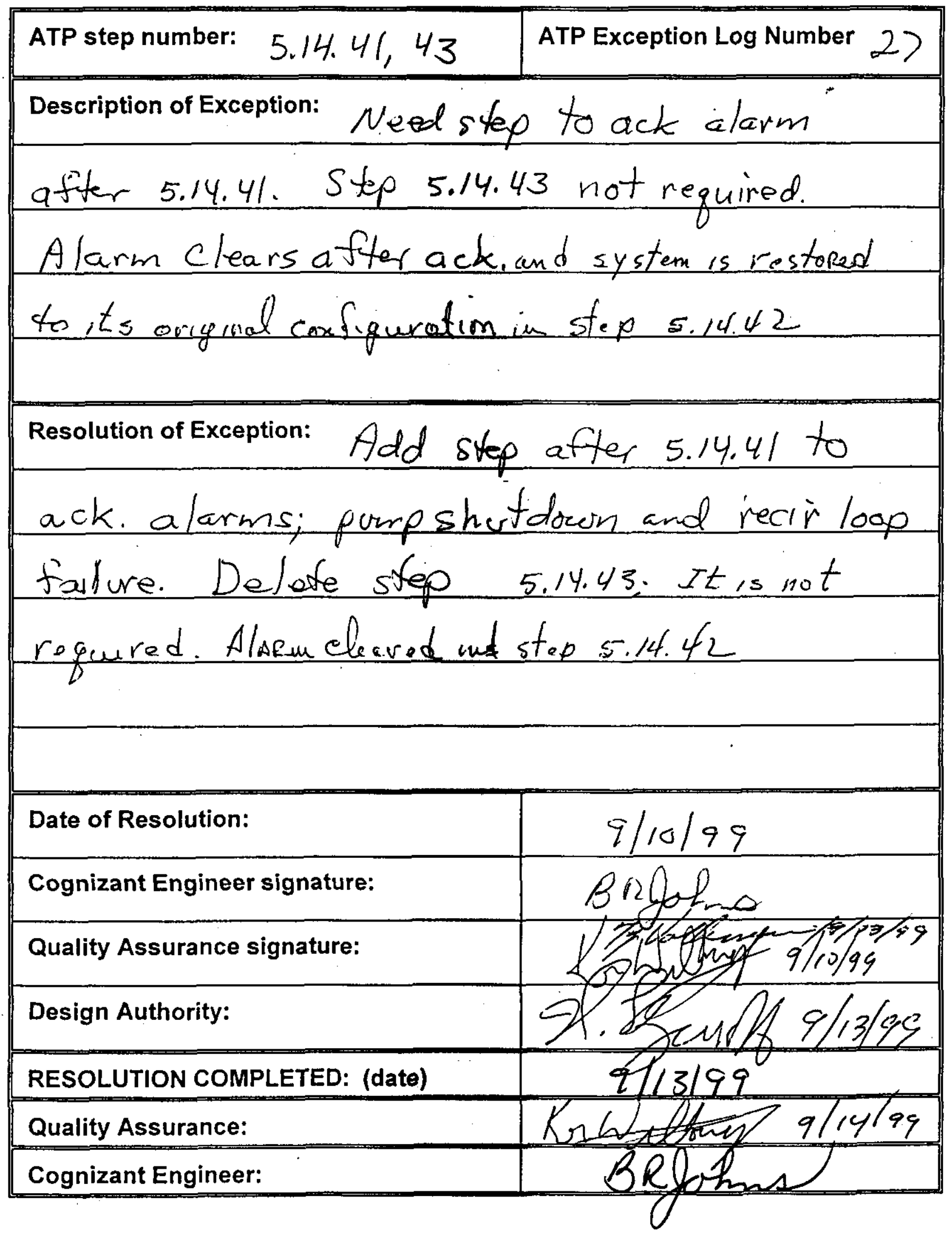

PAGE A117 


\section{ACCEPTANCE TEST PROCEDURE EXCEPTION RECORD}

This page may be reproduced as necessary.

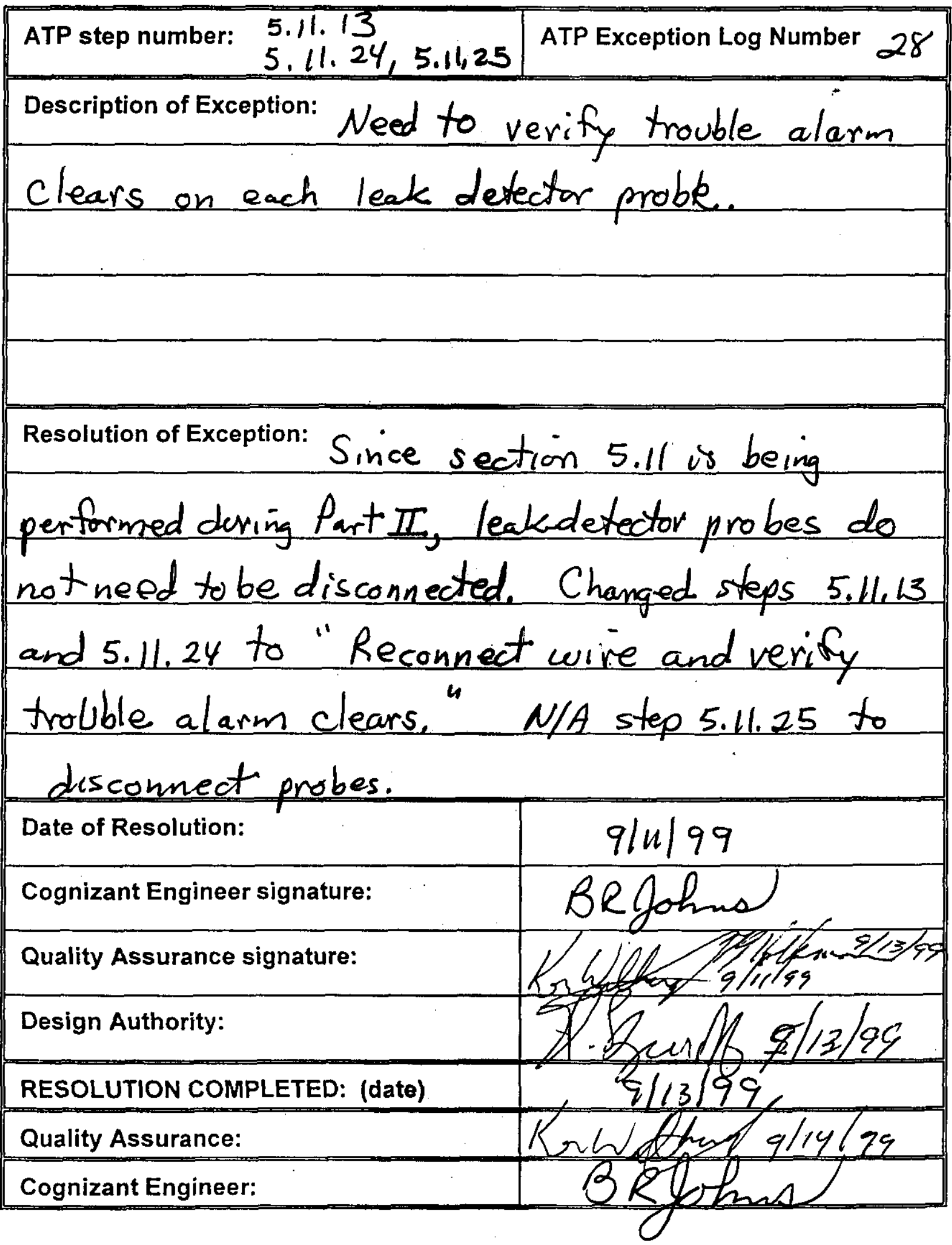


NF -4277

REVISION 0

PROCEDURE PERFORMER SIGNATURE SHEET

All personnel who will be performing, initialing and signing the procedure shall enter their printed name, signature and initials below.

NAME (PRINT)

P.J. ELMENDORF

BD. FOREMAN

D. Gar w

IR Harris

BR Johns

K.W Wr2lougs8,

B.thckman

mo Johnson

M R KOCH
SIGNATURE

Po Glmundof

及. 7 m

$D$ D

QR Harris

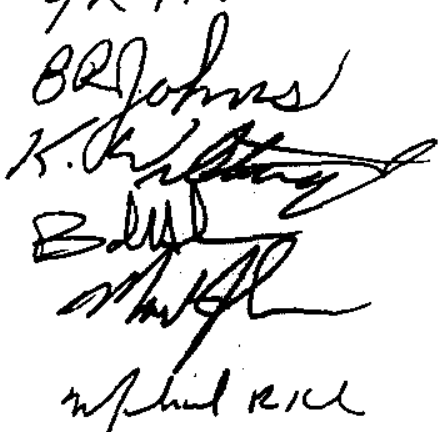

INITIALS

PIE

307

QR

And

Bit

ma

med

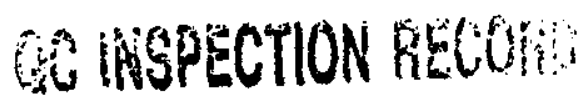

WORK ORDER

2 H 9903385 F

PAGE A119

PAGE _227 OF 
HNF-4277

REVISION 0

ACCEPTANCE TEST PROCEDURE ACCEPTANCE RECORD

This Acceptance Test Procedure has been completed and the results, including red-line changes, exceptions, and exception resolutions, have been reviewed for compliance with the intent of the Purpose (Section 1.0). The test results are accepted by the undersigned:

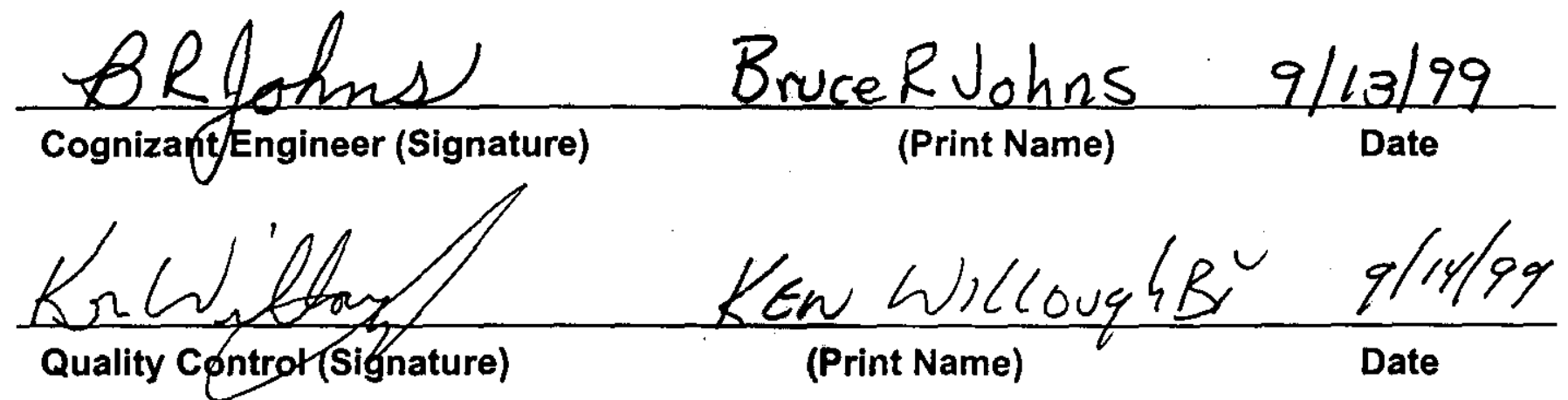

MO MAPECTION BELOW

WORK ORDER

$2 \mathrm{H} 9903385 \mathrm{~F}$

PAGE A120

PAGE 226 OF 
Send to: Bruce Johns $57-24$

HNF-4277

REVISION 0

NEC INSPECTION REPORT

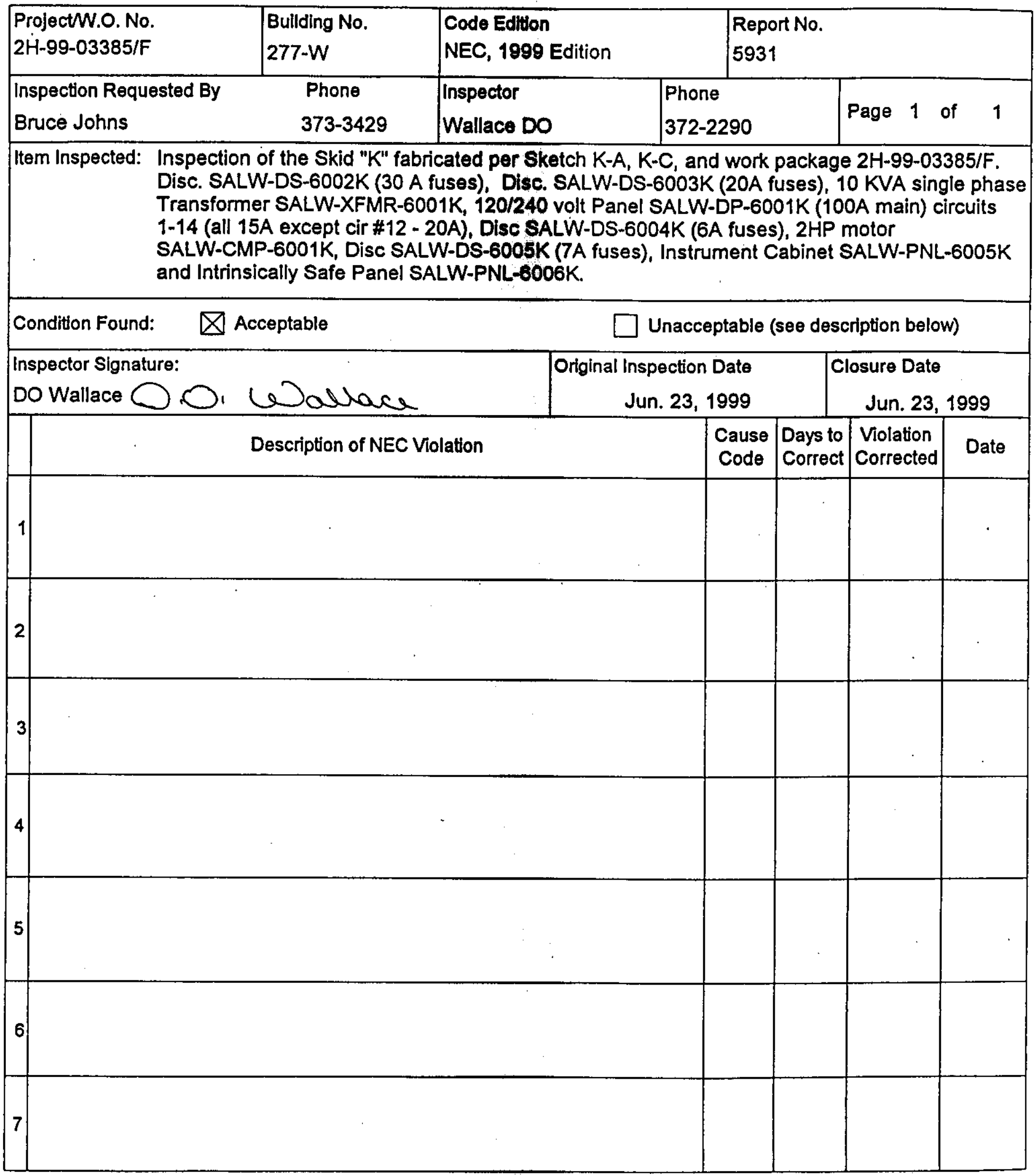

Electrical service will be discontinued for the equipment or facility identified if violations are not corrected within time allowed by the "Days to Correct" column. "Days to Correct" starts with the original inspection date. For concerns regarding this, call the Chief Electrical Engineer at 376-6347. 
TPI WO NO: WT-99-

( 1 Hrs)

\begin{tabular}{|c|c|c|c|c|c|c|}
\hline 1 & $\begin{array}{l}\text { Date Inspected } \\
6 / 22 / 1999\end{array}$ & $\begin{array}{l}\text { Cert Exp } \\
06 / 2001\end{array}$ & $\begin{array}{l}\text { Cert. Posted } \\
{[\mathrm{X}] \text { Yes [] No }}\end{array}$ & $\begin{array}{l}\text { Owner No } \\
\text { SKID-K }\end{array}$ & $\begin{array}{l}\text { Jurisdiction No } \\
\text { TPI-WT-135 }\end{array}$ & $\begin{array}{l}\text { National Board / Other } \\
\text { NB-37811L }\end{array}$ \\
\hline 2 & \multicolumn{2}{|c|}{$\begin{array}{l}\text { Owner: DEPARTMENT } \\
\text { OF ENERGY (RL) }\end{array}$} & \multicolumn{2}{|c|}{$\begin{array}{l}\text { Owner Address: HANFORD, } \\
\text { RICHLAND, WA } 99352\end{array}$} & \multicolumn{2}{|c|}{$\begin{array}{l}\text { Kind of Inspection } \\
\text { [] Int'] [X]Ext } \\
\text { [ [X]Yes [ [ ]No }\end{array}$} \\
\hline 3 & \multicolumn{3}{|c|}{$\begin{array}{l}\text { User Name: (LMHC) } \\
\text { LOCKHEED MARTIN HANTORD CORP. }\end{array}$} & \multicolumn{2}{|c|}{$\begin{array}{l}\text { User Location: } 200 \cdot W \\
\text { Will be at: U FARM }\end{array}$} & $\begin{array}{l}\text { Specific Location: } \\
\text { SALT WELL U-103 }\end{array}$ \\
\hline 4 & $\begin{array}{l}\text { Type } \\
\text { [X]AIR TANK }\end{array}$ & []WATE & R TANK & Other & $\begin{array}{l}\text { Year Built } \\
1998\end{array}$ & $\begin{array}{l}\text { Manufacture: } \\
\text { BRUNNER ENG }\end{array}$ \\
\hline \multirow[t]{2}{*}{5} & $\begin{array}{l}\text { Use: Storage } \\
{[\mathrm{X}] \text { Receiver }}\end{array}$ & []Process & $\begin{array}{l}\text { Heat } \\
\text { []Exchange }\end{array}$ & [ ]Other & $\begin{array}{l}\text { Size: } \\
14^{\prime \prime} \times 20^{\prime \prime}\end{array}$ & $\begin{array}{l}\text { Inspection opening size: } \\
\text { 2" PLUGS }\end{array}$ \\
\hline & \multicolumn{4}{|c|}{ Pressure Gauge Tested [ ]Yes [X]NQ. } & \multicolumn{2}{|c|}{ Hydro Test: [ ]Yes [X]No } \\
\hline 6 & \multicolumn{2}{|c|}{$\begin{array}{l}\text { Pressure Allowed (MÁWP) } \\
\text { This Inspection: } 200 \text { PSIG }\end{array}$} & \multicolumn{2}{|c|}{$\begin{array}{l}\text { Safety-Relief Valve: } \\
\text { Stamped PSI: } 125^{\circ}\end{array}$} & \multicolumn{2}{|c|}{$\begin{array}{ll}\text { Valve: SALW-PRV-6004Kं How Tested } \\
1 / 2^{\prime \prime}, 269 \text { CFM } & \text { NEW } \\
\end{array}$} \\
\hline \multirow[t]{3}{*}{7} & \multicolumn{6}{|c|}{ Certificate may be issued? [X ] Yes } \\
\hline & \multicolumn{5}{|c|}{ 7a. INSPECTION STATUS: [X] Passed } & [] Reinspect \\
\hline & \multicolumn{4}{|c|}{ 7b. VESSEL STATUS: $[\mathrm{X}]$ Active } & [ ] E & [] Removed \\
\hline
\end{tabular}

Inspected at 277-W Fabrication. Shop during final assembly. Scheduled to be located at Tank U-103.

8a: Internal Inspection not done or required this inspection..

8b: External Inspection shows no dents, damage, leakage, corrosion or excess vibration. Pressure guage: Installed \& Proper Bottom drain: Installed \& Suitable Safety-Relief Valve Seal was intact with no evidence of damage or tampering

9 REQUIREMENTS/RECOMMENDATIONS: The following items are to be corrected:

1. None this inspection

10 Name of Facility Contact to whom requirements were explained: Bruce Johns Tel: $373-3429$ S7-24

Copies to: David Saueressig Tel: 373-0183 S7-20, Mike Koch Tel: 373-2699 S7-24

I hereby Certify this is a true report of my inspection

Signature of Ipspector

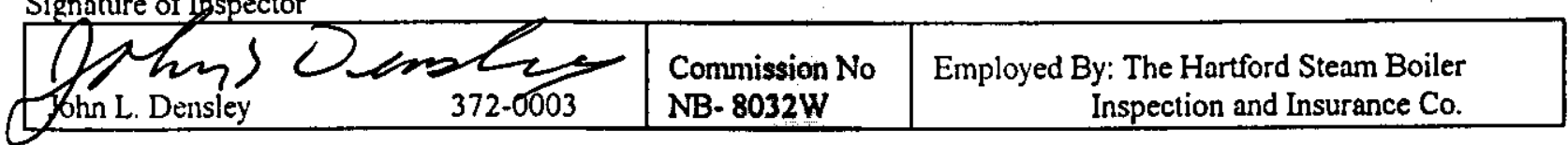

TPI-WT-135.doc 
TPI WO NO: WT-99( 1 Hrs)

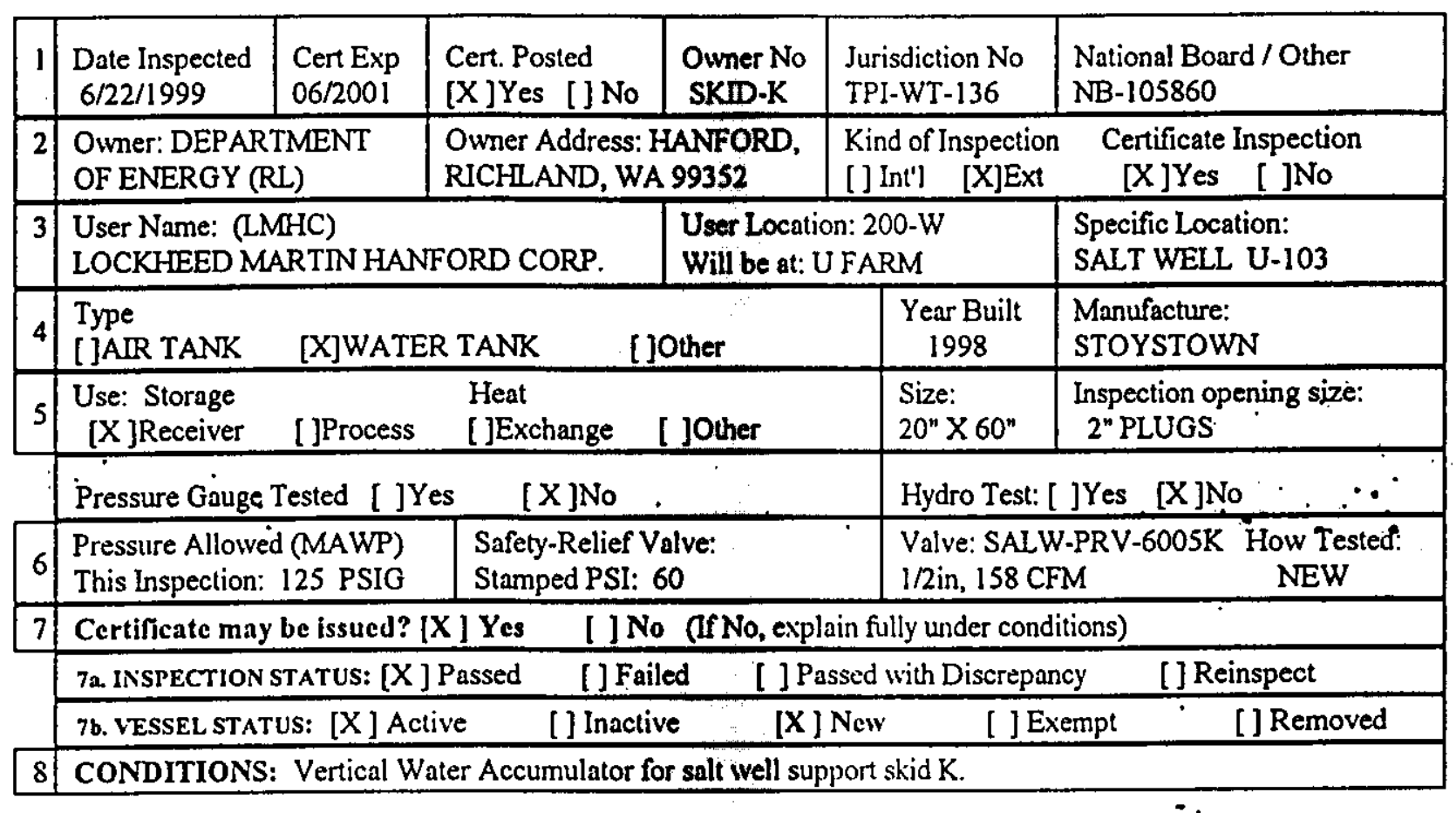

Inspected at 277-W Fabrication Shop during final assembly. Scheduled to be located at Tank U-103.

8a: Internal Inspection not done or required this inspection..

8b: External Inspection shows no dents, damage, leakage, corrosion or excess vibration.

Pressure guage: Installed \& Proper Bottom drain: Installed \& Suitable

Safety-Relief Valve Seal was intact with no evidence of damage or tampering

\begin{tabular}{|l|l}
9 & REQUIREMENTS/RECOMMENDATIONS: The following items are to be corrected:
\end{tabular}

1. None this inspection

10 Name of Facility Contact to whom requirements were explained: Bruce Johns Tel: $373-3429$ S7-24 Copies to: David Saueressig Tel: 373-0183 S7-20, Mike Koch Tel: 373-2699 $\quad$ S7-24

I hereby Certify this is a true report of my inspection

Siggature of Inspector

\begin{tabular}{|l|l|l|l|}
\hline John L. Densley & $\begin{array}{l}\text { Commission No } \\
\text { NB- 8032W }\end{array}$ & $\begin{array}{c}\text { Employed By: The Hartford Steam Boiler } \\
\text { Inspection and Insurance Co. }\end{array}$ \\
\hline
\end{tabular}

TPI-WT-136.doc 